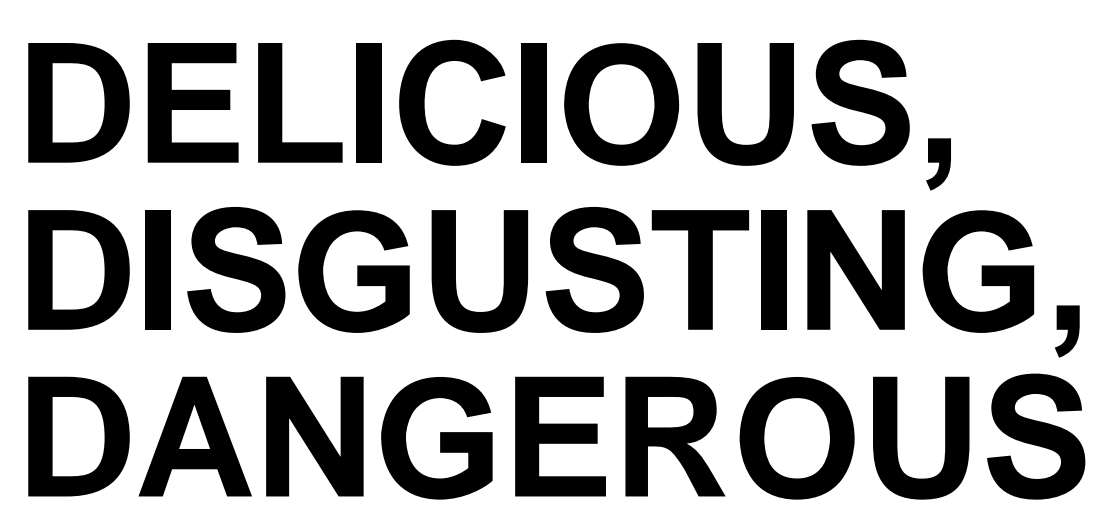

\title{
Eating in a Time of Food Price Volatility
}

Year 3 findings from the Life in a Time of Food Price Volatility Study

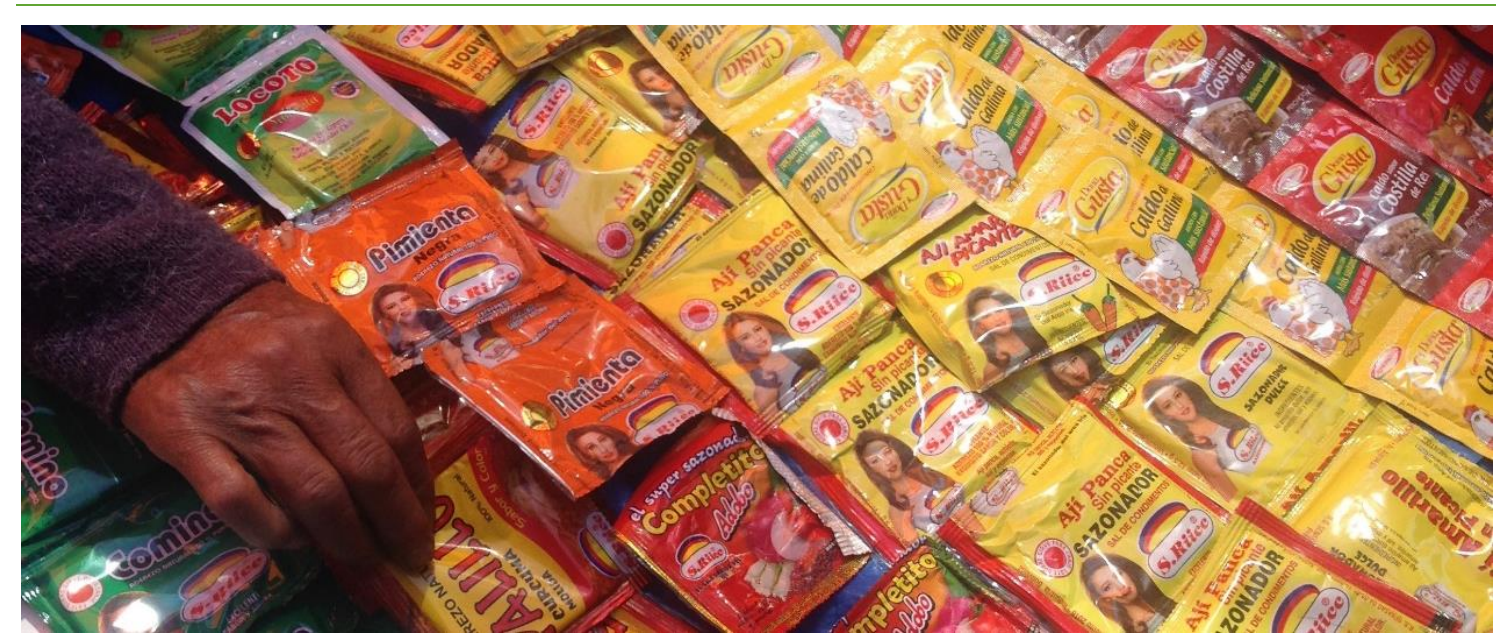

Sachets of flavouring, Cochabamba, Bolivia. Credit: Alexandra Wanjiku Kelbert 2014

NAOMI HOSSAIN

RESEARCH FELLOW, INSTITUTE OF DEVELOPMENT STUDIES

RICHARD KING

POLICY RESEARCH ADVISER, OXFAM

ALEXANDRA WANJIKU KELBERT

RESEARCHER, INSTITUTE OF DEVELOPMENT STUDIES

PATTA SCOTT-VILLIERS

RESEARCH FELLOW, INSTITUTE OF DEVELOPMENT STUDIES

NICK CHISHOLM

SENIOR LECTURER, UNIVERSITY COLLEGE CORK

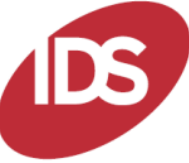


The third year results of the study Life in a Time of Food Price Volatility uncover the realities of what people on low and precarious incomes are eating. For the consumer, there are undeniable benefits from the integration of world food trade: more stable supply, wider choice. Changes in food habits mean people are finding new ways to enjoy food and new foods to enjoy, often with greater convenience and ease. There is much to savour in the eating landscape as new markets for purchased and prepared foods open up. But the loss of control this brings has detrimental impacts on wellbeing. Most people feel they understand little about how new foods affect their health and nutrition; knowledge that they had accrued over generations and longer with respect to their customary cuisines. People have real worries about a new culture of fast food and fake food; they worry about additives, nourishment and food hygiene, and they feel that governments do too little to protect them from the risks.

Further information and reports from previous years about this project are available at:

www.ids.ac.uk/lifeinatime www.oxfam.org.uk/foodprices 


\section{CONTENTS}

Glossary of food terms $\quad 5$

$\begin{array}{ll}\text { Acronyms } & 6\end{array}$

$\begin{array}{ll}\text { EXECUTIVE SUMMARY } & 7\end{array}$

1 INTRODUCTION 8

SECTION 1: THE WAY WE EAT NOW $\quad 10$

2 ANXIOUS CONSUMERS

3 CHANGING FOOD CULTURES

3.1 Traditions in decline 13

3.2 The novelty and pleasure of foreign foods 15

4 WHO EATS WHAT, WHERE, WHEN, WITH WHOM AND WHY? 18

4.1 Class and the cost of food 18

4.2 Gender and generation 20

$\begin{array}{ll}4.3 \text { Family and care } & 27\end{array}$

$5 \quad$ BAD FOOD 31

5.1 What are people worrying about? 31

5.2 Food production $\quad 34$

$\begin{array}{ll}5.3 \text { Additives } & 35\end{array}$

5.4 Hygiene $\quad 35$

5.5 Health and nutrition $\quad 36$

5.6 Changing relationships 36

$\begin{array}{ll}5.7 \text { Who is protecting us against bad food? } & 37\end{array}$

5.8 What do people think should be done? 38

SECTION 2: FOOD PRICE MOVEMENTS IN $2014 \quad 40$

6 WORLD FOOD PRICES 40

6.1 Why have prices fallen? 43

6.2 Policy developments 44

7 NATIONAL FOOD PRICES $\quad \mathbf{4 5}$

7.1 Bangladesh $\quad 45$

$\begin{array}{ll}7.2 \text { Bolivia } & 46\end{array}$

7.3 Burkina Faso $\quad 46$

$\begin{array}{ll}7.4 \text { Ethiopia } & 47\end{array}$

$\begin{array}{ll}7.5 \text { Guatemala } & 48\end{array}$

$\begin{array}{ll}7.6 \text { Indonesia } & 48\end{array}$

$\begin{array}{ll}7.7 \text { Kenya } & 49\end{array}$

$\begin{array}{ll}7.8 \text { Pakistan } & 50\end{array}$

$\begin{array}{ll}7.9 \text { Vietnam } & 51\end{array}$ 
8 SUMMARY 53

9 CONCLUSIONS

9.1 The link to food price volatility 56

9.2 Control and knowledge as food cultures change 57

10 RECOMMENDATIONS

NOTES

$\begin{array}{ll}\text { BIBLIOGRAPHY } & 64\end{array}$

$\begin{array}{lr}\text { ACKNOWLEDGEMENTS } & 69\end{array}$

\section{Tables}

Table 1: Disgusting and dangerous food 32

Table 2: Cumulative impact of main staple food price changes on cost of the food basket, relative to previous quarter food basket, relative to baseline

\section{Boxes}

Box 1 Project overview

Box 2 Methods

\section{Figures}

Figure 1: Research locations 9

Figure 2: Food price indices decline markedly in 2014

Figure 3: Most food price indices fell in 2014, with the exception of meat and sugar

Figure 4: World staples and crude oil prices fell sharply for most of 2014, mixed picture for rice

Figure 5: Real and nominal food prices remain high in historical terms, but no longer dramatically so

Figure 6: Cereal prices projected to fall over the medium term. Prices expressed in nominal (left) and real terms (right)

Figure 7: Improving stock levels and stock-to-use ratios for staple crops provide a buffer against future shocks

Figure 8: Food and general consumer price inflation 2012-2014 


\section{Glossary of food terms}

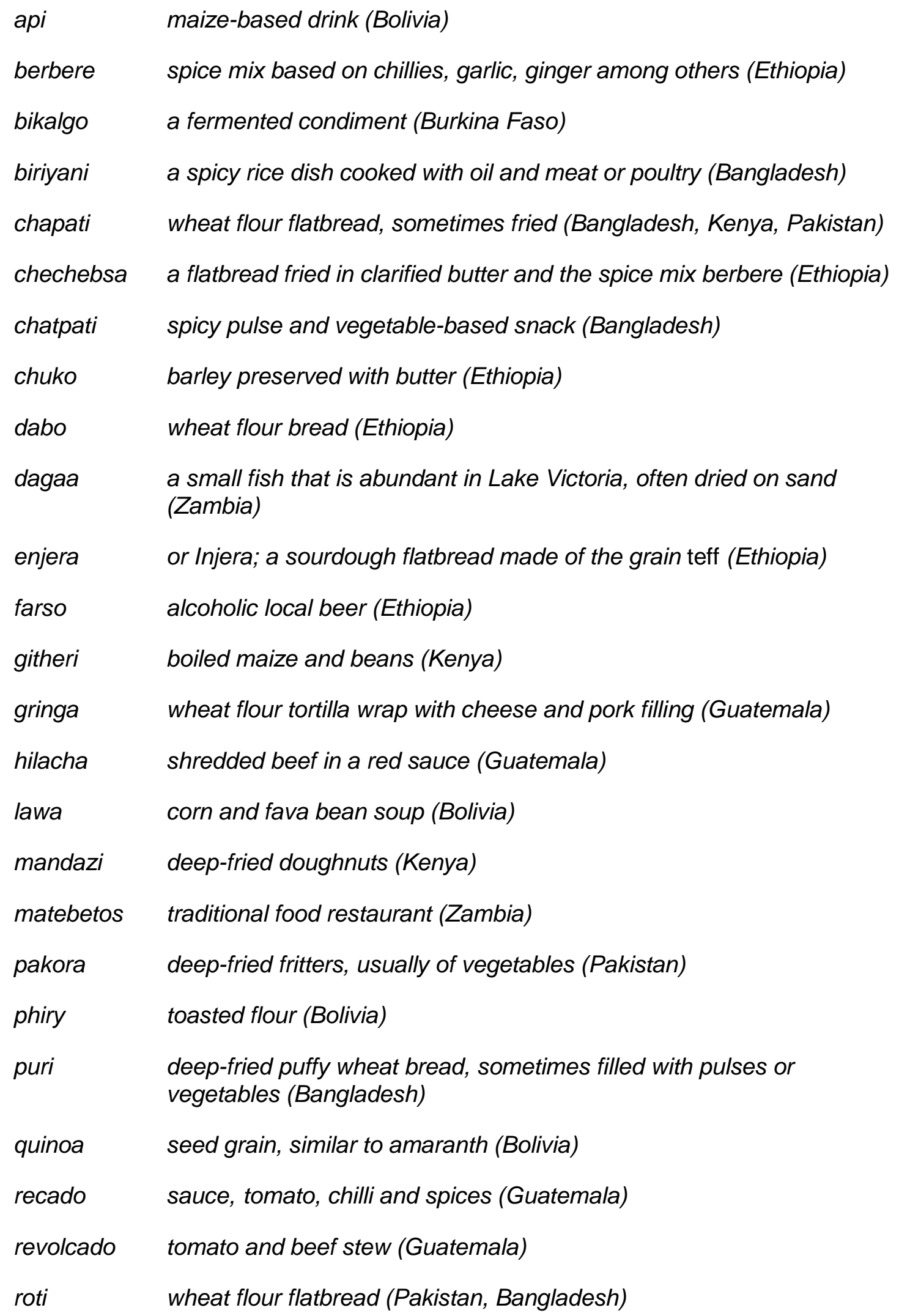




$\begin{array}{ll}\text { samosa } & \begin{array}{l}\text { fried pastry filled with spiced vegetables or meat (Bangladesh, } \\ \text { Ethiopia, Kenya, Pakistan, Zambia) }\end{array} \\ \text { shingara } & \begin{array}{l}\text { similar to samosa, but usually made with shortcrust pastry } \\ \text { (Bangladesh) }\end{array} \\ \text { shiro wat } & \text { spicy powdered chickpea stew (Ethiopia) } \\ \text { shutki } & \text { dried fish relish (Bangladesh) } \\ \text { teff } & \text { seed grain used to make enjera (Ethiopia) } \\ \text { tô } & \text { sour millet/sorghum dough (Burkina Faso) } \\ \text { torosho } & \text { leavened corn bread (Ethiopia) } \\ \text { ugali } & \text { maize meal dough (Kenya, Zambia) }\end{array}$

\section{Acronyms}

$\begin{array}{ll}\text { AMIS } & \text { Agricultural Market Information System } \\ \text { CPI } & \text { Consumer Price Index } \\ \text { FAO } & \text { Food and Agriculture Organization } \\ \text { GIEWS } & \text { Global Information and Early Warning System } \\ \text { IFPRI } & \text { International Food Policy Research Institute } \\ \text { IPC } & \text { Integrated Food Security Phase Classification } \\ \text { JCME } & \text { Joint Child Malnutrition Estimates } \\ \text { m.t. } & \text { metric tonne } \\ \text { NGO } & \text { non-governmental organisation } \\ \text { SOFI } & \text { State of Food Insecurity in the World } \\ \text { UNICEF } & \text { United Nations Children's Fund } \\ \text { WFP } & \text { World Food Programme } \\ \text { WHO } & \text { World Health Organization }\end{array}$




\section{EXECUTIVE SUMMARY}

Each year, the Life in a Time of Food Price Volatility research project tracks global, national and local food prices and their effects on everyday life, and selects a special topic for focused research. Delicious, Disgusting, Dangerous: Eating in a Time of Food Price Volatility is the third synthesis report, and this year it turns the spotlight on to changes in diet. We ask about what people on low and precarious incomes are eating now and how they are responding to the increasing commodification of food. We explore how these changes are linked to adjustments in work, residence and home life. What do they like and dislike about the changes they have made? What worries them and what are they doing to protect themselves from the risks they think they are facing in their new diets? And, finally, what are governments and other authorities doing to protect people from the risks of food that may be delicious, but possibly dangerous or disgusting?

Food price movements in the ten countries during 2014 generally displayed lower levels of volatility than in recent years, but there continue to be often quite marked seasonal changes, largely linked with the level of national food availability. The generally downward trend in international cereal prices was not uniformly mirrored in each of the countries, although some countries, for example Bolivia, Burkina Faso and Vietnam, did mostly experience falling prices. In all countries for which data were available, however, annual food inflation and general inflation continue at levels (commonly between 6-8 per cent) that create hardship for market-dependent low-income households. In all countries, the cost of the minimum food basket continues to be well above the five-year average, which reinforces the view that the struggle to cope with high food prices is a long-term reality, which has not diminished just because food price increases have recently been less dramatic. The need for effective action to enhance resilience and reduce the negative effects of food price changes is as pressing as ever.

There has been a marked change in what people are eating, directly and indirectly influenced by the effects of food price volatility. Even in places where malnourishment is common we find considerations of time, convenience, novelty, taste, safety and status competing with objective assessments of nourishment in shaping what food people choose to buy. Increasingly people evaluate their consumption choices in terms of value and that value may have many dimensions that are not just about the nutritional quality of food.

While people generally perceive wider availability of different foodstuffs as a positive sign of their community's economic development and social progress, fears about nutritional and health consequences of changing diets are widespread. As food preparation and consumption increasingly occurs outside the household, concerns about dubious ingredients and unsanitary conditions abound.

People are feeling a loss of control over what they are eating. Concerns about the content of foods available on the market are widespread. With this in mind, governments and donors need to consider three courses of action:

1. Preserving and promoting customary food cultures and providing trustworthy information about new food choices;

2. Building public health regimes that promote nutrition and question fortification when it is a poor substitute for better quality food;

3. Upgrading food safety regimes so they are seen to tackle issues of unhygienic and dangerous foods. 


\section{INTRODUCTION}

Delicious, Disgusting, Dangerous reports the third year results from the Life in a Time of Food Price Volatility research project. It follows on from the situations reported in the first and second years in Squeezed (Hossain, King and Kelbert 2013) and Help Yourself! (King et al. 2014). More details of the overall project approach, research sites and methodology can be found in Squeezed.

Changes in food prices are significant events in people's lives. With funding from UK Aid and Irish Aid, in 2012 a four-year project began to track the impact of changes on everyday life emerging from food price volatility in ten countries and 23 sites. The social costs of managing change when food prices rise or are volatile are often invisible to policymakers. Nutritional or poverty measures often suggest people have coped well and are 'resilient', because they neglect the costs of coping and resilience - more time and effort to feed and look after people; non-monetary effects on family, social or gender relations; mental health costs; lower quality of life; feeling forced to eat 'foreign' or 'bad' food. These issues tend to be neglected in impact studies, but they matter a great deal to those affected. People's responses to local food price volatilities have been part of a process of rapid social change, the mechanisms of which are poorly understood.

Spanning the period 2012-15, Life in a Time of Food Price Volatility aims to study how price changes affect the everyday life of people on low or precarious incomes, looking at what is happening with paid work, unpaid care work and family responsibilities, relationships and the resources with which people cope. The collective of researchers works in ten urban/periurban and thirteen rural locations across ten low- to middle-income countries (see Box 1).

The first half of this report for Year 3 summarises the findings of the 'special' topic for this year: changing food habits.

Here we focus on the shift to processed and pre-prepared foods linked to rising food prices and on people's concerns about food health and safety issues. In previous rounds of research we were struck by the rapid transformations in people's diets, away from home-prepared, local and traditional foods towards more 'foreign' and convenience foods. We wanted to understand whether the sharp changes in food prices over the period since 2007 have influenced the pace or nature of this transition, as well as how it was being experienced in the patterns of daily life, including its effects on wellbeing and development. To what extent do these changes reflect ongoing shifts in cultural preferences and aspirations, and where they are driven by pragmatic concerns around the time and monetary costs of food preparation?

In keeping with the remit to monitor changes in food prices, the second half of this report focuses on what has happened with global and national food prices in the past year. It shows that world food prices further declined throughout much of 2014, as a result of abundant stocks and harvests unencumbered by dramatic weather events. Local prices of many basic foods in the ten focus countries displayed lower levels of volatility than in recent years, but there continue to be often quite marked seasonal changes, largely linked with the level of national food availability. 


\section{Box 1: Project overview}

Spanning the period 2012-15, Life in a Time of Food Price Volatility aims to study how price changes affect the everyday lives of people on low or precarious in-comes, looking at what is happening with paid work, unpaid care work or family responsibilities, how relationships are affected and the resources with which people cope. The collective of researchers works in ten urban/peri-urban and 13 rural locations across ten low- to middle-income countries.

Each year a synthesis report has outlined the learning across these ten countries. These and other outputs are available online (www.oxfam.org.uk/foodprices).

Figure 1: Research locations

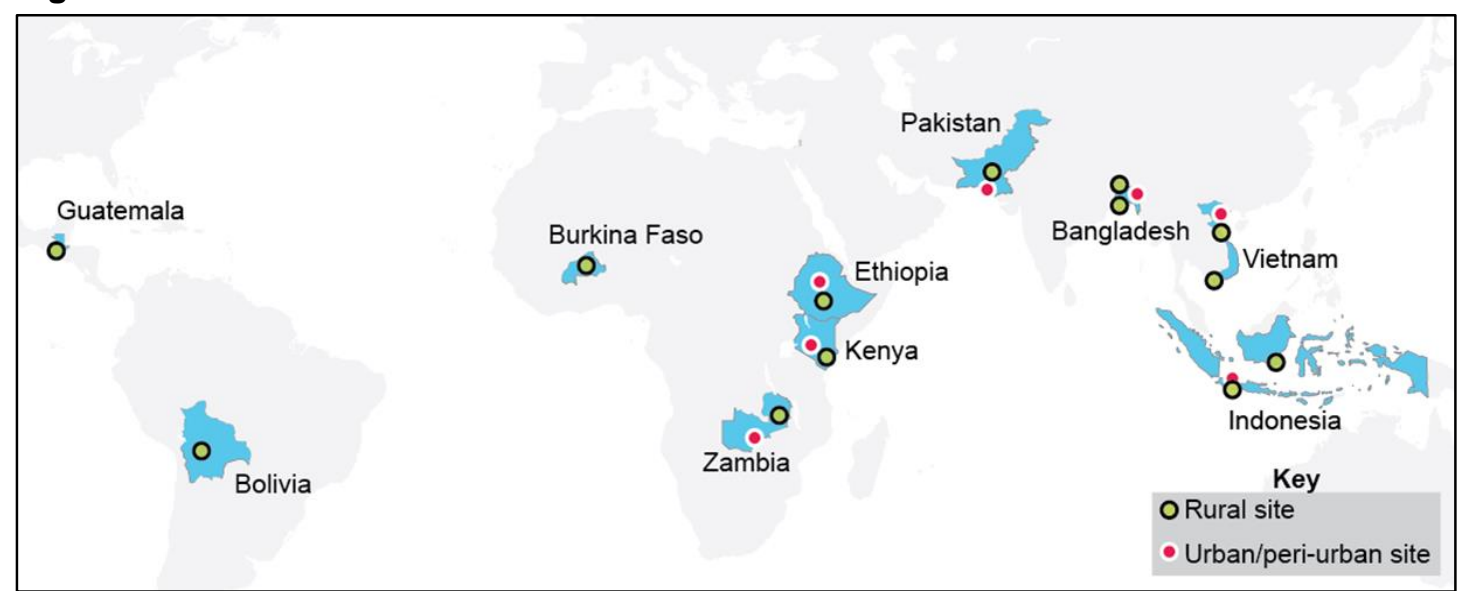

\section{Box 2: Methods}

Life in a Time of Food Price Volatility has three component activities:

1. Food security indicator tracking aimed at generating a picture of what has been happening to food security and food prices.

2. Qualitative research, with short annual visits to groups and households. Eight of the sites have been visited annually since 2009. 2014 was the sixth annual visit. In the remaining 15 sites, research was initiated in 2012. Details of the research sites are available in the Year 1 report (www.oxfam.org.uk/foodprices). In each community, researchers followed at least ten households, conducted five key informant interviews, and held focus group discussions with at least four different social and occupation groups. Other primary and secondary data was also gathered at the community level. In total, around 1,500 people participated in the research each year.

3. Integrated qualitative and quantitative (Q2) analyses of the impacts of food price changes on wellbeing, drawing on nationally representative poverty data for each country.

More details of the overall project methodology are available in Annex 1 in Squeezed, the report on the Year 1 results. 


\section{SECTION 1: THE WAY WE EAT NOW}

This section of the report looks at the findings from our special topic for 2014 on changing food habits, with a focus on the processed and prepared foods people are buying and on their concerns about food health and safety issues.

The way people eat on low and precarious incomes in different parts of the developing world is changing fast. Even outsiders like ourselves could not help but pick up on it. In fact, 1) talk of novel, strange and foreign foods, 2) visible signs that packaged and processed foods are providing newly viable alternatives to customary items and 3) fears about the health and nutrition effects of 'bad' and convenience foods were common and striking enough in earlier rounds of this research in 23 rural and urban sites in ten countries on three continents that we felt compelled to explore how food habits were believed to be changing, why and to what effect. Changes of this nature are part of the global nutrition transition away from cereal and plant-based foods towards fattier, more sugary and in general more 'Western'-style diets (Drewnowski and Popkin 1997), so that even while many people are undernourished, others in the same country, community or even household, may be overweight. ${ }^{1}$ They are also part of the globalisation and industrialisation of food systems. Through a focus on changing food habits we wanted to understand whether the sharp changes in food prices over the period since 2007 has influenced the pace or nature of this transition, as well as how it was being experienced in the patterns of daily life, including its effects on wellbeing and development.

We learned that people recognise that their everyday food habits have been changing in these directions for decades or even longer in some places, as they move away from subsistence farming or on-farm work into urban areas and off-farm wage work. But in places where economies remain mostly agrarian and in some rural and remote settings, these changes have come only in the past few years. Different food cultures appear to have absorbed or resisted change in different ways and to different degrees, depending on what people can afford, what they hold most dear about food cultures and traditional dishes and on messages from the wider culture. What we see, on plates and in cooking pans, on kitchen shelves, in shops, market stalls and street vendor carts and from what people say and show us, is that the changes are not only in what substances people actually put in their mouths, but also in the social and economic organisation of how those items are produced, marketed, procured, prepared and served. Local flavours remain important, but the activities involved in turning goods into food show signs of becoming more homogenous and uniform, integrated within national and international economies, and closely enmeshed within the world food economy (Clapp 2011).

Changes in the food system inevitably influence how people think about eating and the 'food stories' they tell about what they consume (Freidberg 2003). People say that these changes are having impacts on their bodies: their health, energy and ability to flourish and develop. It is clear, too, that the changes influence their collective and individual identities as well as their relationships, particularly within families, but also in how they engage in public spaces like markets, restaurants and workplaces. ${ }^{2}$ What may be less immediately noticeable but equally vital to human wellbeing is the effects on how societies organise the gendered work of care which provides the foundations of human wellbeing: the nature of the work of feeding the family, particularly of nourishing its infant members, thus mutates from one of skilled production - growing, home-processing, preparing and cooking, into one of procurement bargain-hunting, consumer knowledge, creative combinations and shopping skills (see Harris 2014; DeVault 1994). 


\section{ANXIOUS CONSUMERS}

Two broad findings stand out from this year's special theme.

First, that food is increasingly a consumer good, even in low-income developing country communities that sometimes face the stress of empty bellies.

For better or worse, the role of food as essential nourishment is competing with the functions played by its newer marketed forms in offering choice and sensation, saving time, effort and cost, and creating status and identity. People approach the problem of what to eat increasingly from the point of view of consumers seeking value and that value may have many dimensions in the contemporary world that are not just about the nutrients of food. While we know that this is the case in the developed world, we may find it hard to imagine that people at risk in places where hunger persists on a large scale may seek value in the food they consume in more than just basic nutrients, or the calories needed to stay alive. And yet considerations of time, convenience, novelty, taste, safety, nutritional value, status and identity all play some role in shaping what food people choose to buy.

The idea of food as a consumer good is not intended, however, to suggest that these people play a powerful role in food markets by acting as agents that choose on the basis of free will, crafting market supply to their nutritional needs and wants. To assume that would be to ignore the power of prices to constrain choices both in what food to eat and in where to live and how to earn a living. Rising international demand has, in some documented cases, made traditional products too expensive for local buyers. Families moving to urban areas and women taking on more work outside the home mean less time and space to cook, forcing change in food choices. Advertising to children is an established means through which consumer choice is 'constrained' (Kelly et al. 2010). And once habits of calorie-dense fatty sugary food are formed, they provide a steady stream of income for food suppliers (see Lobstein et al. 2015), in quite the same ways that a drug dealer encourages users to become addicted.

A second finding is that changing food habits are both a significant source of anxiety as well as a barometer of wider social change, for better and for worse.

Many people perceive wider availability of different foodstuffs as a positive sign of their community's economic development and social progress. It is pleasurable to have more choices about what we eat and marvellous innovations that make food easier and quicker to prepare. It is handy to be able to send the kids out to get a kebab or a pasty or boil up some instant noodles when you have just got home from work and still have to do the laundry. But fears about food safety and hygiene and its nutritional and health consequences are also widespread, and appear to connect to anxieties about knowledge and control (or lack thereof) over changing diets.

From these findings we see little evidence that adults are unconcerned or ignorant about the kinds of foods and diets that would give them good health and nutrition. Instead, most people believe that (if they are able to afford them) what they think of as their customary diets would ensure good health and physical development because they would provide safe, diverse foods prepared using skills and recipes that are handed down through community food cultures over generations. The anxieties are partly about the loss of this knowledge and these food cultures. They are justified in that the knowledge of how different diets affect people builds up gradually over time; the accumulated knowledge of generations. 
By contrast, changes in the food available to us are rapid, substantial and generally unregulated by concerns about public health, beyond a very limited and often thinly regulated focus on food hygiene and safety.

We look first at how people in different places experience these changes. We then turn to how those changes are experienced differently according to how people relate to food production (including preparation and serving) and consumption. This leads to a discussion of the class, gender and generational differences in changing food habits that draw attention to broader issues about how food is produced, distributed, marketed, prepared and served. People's worries and pleasures are then related to the institutional, social and individual mechanisms in place to protect against or resist unsafe or unhealthy foods. 


\section{CHANGING FOOD CULTURES}

\subsection{Traditions in decline}

In all countries and most sites in this study, people are talking about 'traditional' foods they no longer eat or eat only occasionally, or which are declining in popularity or being prepared differently. Availability, cost and time are key factors driving this change, both in terms of what is dropping out of diets and being introduced. But it seems clear that younger people across the board have more pronounced tastes for calorie-dense and commercially processed foods as regular features of their diet than older generations. The overall picture is one of timeconsuming 'niche' customary foodstuffs and recipes being phased out with the pressures of time, money and the appeal of novelty. While the availability of food is more assured as long as you can afford to pay for it, from what people say, there is less of the older seasonality in local produce and more homogeneity between and within societies. In most of these settings the consumer can choose from a fast-growing range of new processed foods from elsewhere.

\section{Picture 1: The Karibuni Hilton restaurant in Lango Baya, Coastal Province, Kenya.}

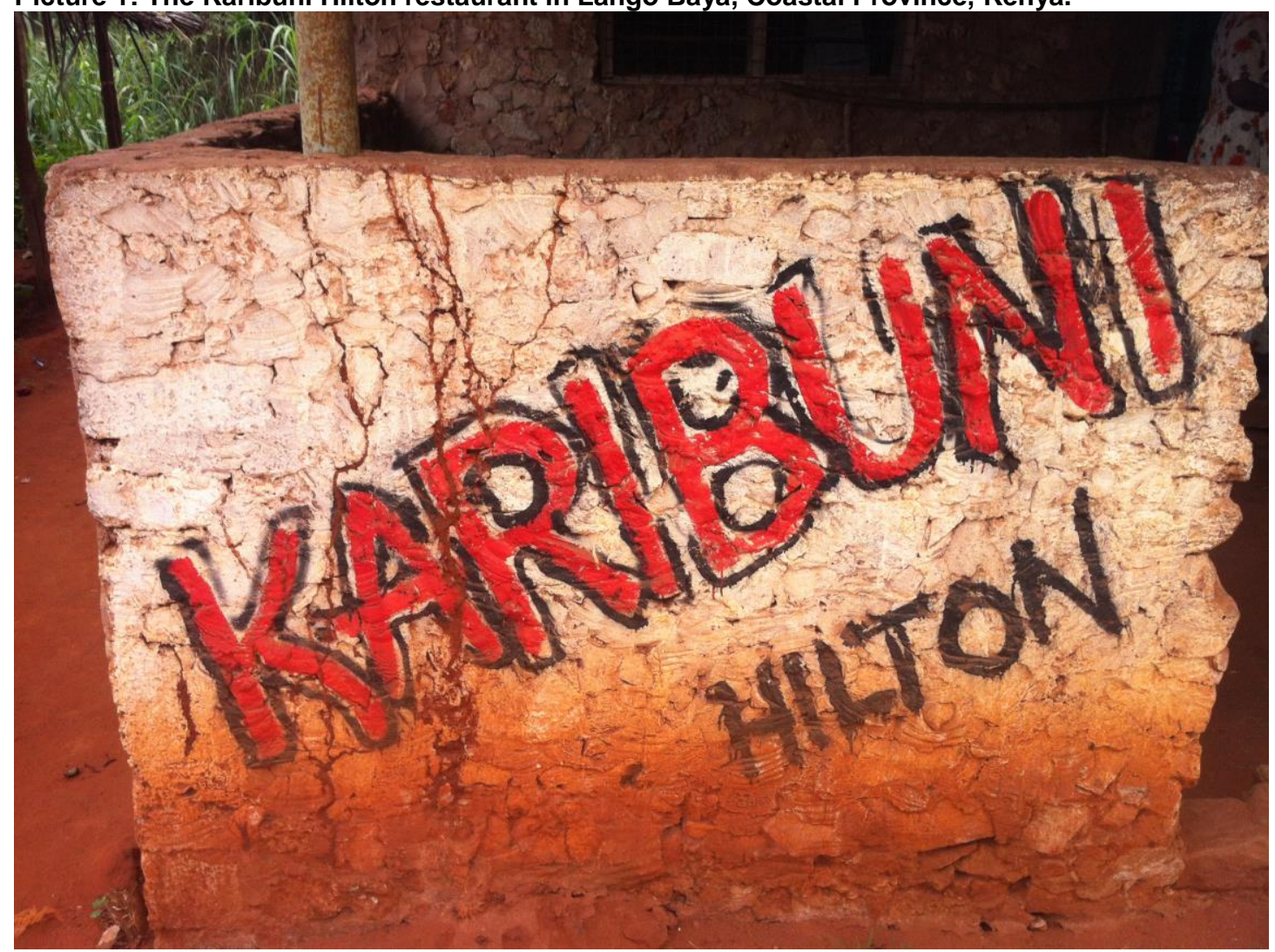

Credit: Naomi Hossain 2012

People reported on several trends as they saw them. One direction of change in staple consumption appears to be a move from relative diversity in grains (sorghum, millet, teff, quinoa) to reliance on the major monoculture crops of maize, rice or wheat (mentioned with particular concern by research participants in Burkina Faso, Ethiopia and Bolivia). Regional diversities in staple foods were also said to be declining. In cities with more developed food markets and consumer tastes, a second stage of change is a growing preference for more processed staples. Quite remarkably, for two countries in which rice accounts for between 
half and 60 per cent of all calories, we heard in Bangladeshi and Indonesian communities that children were eating less rice. In Indonesia the instant noodle, fried, boiled or in soup, is the ubiquitous focus of this changing diet. In Bangladesh, a mixture of snack foods and other items is preferred. In Bolivia, parents explained that children now prefer bread to phiry (a dish made with toasted flour), with one mother explaining that this might be because it takes a lot of work to prepare and hungry children demand to be fed more or less instantly. In Burkina Faso, people are said to eat less bikalgo than before, a fermented condiment. It takes a long time to prepare and has a strong distinctive taste. Older people in Burkina Faso also used to eat dishes prepared with water lilies, which they said were good for knee problems; this is less the case now. In Guatemala, people still prefer to eat hilachas, revolcado (traditional tomato/tomatillo-based beef stew dishes) and beef and calves' broth - but cannot always afford to. These can be expensive and are not always widely available. Instead, people often buy tacos, gringas, burgers and other items that are affordable and common.

In Ethiopia, people noted several recent changes in what they and the people around them were eating. Young people in Kolfe sub-city in Addis Ababa said they were eating less enjera (fermented bread made from teff flour), replacing it with dabo, or wheat flour bread, as their staple. By contrast, others from the southwest of the country are eating fewer traditional foods such as chuko, barley preserved with butter and torosho, leavened corn bread. They say they now eat more enjera, seen as traditionally the food of the Amhara people and Addis Ababa. ${ }^{3}$ From women in farming households in rural Western Oromia in Ethiopia, we heard that chechebsa (a flatbread fried in clarified butter and the spice mix berbere), porridge and yoghurt used to be common and respected foods in the community, served to guests and eaten at home. One woman explained that these foods were being replaced with shiro wat (a pea stew, increasingly made with pre-packaged ingredients), biscuits and packaged juices. Dairy, particularly butter, was being replaced in traditional dishes with processed vegetable oils, some of which are of dubious quality.

Mr A., a father of ten and an irrigated maize farmer in Oromia, Ethiopia, told of the changes he had seen in his 62 years:

Eating porridge with butter was a common food in the past. And drinking milk was very common.... Over time, people began to grow crops and the expansion of farming both through rain and irrigation contributed to the decline in grazing lands. ... Porridge in particular has become a precious food and it is replaced with bread or enjera with cabbage and other sauces. Now eating outside has become a culture and this has been expanding. The trend shows that eating outside will continue to dominate the feeding culture of the people. I do not think that the traditional and cultural foods such as porridge and butter and milk, chechebsa and chuko will ever come back.

Mr A. noted that in the past year, local eateries had started up to cater to the demand for eating out, and farm labourers and other young men made good use of these places. Like Mr A., other older people were also able to connect their changing food habits with the often rapid changes they are experiencing in their local economy, and in how their society is adapting to meet them. In Bolivia, 79-year-old retired miner, Don M., described how his family's diet had changed with what was available in the local market and their work patterns, so that earlier variations were being replaced with more purchased products, like everyone else:

[M]y wife was from somewhere else, she was from Araní, and she was more used to eating grains, she couldn't be without mote (boiled maize) in the house, and it was very rare that there was none in our house... Even now, if there's no maize here for mote we have to go out and buy some, but it's no longer a custom. I'm used to having mote, and so are my children. (...) Before, we used to eat more grains, quinoa for example, 
we were never without that either, but since about two years ago it's disappeared and it's very expensive now. We only make quinoa about once a month now. Api (maizebased drink), too, we only make it from time to time now, now it's all tea, coffee or chocolate. People don't have a cooked meal for breakfast now. It's also because the type of work is different, I still work as a driver sometimes and that kind of work is easier, it doesn't require much strength. That's why I say that kind of breakfast is enough, but if you're working in the mines or on a farm it's different, you have to eat four times a day otherwise you can't work properly.

\subsection{The novelty and pleasure of foreign foods}

Despite nostalgia about 'the way we used to eat,' cuisines are not fixed in time or place. Some food tastes are so localised that they are unlikely to travel well (Bengal's pungent dried fish relish shutki, West Africa's astringent bikalgo or southeast Asia's beloved smelly durian fruit, for instance). But it is also true that some of what we hold most dear as our traditional foods are in fact foreign imports from earlier moments of integration in the world food market. As the earliest of the countries to industrialise and globalise through trade and empire, it is not surprising that many 'British' foods have their origins elsewhere: the deep-fried potatoes of fish-and-chips fame, Lea and Perrins' Worcestershire Sauce and Chicken Tikka Masala are just a few of the British specialities with imperial ancestry. ${ }^{4}$ That most Italian of foods, pasta, owes its origins to the Marco Polo Chinese expedition in the thirteenth century or to North African traders reaching Sicily a century earlier (Alexander 2000). Malawians call their favourite variety 'the maize of the ancestors' when it actually originates in the Americas (McCann 2001). As the food historian Rachel Laudan points out, well into the recent past:

Local foods were the lot of the poor who could neither escape the tyranny of local climate and biology nor the monotonous, often precarious, diet it afforded. Meanwhile, the rich, in search of a more varied diet, bought, stole, wheedled, robbed, taxed and ran off with appealing plants and animals, foodstuffs and culinary techniques from wherever they could find them (Laudan 2001: 38).

Yet people also tend to be cautious adopters of new foods, mainly because biological instincts are powerful sources of disgust and fear. ${ }^{5}$ Given local preferences and a biologicallyfounded suspicion of foreign fare, it is interesting to note that how people in the communities we visited absorb new influences and products without great difficulty. As we will see below, this has a lot to do with the sense that new foods and new ways of eating offer good value whether it is novelty and variety, easy access, household economy or pleasing the children that is what is valued. Of course, it makes sense that people always seek better value in the foods they produce or procure, even if what is valued changes over time and place.

Some of the diets of the people in our research proved to have an unexpectedly eclectic and/or global range of influences and cultural references, particularly in cities. In terms of the varieties of staples and processed foods, the influence of the post-war wave of global food system integration is plain. But earlier waves of internationalisation were also apparent, for instance in the availability of varieties of roti or chapati (wheat flour flatbreads, sometimes fried) in Bangladesh, Kenya and Pakistan, while the samosa (pastry with savoury fillings, probably originating in Central Asia) was a favourite snack in all three countries, as well as in Ethiopia and Zambia. Aji-no-moto $®$ (a Japanese 'umami seasoning' made of monosodium glutamate or tasting salt) was mentioned by brand name in places as far apart as Cochabamba, Bolivia and Dhaka, Bangladesh. In Indonesia, one family was such a fan of the condiment that their dishes featured its slogan. ${ }^{6}$ Ingredients in customary meals might be 
cooked from imported onions or newly-grown cabbages, or oils pressed or fish sauces produced far from home. Everyday eating is already a fairly cosmopolitan matter.

\section{Picture 2: A bowl of mie bakso or beef meatball and noodle soup, Indonesia}

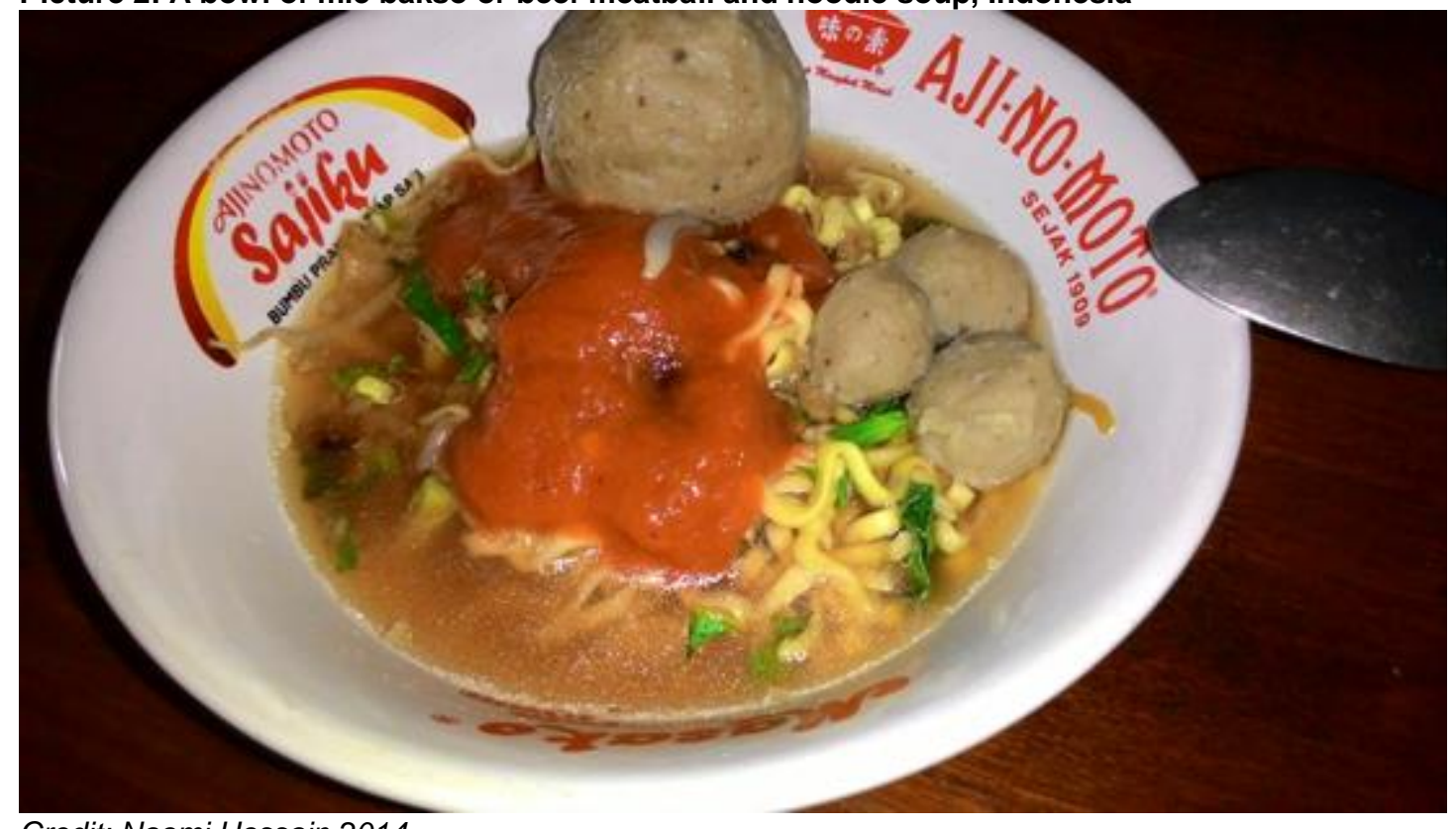

Credit: Naomi Hossain 2014

We know that strong drivers of change in food cultures in other societies have been economic development and global market integration, and the changes in social organisation that these entail (for a sample see Goody 1997; Mwangi et al. 2001; Raschke and Cheema 2008; McCann 2001). Imperial and colonial rule have also played a major part in deliberately changing food systems (see, for instance, Fraser and Rimas 2010), as have episodes of major conflict (Collingham 2012). Importantly, from the point of view of the objectives of the research agenda of the Life in a Time of Food Price Volatility project, the wake of previous major food crises have also seen shifts in food cultures. Wheat is thought to have been introduced into the staunchly rice-eating regions of Bengal as famine relief (Robson 1976). Wheat consumption was then steadily instilled as a habit among the (poor) population of East Pakistan/Bangladesh through growing dependence on food aid between the 1950s and 1970s (Ahmed, Haggblade and Chowdhury 2000; Atwood et al. 2000). Some attempts to change food cultures and create new markets have been deliberately introduced after food crises, such as that with genetically-modified grains to drought-stricken parts of southern Africa during the 2002 food crisis (Zerbe 2004) also (Clapp 2012).

The ways food habits seem to be changing offer many advantages: novel tastes and pleasures, speed and convenience, affordability, and the chance to be part of modernity and international culture. But many people are ambivalent about how their society's food habits are changing. Mr C., the 45-year-old ward councillor in Kabwata in Lusaka city in Zambia, is optimistic about food trends in his ward:

People are now moving away from these takeaway [fast food] places and are going back to traditional food. We have these mini matebetos [traditional food restaurants] everywhere in Kabwata and they are filled with more people than the other places. People are appreciating these types of foods because they are very safe as most of the foods are organic ... 
Not everyone views the reliance on traditional foods in Kabwata as a matter of health consciousness, however. Other residents of this poor neighbourhood of Lusaka say their food habits have not changed and apart from simple items like popcorn or other snacks, they rarely buy cooked food outside, nor do they appear to buy much in the way of additives or sauces. For most families on low incomes this is not because they do not want to but because they cannot afford to, and have never acquired the habit. In a focus group discussion of young people, one took the view that fast food was the food of the rich, so that people had become fat from eating burgers, pizzas and the like: 'You can tell now who has money by the weight of that person.' One of this group of twenty-somethings, employed in the informal sector when at all, commented with a touch of schadenfreude that 'foods like chips and pizza are causing funny diseases like diabetes and high blood pressure. We say these are rich people's diseases as poor people don't get such diseases because they can't afford such type of food.' Similar views on the health-giving qualities and positive impacts on life expectancy of traditional foods were heard across the sites.

Ambivalence about changing food cultures reflects, among other things, the growing distance between people and their food (Clapp 2011). This is expressed as fear and disgust about new foods, whether because they do not know how it is grown, stored, prepared or served, or in others because (they believe) they do. The research uncovered a long list of items that people fear or try to avoid because they think they may be contaminated with pesticide during the growing process; stored badly so that they rot, preserved with dangerous chemicals or left to the elements or vermin; cooked, prepared or served in unhygienic ways or contain additives and adulterants to make them look and taste good. 


\section{WHO EATS WHAT, WHERE, WHEN, WITH WHOM AND WHY?}

By no means does everyone consider all the recent changes in food cultures to be bad. For a variety of reasons it makes sense or gives pleasure to different groups of people to change their eating habits and they do so in different ways. It should be noted, first, that for some people and communities, changing food habits are passing them by, largely because they have not reached their areas of the world or because they cannot afford new foods or to eat out. This is particularly noticeable in Zambia, but in Vietnam and in Indonesia, too, people did not notice that their food habits had changed notably in recent times. In the Zambian communities research participants continued to cook and eat mainly at home, whereas in the six Southeast Asian sites, processed foods, street foods and meals in restaurants or stalls have been established behaviours for some years. And within the 23 sites a world of diversity can be seen in who eats what and how, and how long they have been doing so, as well as in how they understand those processes of change.

Availability of street food has changed so profoundly in many places as to affect all kinds of people, however. In Dhaka, in 2003 large parts of the Notun Bazaar slum were evicted and shops and kiosks took over the abandoned sites. Female respondents in a focus group discussion explained that before the evictions residents had to walk far to get ready-made foods, but now there are shops outside every house. This they saw as one of the main reasons why people consume these foods. In Hanoi, one respondent explained that since the opening of a supermarket closer than the local market, he buys canned meat. Similarly in Cianjur in Indonesia some respondents linked the increase in the consumption of ready-made foods to the opening of Indo Mart in the district.

Despite the great variety of contexts and reasons for taking up new food habits, a noticeable pattern of class, gendered and generational change emerges from across the 23 sites. Eating out provides a substitute for home-cooked meals and trade is booming. Home cooking is also changing: in many countries people are cooking with additives such as monosodium glutamate to make food taste better and pre-processed foods such as noodles and pasta that cook quickly. Street foods and fast foods' main appeal is not only about price. We find that very often despite a wide belief that street foods are 'cheap', a lot of the time the value is a combination of positive factors such as time-saving, convenience and desire. But these advantages are not unalloyed; they are accompanied in every country by anxiety about threats to health and family.

\subsection{Class and the cost of food}

Unsurprisingly, how much disposable income respondents have is a key factor in whether or not people are able or would chose to consume outside foods and which kinds of foods they have access to. In Kami an urban neighbourhood of Cochabamba, Bolivia, a schoolteacher argued, 'it's people with less money who are eating these foods, or at least the sausages, because in some cases, incredible though it may seem, they're cheaper than meat on the bone'. In a focus group discussion with retired miners in Guatemala, one man argued: 
Buying food in the street is no longer a matter of class. The difference is that people with more money eat in the sit-down restaurants and those who don't have much money eat at those places where you crouch down on the ground. (...) both rich and poor eat in the street. The difference is that the food safety office goes and checks up on the good restaurants. Here, in contrast, the food safety officer is just for decoration, you never see her working.

Price affects what people choose to cook too. In Burkina Faso, for instance, it has become unthinkable to cook a meal without 'Maggi', a famous stock cube/flavouring in West Africa. In Kaya, a district town, a 51-year-old woman taking part in in a focus group with other female civil servants, explained that she first saw a Maggi Cube when aged seven her mother returned from a trip to France. At that time, it was an ingredient mostly used by well-to-do families. Now, participants in the discussion explained, gone are the days when they could buy enough meat for a sauce with 100CFA (approximately £0.11), and Maggi has become the staple flavouring to make a meal 'acceptable'. In both the rural and the urban research sites in Burkina, respondents would often say that if one does not put Maggi in the sauce, no one will eat the meal.

For people on precarious incomes in the informal sector, food choices are very much influenced by price. Mrs B., aged 41, a landlady and community leader in Dhaka explained that:

People eat almost whatever they get in cheap price. Some people bring the food left in the community centres after an occasion to the slum and sell those in cheap price among the slum dwellers. These items get sold like hotcakes as they are cheap and tasty. Plus, the people here cannot afford these items fresh as items like biriyani are quite pricy for them.

In Kaya, Burkina Faso one householder said, 'I think that people eat these foods because of poverty; they do not care anymore about food good quality, they just need to feed themselves.' Many of the workers living under the harshest conditions choose high calorie street food because it is cheaper. In the Kabwata borough of Lusaka city in Zambia, men eat fritters as they are cheaper than bread and also more filling. Similarly in Mukuru, an informal settlement in Nairobi, Kenya it is cheaper for people on their way to work to buy mandazi, deep-fried doughnuts, than bread. On the other hand in Kami in Bolivia, it is cheaper to buy bread than the traditional staple quinoa.

The price of a dish or a meal includes more than the cooking ingredients that go into it. When thinking about the cost of food, people often factor in the price of gas, kerosene or firewood. Mr A., 42-year-old waste recycling worker in Dhaka explained:

We cannot cook quickly because we don't have a gas connection. On the other hand, kerosene is costly. If you have money then you have everything, if you have no money then you have nothing.

Likewise in Chichicastenango, Guatemala a member of a youth group explained about the cost of cooking:

In our house, when we try to cook chips, it generates costs of gas or firewood, to buy the potatoes, cooking oil plus the preparation time. Instead, with the street food vendors it is already prepared and ready-to-eat. 
In Vietnam, where it is more common to see the whole family eating out than in many other countries, poorer people are increasingly finding that they can do better at home. Mr D., 38year-old farmer in the village of An Giang said:

Of course, prices of processed foods are higher. For example, prices of a bowl of noodles are about VND25,000-30,000, so we less likely eat vermicelli than before. Now, I also buy ingredients for cooking vermicelli for breakfast, so we do not have to dine out anymore.

Buying processed food is often a sign of wealth. In urban Guatemala, having a 'mega' ( 3 litre bottle of soda) on your table while you eat means that you are eating well. One respondent explained: 'they are managed as a matter of "status", because even in the [TV] commercials, people are eating and celebrating...'

Different foodstuffs are associated with status in each site. Thus, chicken is 'prestigious' and being fat is admired and considered a sign of wealth in Kabwata in Zambia. In Karachi, one respondent said 'people like to eat at restaurants so they can brag about it later'. In Kami, Mrs C. said that eating traditional foods such as boiled or toasted maize is looked down upon, because it is 'country food.' A young man explained:

People are letting themselves be manipulated by the market. Children and young people no longer want to eat lawa (traditional thick soup) or toasted grains, they feel embarrassed to eat our traditional foods; they prefer popcorn and chips to toasted and boiled grains.

In the same group another young person added, 'If a child takes boiled or toasted grains to school people might say he's eating Indian food or that he's an Indian.'

While status and class clearly make a difference to how a food culture changes in a given place, we find that other vital determinants, in particular, gender and generation are also key to decisions about what and how, where, and with whom to eat.

\subsection{Gender and generation}

\section{Men: eating out}

Men eat out more these days in almost all the study sites, reflecting changing livelihoods, rising demand and increased supply. The vital fact is that cooked food is available fast and close to their places of work. When people talk about the rise in eating out, they are mainly talking about men eating the main meal of the day away from home. Men related stories of eating out alone or with other male friends. An apparently growing number of male agricultural wage workers or non-farm labourers and market traders in rural areas, urban transport workers, security guards, factory workers, traders and farmers selling produce, construction workers and others find themselves a) away from home throughout the day; b) typically doing strenuous physical work or travelling that builds up an appetite; c) with cash in their pockets; and d) met with a growing range and number of restaurants and eateries. In Nessemtenga, in rural Burkina Faso, it is men (sometimes accompanied by children) who are the ones eating in the market, while women eat at home. In most of the urban sites, notably Karachi, Kami, Addis Ababa and Nairobi, it is bachelors or men whose partners live in another place, who are the main consumers of street foods. In Mukuru, Nairobi, Mr N., a 21year-old man working as a clerk and delivering parcels explained that, 'for a bachelor like me I hardly cook unless my girlfriend comes to visit and she cooks. I usually go out to buy ugali and take it with eggs or beans'. This was echoed by another Mukuru resident, Mr P., a 35- 
year-old NGO worker who said 'it has been a change that I eat what I find in restaurants and at any time. Since my wife went to work in another region I have changed my food habits.'

Picture 3: Ireen's 'fast food' restaurant in Chikwanda, Northern Province, Zambia

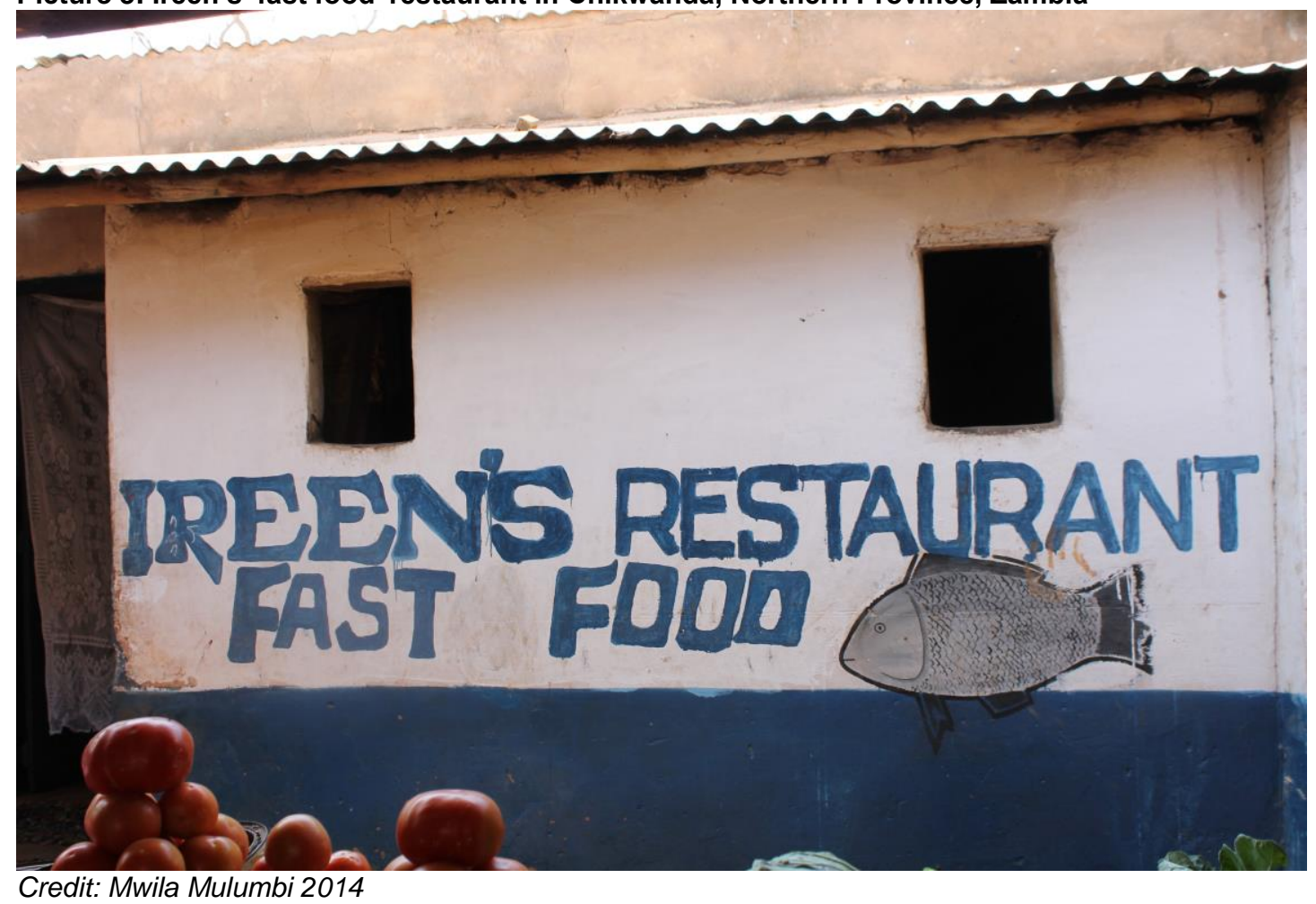

What are these adult and young men eating outside the house? In some cases, they are enjoying dishes they do not get at home and in others they are buying what is easy, affordable and full of energy. Rickshaw-pullers in Bangladesh perform physically arduous work, and are often in need of a quick calorie fix; they pick up ultra-cheap deep-fried snacks like shingaras or samosas (fried pastries with vegetable or meat fillings) or puris (puffed breads, sometimes with lentils or potato). Eating out on a regular basis is a new thing for rural Bangladeshi men. According to a group of agricultural labourers ranging from their forties to their seventies in Koira, Khulna in the south of Bangladesh, there is much more eating out now than five years ago. This is because after cyclone Aila struck in 2009 people found they had cash in their hands for the first time, because NGOs came to help and there was plenty of fishing and fish sales. Men are eating out more because the cyclone left much of the paddy lands waterlogged and salinated, so that they could not return to rice farming. Some shifted to fishing and others took up risky activities in the Sundarbans forest or migrated, while others started shrimp cultivation. They began to try outside foods. Fish sellers started to buy sweets from the market at the end of the day. Infrastructure has improved too, so it is easier to get to the shops. Even the food consumed at home, such as the staple rice, is more likely to be bought than before the cyclone, because fewer people can grow their own.

In many of the rural sites new outlets have sprung up to serve hungry working men. Farmers who go to market in Nessemtenga might eat rice once they get there, after having eaten the traditional staple tô, pounded millet or sorghum in a vegetable sauce, for their morning meal at home. Men in Burkina Faso say they like to eat roasted and grilled meats when they go to town. In the rural Ethiopian community in western Oromia, agricultural production processes have changed in recent years; farmers with larger acreages have introduced modern technologies and rural wages for landless labourers have risen. A growing number of agricultural workers have moved in and, to feed these men, new restaurants have appeared in the village over the past year, selling different kinds of food including (according to young 
men who frequent them) a variety of fish preparations, as well as alcohol-free beer and farso alcoholic local beer, pasta, avocado, biscuits and breads. Demand is high and the restaurants are already serving the same kinds of food that once could only be found in towns.

Many young men in urban areas have no kitchen facilities, and the cost and effort of cooking single meals far outweighs the ease of buying a simple dish of the local staple. In Mukuru, for example, githeri, a mix of maize kernels and kidney beans often with a generous sprinkling of commercial flavour enhancer, has long been popular, but of late, sales have shot up. One githeri vendor was said to have increased her sales fivefold in the past year. It seems that there are more people with some cash in their pockets but without the ability to prepare palatable meals.

\section{Picture 4: Preparing githeri in Mukuru, Nairobi}

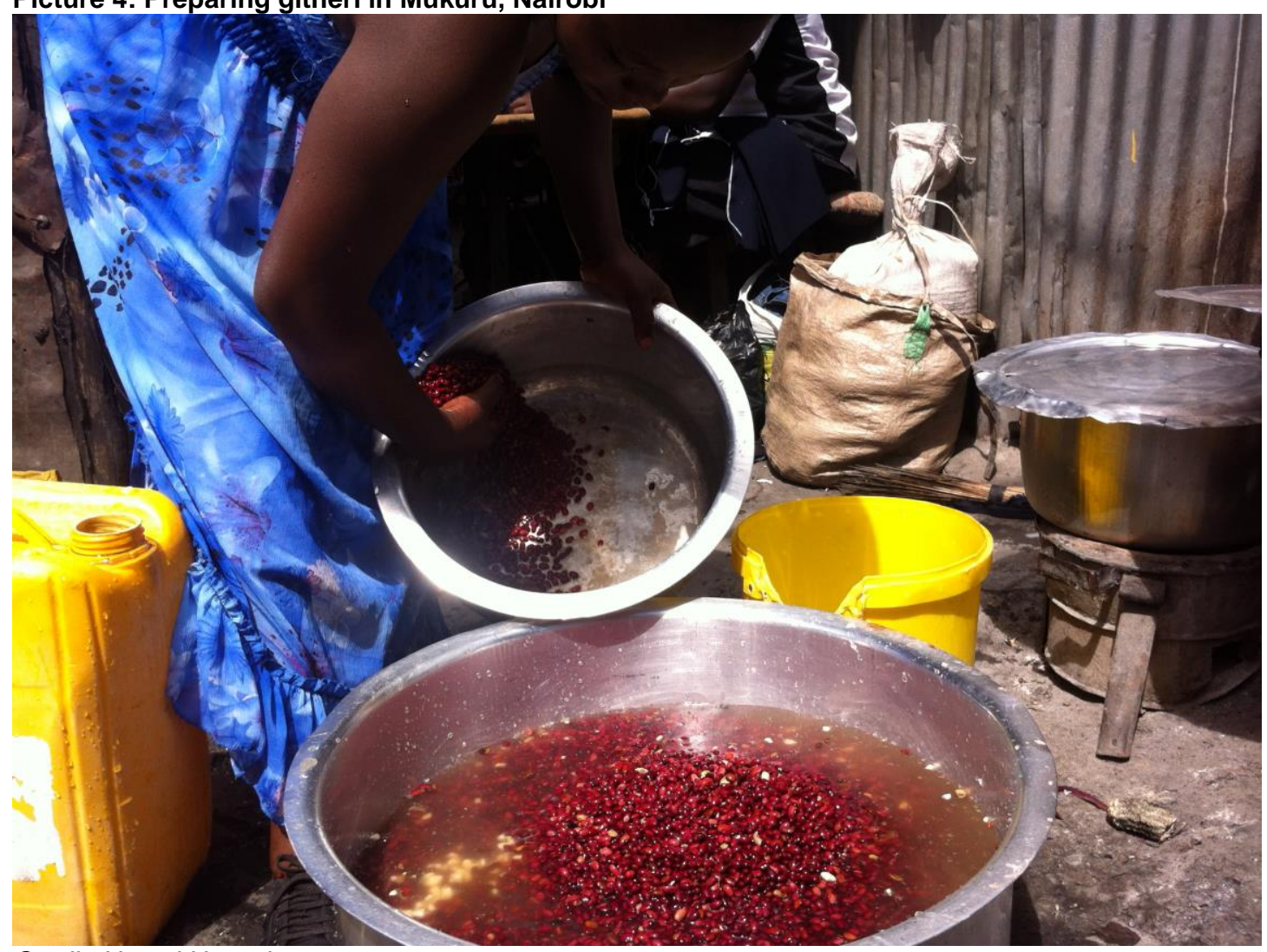

Credit: Naomi Hossain, 2013

It is not all about price or convenience. Sometimes, we learned, when men say it is cheaper to eat out, what they mean is that the foods that they enjoy eating outside would be too expensive to cook at home for everyone, even though there are cheaper home-cooked alternatives. A man in Kabwata in Lusaka explained:

The rich people are the ones who eat fast food not us. Why should I buy pizza costing K60, when I can buy a bag of mealie from that? It makes no sense for most of us.

For others, though, there is a question of social status. Being seen to eat chicken, however poor its quality, is to be seen to be someone in Kami, Bolivia. Male householders there also explained how they would not be seen eating traditional food. In Khulna, many male respondents talked about eating out as a means to spend time with friends and 'gossip'. This was echoed in both sites in Burkina Faso, with Mr Z. saying that 'having coffee and bread outside is an opportunity to talk with friends (...) While eating these foods we spend time with retired friends, share food with them'. In another focus group discussion in Nessemtenga, 
older men explained that eating out is also a way of not eating alone, now that family life has changed and is no longer the place where everyone gathers to eat together.

\section{Women: buying in}

While there are probably no societies in which adult women are not expected to bear primary responsibility for feeding the family, there are increasing pressures on women's time. More men eat out, we hear, in part because women have less time to cook for them at home than in the past. Also processed and purchased foods are becoming more common in many kitchens. Most notable among the changes in women's consumption patterns is a growing tendency to buy ready-made sauces or additives such as sauces and stock cubes. These are not staple foods, but they replace a number of other items such as onions, garlic, ginger, chillies and spices and fill up the space with flavour left by diminishing amounts of meat and other expensive items. This shift is particularly strong in Indonesia and is also increasingly the case in Burkina Faso and Kenya. In Guatemala, we heard a great deal about 'consommés', another variety of stock or sauce substitute. Other quick fixes include buying packaged 'fruit juices', partly-prepared meals, particularly poultry and meat, and quick-cook or instant noodles (so common in Southeast Asia as to go entirely unremarked upon). Getting foods from outside can often be a means for a busy woman to receive guests, as illustrated in this quote by Mrs A. in Dhaka:

When a guest comes to your house, you cannot let him/her go without entertaining $\mathrm{him} / \mathrm{her}$ with some food first. But it is not always possible to cook because sometimes there are no ingredients to cook with. In such cases, buying foods from these shops can save your face.

Cost is crucial to women on low incomes and home preparation is often the cheapest way to feed the family. Women consume less and eat out less than men, either on the street or in restaurants. In Khulna, Bangladesh, Mrs N., a 42-year-old housewife said that 'we women do not eat foods from outside, but the men and the children do eat biscuits, cakes, sweets and drink teas outside of home.' In Dadu in rural Sindh in Pakistan, we found that while men go to the town of Makhdoom to eat from restaurants, women do not go out to eat. At most, women eat pakoras (fritters) that are sold in the neighbourhood. Housewife Mrs M., aged 28 said, for example:

Women do not eat more outside food, they just prefer any type of fry or nuts. Women are mostly eating these foods at the evening. They can get a little leisure at evening after have passed the workday. They chat with the neighbours at that time and eat these foods.

Women demonstrate, by and large, a more comprehensive understanding of what goes into meal preparation and thus how to save money when cooking for a family. This highlights the fact that cooking, a form of unpaid care, not only requires time and effort, but also knowledge and strategy, as Mr M., a 26-year-old adviser at the Midwives' Council in Guatemala, explained:

I tell [my sisters] to go out to buy some food and they say: 'no, because I am going to prepare this'. They think fast when it is about saving money. They see how they can save one quetzal at a time. The men think: 'it is just one quetzal'. But one quetzal after another is how the weekly budget is spent. 
Picture 5: Cooking Tô for an extended family, Kaya, Burkina Faso

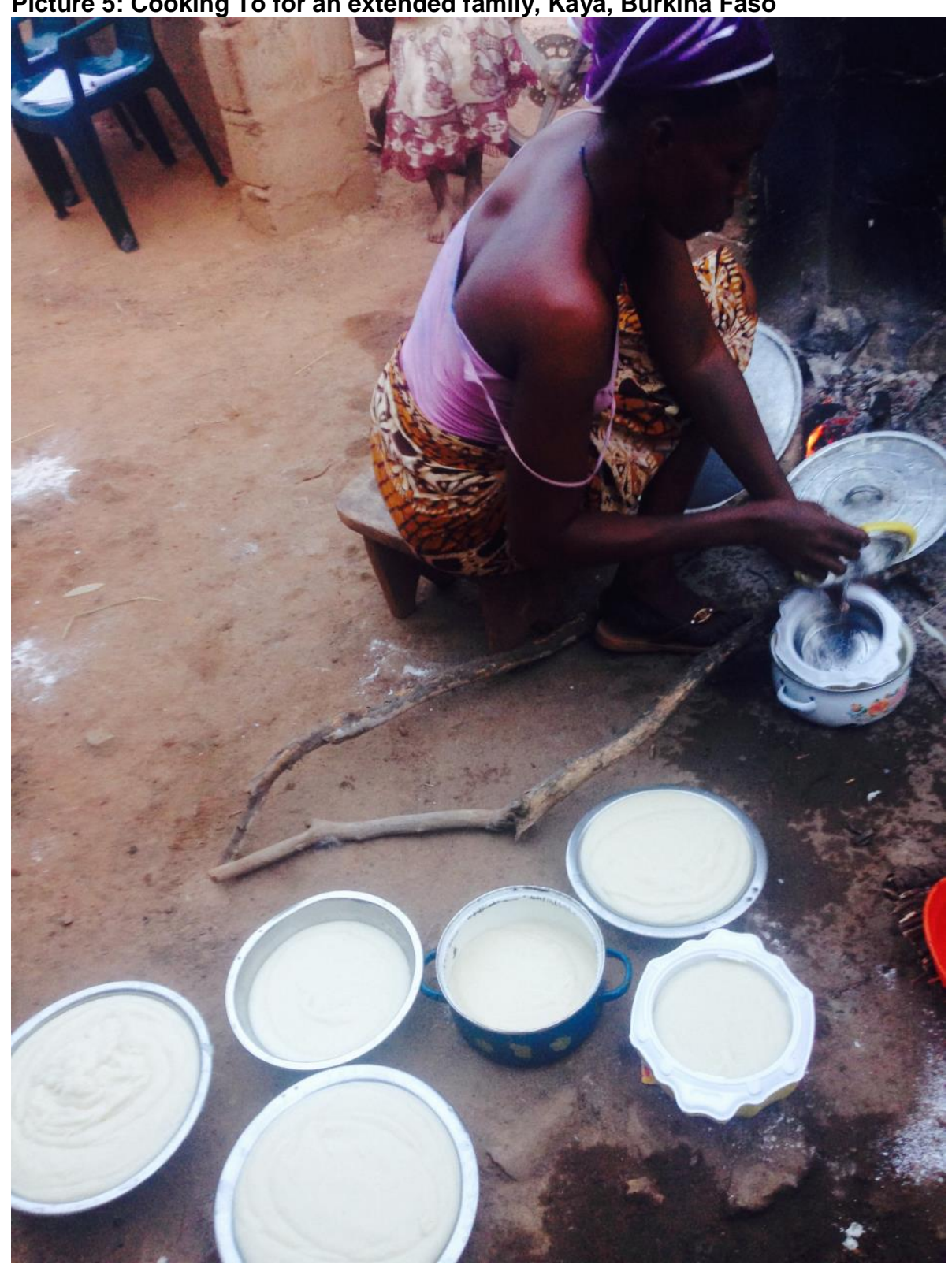

Credit: Alexandra Wanjiku Kelbert 2014

\section{Children: snacking}

It is with young people that we see the most profound change across all the sites. Children and young folk are eating more snacks and replacing their usual meals with junk or fast foods. These are often highly processed and packaged products with high concentrations of fat, sugars and additives that are marketed specifically to the young. While often mass produced items from large domestic or multinational corporations, in many places local producers also appear to do a good trade in local delicacies, not all of which could be accused of being grotesquely unhealthy, but they represent a loss of control for parents. A father in Bangladesh complained: 'My youngest son never stops crying until he gets chips and my elder daughter and son refuse to go to school without taking money. I don't see what they eat outside.' In Pakistan, wily mothers are short-circuiting their children's clamours for street foods by roasting and seasoning their own snacks at home, saving money and protecting their children against unsafe foods. In Indonesia, mothers try to offer children snacks of home-cooked tofu, rice cakes or fruit kebabs. 


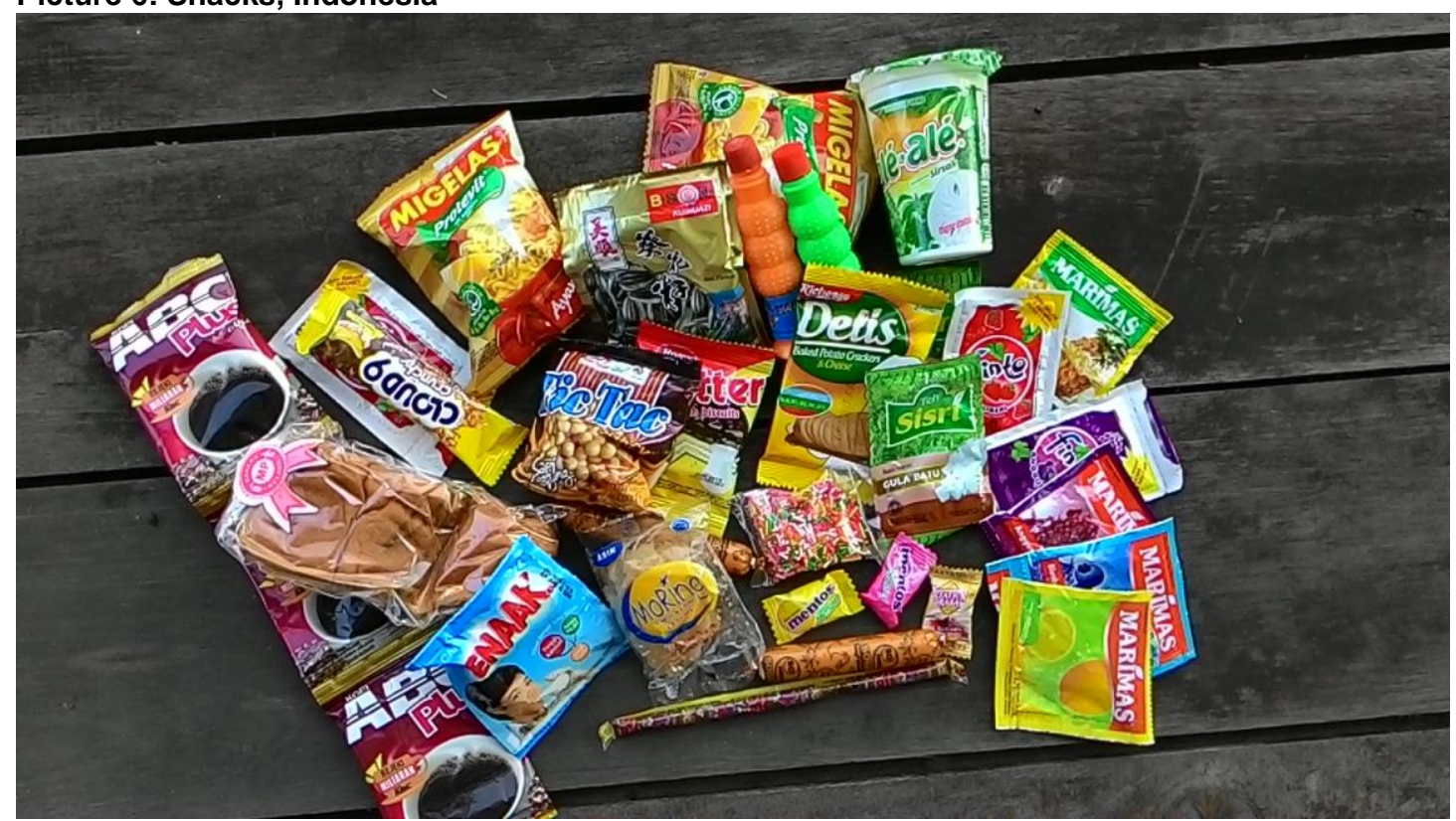

Credit: Rachma Nurbani 2014

Children's snacking has a great many dimensions. Parents feel a lack of control. They worry that they do not know what children are eating, they are concerned about food safety and the longer-term nutrition implications of the food that they know or suspect their children to be eating. Children often eat deep-fried or sugary foods with no discernible nutritional value other than calories, which, like the fritters fingered by a Kabwata school teacher, may actually be harmful if cooked in bad oil or with old ingredients.

\section{Picture 7: Fritters popular in Kabwata schools in Lusaka, Zambia}

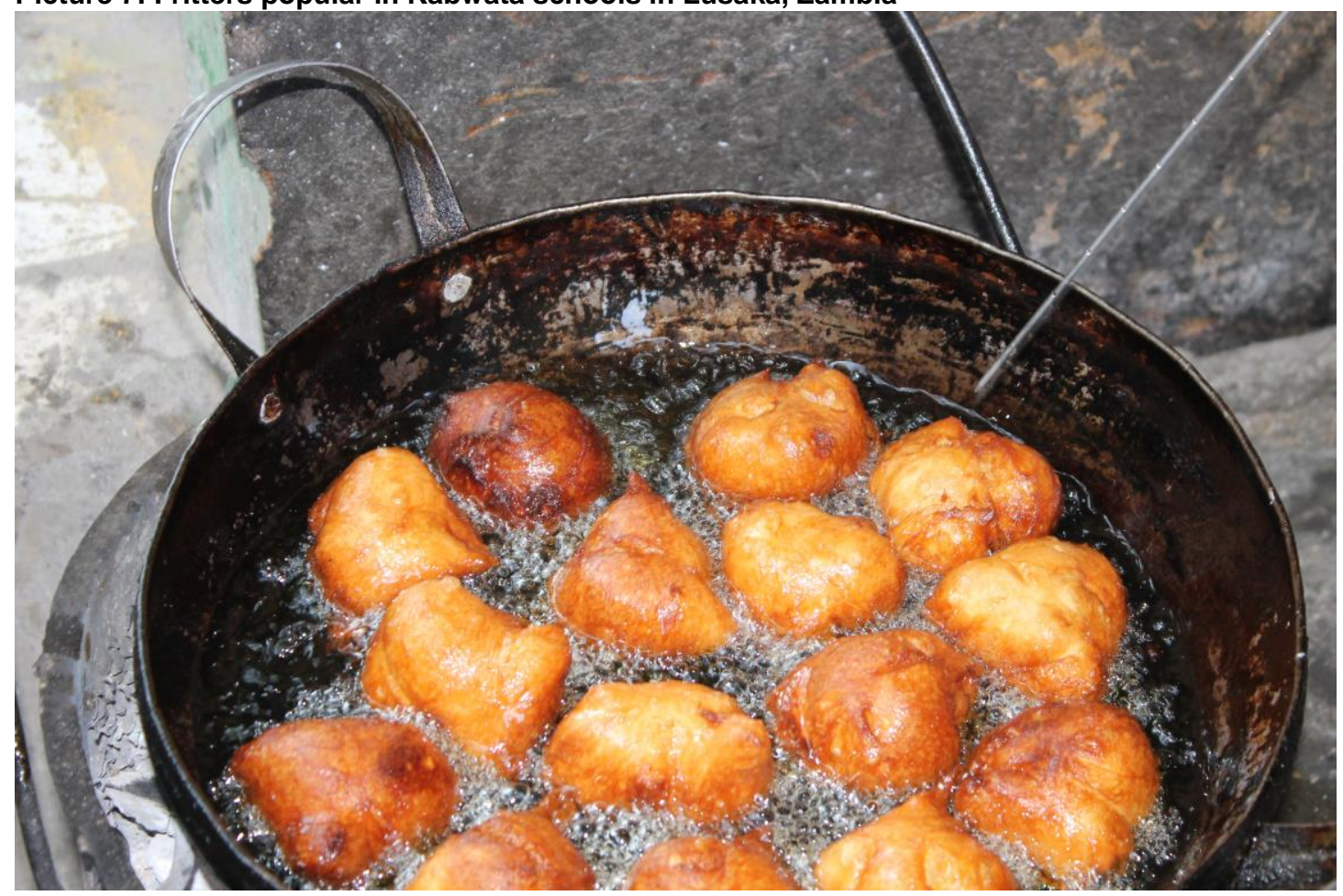

Credit: Mwila Mulumbi 2014 
In several places, we were told how children tend to eat at odd times and the habit of eating together is being lost. In Ethiopia, Guatemala and Burkina Faso, adult men thought that this meant fewer opportunities for teaching children social norms and discipline. In a focus group of rural Burkinabe men in their sixties, one explained that:

In the past people used to say that someone who eats outside cannot take good care of his family. At that period parents could punish children when they were mistaken, but today they cannot do it anymore. If they do so they will go out of the house and eat these outside foods.

Unsurprisingly, snacking at school is a major feature of children's food habits. During breaks and after school, vendors appear to have a captive market. In Indonesia and Bangladesh, parents complain of having to provide pocket money so their children can keep up with their friends and buy snacks for the playground. In some cases, these amounts appeared to be non-negligible proportions of a family's daily spending.

Picture 8: Food vendors in school compound in Indonesia

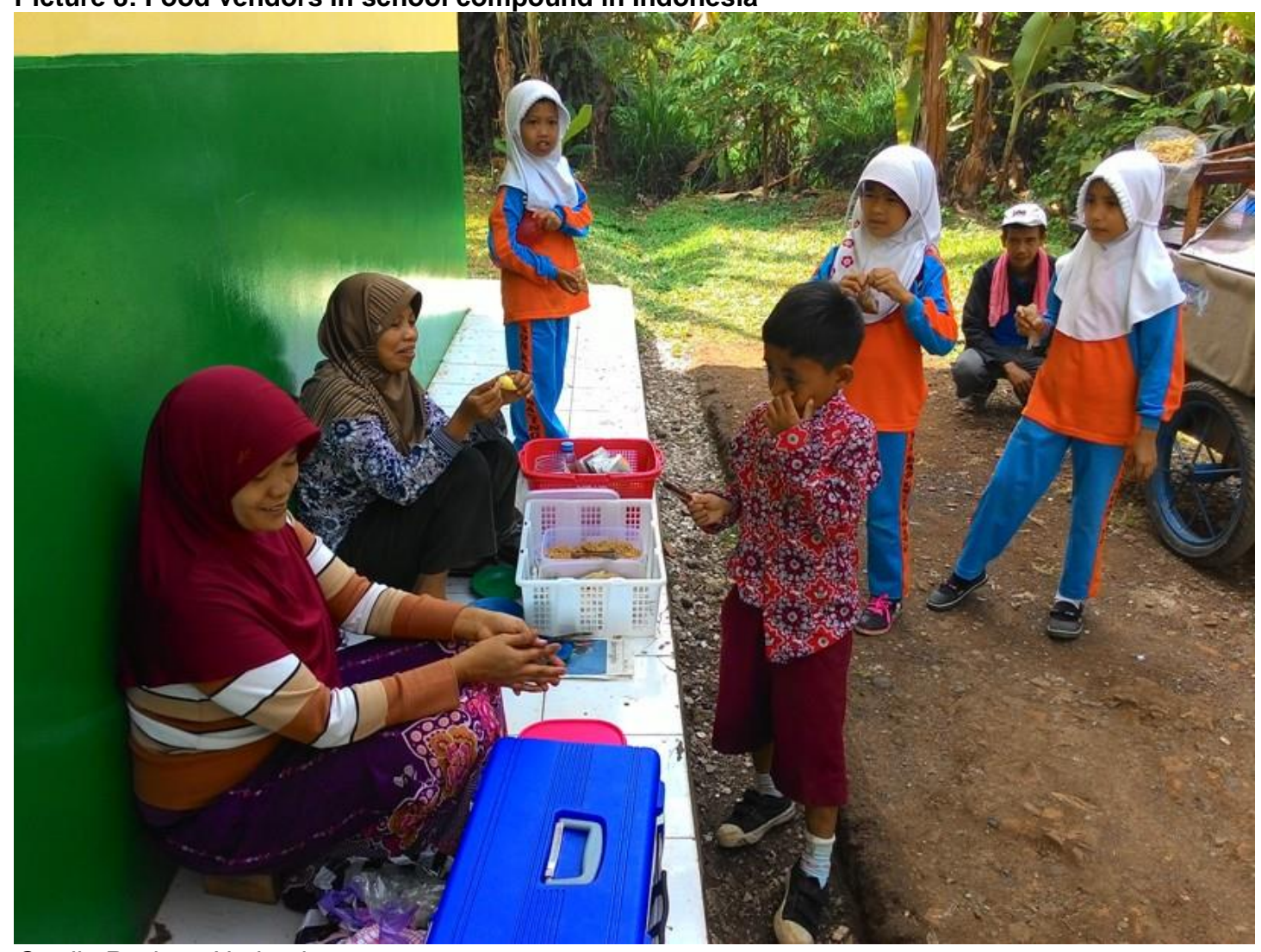

Credit: Rachma Nurbani 2014

It is not only local vendors whose wares appeal to children. The big global brands of packaged and processed food and beverages like coca cola and sprite, as well as more local brands of drinks, chocolates and sweets, chips and fried preparations are almost universally popular with children. Television advertising and marketing at children are factors. Mrs J., a 41-year-old landlady and domestic helper in Dhaka said: 'my grandson sometimes asks me to buy him choco-moko after watching television. I had never heard of it before'. Mrs R., the 36year-old wife of a Karachi police officer said that since her 3-year-old son started watching television he wants her to buy whatever food is advertised, such as instant noodles, Horlicks or Milo and even food being advertised by Indian television channels, such as Knorr noodles, which are not available in Pakistan. In Kami, Bolivia, many respondents referred to children 
and teenagers whose parents had migrated within Bolivia or abroad, who received remittances and consumed fast food almost exclusively.

Children are not the best judges of what constitutes good food, and they are prime targets for advertising and marketing campaigns, both by local vendors and the global food industry. In communities like these, in which processed and purchased foods are relatively new, advertising to children can be very powerful. In many of these settings, giving children snacks is understandably seen as a sign of indulgence and affection.

\subsection{Family and care}

I think that nowadays most people go to work and they do not have time to cook anymore. The easiest thing is to go out and buy the food already prepared. It is more due to lack of time and comfort. We have to take into account that the majority of women work nowadays. Before it was rare to see a woman working outside of the home; the women were supposed to stay at home. Now it is rare to see a woman who knows how to cook a good meal, and knows how to prepare a good sauce. Everything is easier, more practical. I think that even the technology has a lot to do even in the kitchen. Before to make a good recado (a special sauce) we had to grind the ingredients in a mortar, while now even the recados are being sold in a small ready-touse bag. Everything is pure chemical. Well, they are easier, comfortable and need little time, because if it is about economy, they are not cheap at all.

These words from a woman in Guatemala are pointing to new and shifting priorities. In several sites, we found that convenience, availability and time-saving trump concerns over nutrition and even cost. This is tied to the urban lifestyle, changing aspirations and the casualisation of labour, which leaves little time and/or energy for cooking. Few processed foods and fast or street foods are actually cheaper than equivalent home-cooked foods, but they are easier.

There is a clear link between the consumption of processed or ready-made foods and the way women's unpaid care work is changing in the family. Women are increasingly involved in paid work and, far from having unpaid care taken over by others in the household, find themselves squeezing unpaid care into what little time and energy is left over. In particular they are reducing the amount of time they spend cooking. For many it is a relief to cook less, or to be able to use part processed ingredients that speed up the preparation time. But they also worry about what it is doing to family and to nutrition and health and about the loss of respect for the skills and knowledge that they had brought to this aspect of care. One discourse that emerged from most sites was the idea that the move towards the consumption of processed foods at the household level stemmed from women's laziness and loss of knowledge of how to cook tasty and traditional dishes. Some women agree: Mrs S. of Lango Baya exclaimed:

I cannot buy these foods and take them to my family or even take my family to the hotel, it's unacceptable, I will be viewed as a lazy woman who is not able to cook for her family.

On the other hand, some men also recognise women's toil and welcome the changes in food habits. Thus the local chairman of Naogaon village, one of the rural Bangladesh sites, stated that:

The trouble of housewives is reduced due to the availability of outside foods. Before, I had seen those who made popcorn and chatpati (a spicy snack of pulses and 
vegetables) at home for guests. It was very difficult to make. But now people are not doing that. When guests are coming at home, they buy biscuits from outside and give those to eat.

In a mixed focus group discussion in Ethiopia, one participant pointed out: 'the fact that children eat outside reduce workload on the mothers. The time that a mother spends to prepare snacks is reduced significantly.' Women themselves, for the most part, welcome the availability of ready-made foods. Tellingly, in Lango Baya female farmers explained that it is mainly during the rainy season when lighting a fire in the morning is a struggle that they opt for outside foods. Similar stories were heard in Naogaon. In the urban site of Chichicastenango, Guatemala, Mrs J., a 20-year-old tortilla seller looked forward to further developments that would enable her to save time on cooking: 'time is advancing and people look for another way to do things more easily. ... maybe in the future there will be food that will only need to be reheated.' It is convenient to be able to give guests food bought from outside and in many cases this is not an embarrassment but a sign of status. For many younger people, new food cultures are one of the attractions that pulls them towards a new life in the cities: in Burkina, for example, the saying goes: 'it is the tô [sour dough of sorghum or millet] that kicked the youngster out of the village.'

Families used to be more close-knit because the mother didn't go out to work, she used to take care of the home, she was always at home. Now because of the crisis both parents go out to work. (...) It might be good for those households' income, and I expect they're obliged to from necessity, but I don't think it's a good thing. (Elderly woman, Bolivia) 
Picture 9: Tending to meat brochettes in Nessemtenga, Burkina Faso

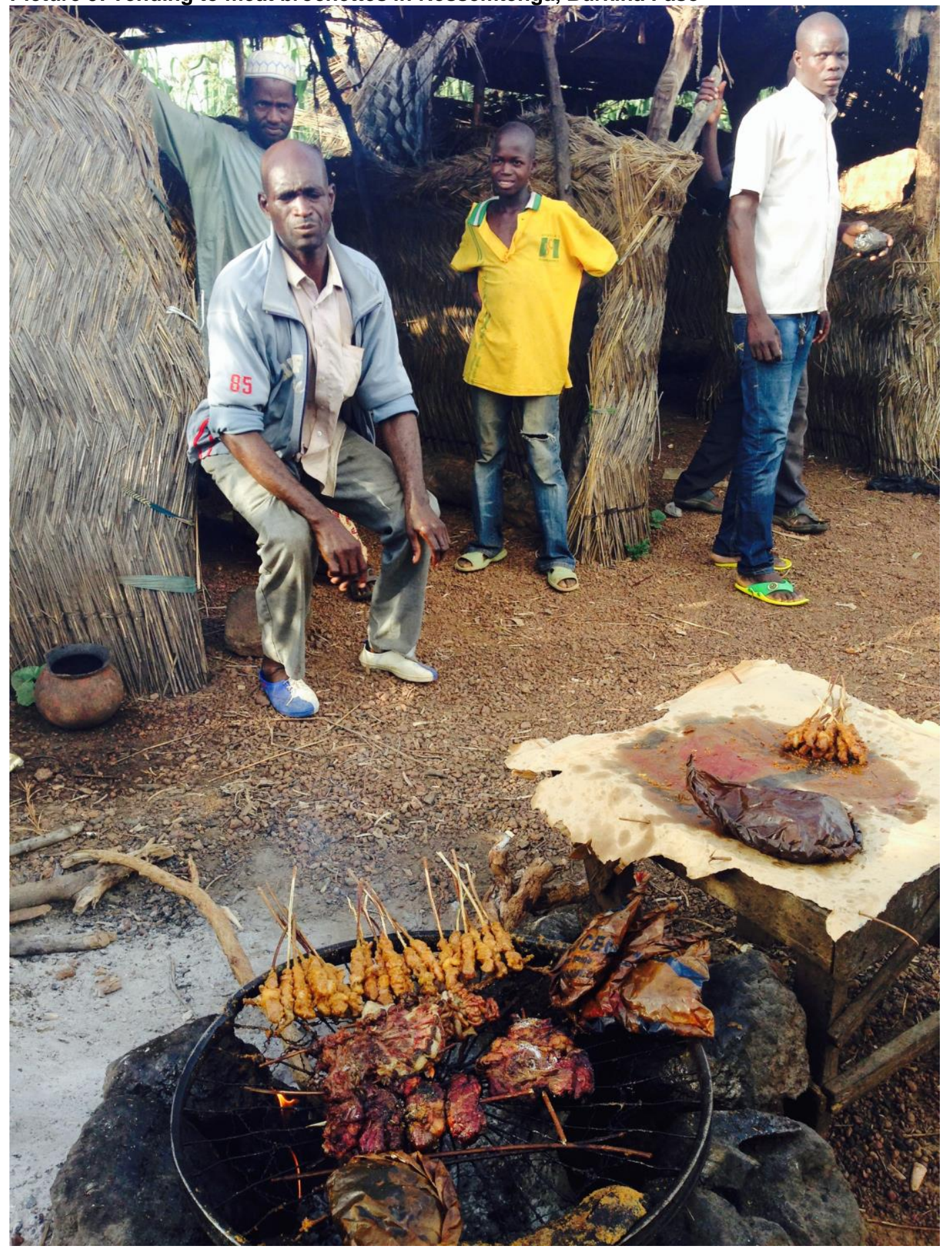

Credit: Alexandra Wanjiku Kelbert 2014

These tensions as to who gets to eat what meals were echoed in several other countries. In a focus group with women in Naogaon, Bangladesh, Mrs B., a 20-year-old housewife, lamented that: 'if husbands take foods in the bazaar according to their wish then what would they feed their wives and children?' Similarly, in a discussion in Mukuru with female heads of household, one argued that:

Meat is mostly consumed by men. This is because for us women, we would not go out to eat meat when our children do not have food at home. We would rather use that money to buy kale and have it with our children. 
Likewise in Bolivia, pensioner Mrs P., aged 73, explained how pork and, in particular, readycooked pork is not good value for money:

Buying ready-cooked food is expensive. A plate of pressed pork costs 70 (10 dollars), fried pork 100 (14 dollars). For that money l'm better off cooking for everyone and we eat better as a family here at home.

Mrs C., 40-year-old farmer and community leader in Pirhuas, Bolivia went into more detail:

It works out expensive for the whole family. It's Bs.8.00 for each basket, and it's only a small piece of chicken, it's mostly chips. There are seven of us, 7 times eight is Bs.56, plus the drinks, it's expensive to buy food in the street. I cook the same with a whole big chicken (21/2 kilos) for Bs.37.00, with big portions...

And Mrs L. a 63-year-old weaver in Chugüexá Primero, Guatemala spoke about how home cooking can help extend the number of meals: 'when we buy already prepared food the portions are too small and only for one mealtime. But when we cook at home sometimes there are leftovers for dinner and that way we can save a little.' 


\section{BAD FOOD}

\subsection{What are people worrying about?}

Even as they enjoy the taste and variety, people worry about safety, health and the effect on their families of the new food cultures. Food preparation practices that people find disgusting might lead to gastroenteritis or food poisoning, but the longer-term health consequences of diets containing many calorie-dense sugary and fatty drinks and snacks are also of great concern. That they are a distant problem does not mean people are not wary of them hypertension, diabetes, cancer and shorter lifespans were mentioned in almost every country as the effects of eating highly processed fatty and sugary foods, particularly in Bolivia and Guatemala, where processed foods appear to be more important in local diets and a matter of greater concern. Many older people comment on the difference between home-cooked and street food. Mr QG., a 50-year-old social worker at the health centre in the market town Chichicastenango in Guatemala explained that in his view the dangers of 'natural' foods are less serious than those of processed street foods:

Fried potatoes, chicken, tortillas, the ones being sold on the food carts on the street, the tortillas with meat that you know that are being sold there, and basically the little bags of corn fritters, all of them, because they are junk food and I think that all of these already processed foods would never be like when I eat some vegetables which are not processed. Although maybe they have some bacteria and if they are not properly cleaned well I could get sick with some amoebas, but it is still natural.

Picture 10: Branded and unbranded goods in Kaya, Burkina Faso

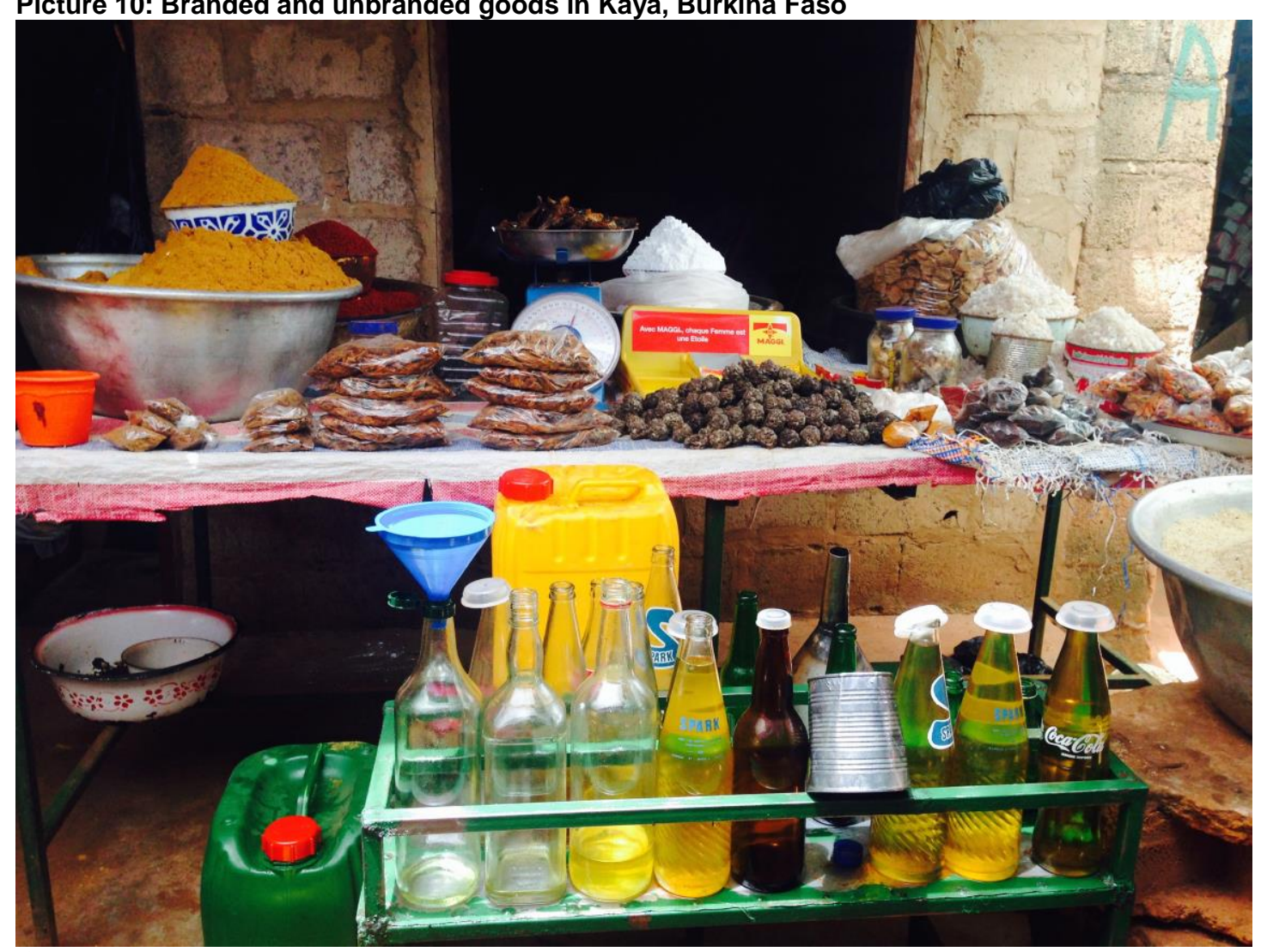

Credit: Alexandra Wanjiku Kelbert 2014 
Teenage girls in Sachal Goth, in Karachi in Pakistan, explained that buying non-branded goods for foods that can be adulterated with ease is risky. They said oil such as the Mezan brand $^{7}$ sells for high prices whereas oil sold in open containers (or in the customer's own container) is cheaper and of poorer quality. This is because the branded oil is packed whereas open oil is unclean and contains impurities; sometimes they find insects in it. One girl thought that low quality oil affects health and is responsible for breathing problems. Another noted that when they complained about the quality of cooking oil, shopkeepers say that: 'if you want good quality then you should pay high prices'. We heard the same story in Zambia and Burkina Faso.

Attractively wrapped and branded products from big name companies, in sealed packets that appear pristinely clean and hygienic have some major advantages over locally processed and cooked foods, not least because they are often backed by massive marketing and advertising campaigns. Branded goods from big companies do not always have the edge in terms of safety over local foods - the 'known knowns' of problems with local diets can be at least manageable, whereas the branded products often contain obscure ingredients or excessive fats and salts. Nonetheless, the fact of apparently hygienic packaging, the use-by dates and the assurance that comes with buying a known name (presumably because so many consumers could not be wrong) are factors in giving branded foods the definite edge over cheaper open, non-branded items. Even then it is possible to fake brands, as people who had bought what they thought was the fine fragrant Pandan Wangi variety of rice were actually duped into buying an inferior grain in Cianjur, in West Java in Indonesia.

Table 1 shows the worries expressed by people in each of the 23 sites. Some of these are genuine causes for concern, others are mysterious and others (fingers, cats and rats) may be urban myths. Regardless of whether or not people are right to have these feelings about the food they increasingly eat, they report such feelings. The degree of disgust and fear in the ways people talk about the food they eat reflects over and again a sense of loss of knowledge and control about one of the most important aspects of daily life.

Table 1: Disgusting and dangerous food

\begin{tabular}{|c|c|}
\hline Bolivia & $\begin{array}{l}\text { Don't eat the chicken caldo - 'mother says cheapest chunks of chicken } \\
\text { going in, but poor people eat it' } \\
\text { Sausages are made from donkey or dog meat or whatever, and they } \\
\text { put in loads of condiments - garlic, cumin, pepper, grated papaya, } \\
\text { ajinomoto, paprika - to make them taste good } \\
\text { Pork has trichina disease } \\
\text { Street foods cooked in old or burned oil } \\
\text { Serving 'dead chickens' - i.e. carcasses of animals that died of } \\
\text { unknown causes } \\
\text { Washing chickens with bleach } \\
\text { Unwashed potatoes } \\
\text { Cheapest cuts of chicken } \\
\text { Extra fat to make the chicken caldo taste good } \\
\text { Bought chicken that was raw inside, burned outside } \\
\text { Fried chicken is cooked in so much oil that it is basically just oil inside }\end{array}$ \\
\hline Guatemala & $\begin{array}{l}\text { Too many sodas cause diabetes } \\
\text { Consommé is dangerous - too much salt } \\
\text { The junk food such as tacos, gringas, they are not healthy and are } \\
\text { being eaten frequently; and they are right there attractive, cheap and }\end{array}$ \\
\hline
\end{tabular}




\begin{tabular}{|c|c|}
\hline & $\begin{array}{l}\text { we eat them. They use lots of cooking oil which is recycled } \\
\text { Fried chicken and fried potatoes cooked in old oil } \\
\text { Bad tamales } \\
\text { Tinned food gives you lead poisoning } \\
\text { Canned food, sausages }\end{array}$ \\
\hline Burkina Faso & $\begin{array}{l}\text { Beans (cooked with carbide) } \\
\text { Things cooked in bad old oil } \\
\text { Chemicals in sauces, including fake tomato } \\
\text { Maggi® cubes } 8 \text { in the Soumbala cooking process } \\
\text { Wheat pancakes cooked without hygiene } \\
\text { Canned sardines - don't know the process, what kind of fish }\end{array}$ \\
\hline Ethiopia & $\begin{array}{l}\text { Potato chips, biscuits and samosa cooked in old oil } \\
\text { Packaged juices - don't know what goes into them } \\
\text { Old (bad) lentils in samosas }\end{array}$ \\
\hline Kenya & $\begin{array}{l}\text { Mixing old food with fresh food } \\
\text { They also pointed out that there are some traders who use Magadi } \\
\text { (soda ash) while boiling beans which is not good for the stomach } \\
\text { Touching food with dirty hands } \\
\text { Adding colour to fried potatoes } \\
\text { The samosas are not safe. You do not even know how they have been } \\
\text { prepared. Sometimes we think they are made of cat meat since there } \\
\text { are many cats in this area and no one would notice if one was missing. } \\
\text { 'I do not eat samosas anymore. On two occasions I have found a } \\
\text { cockroach and a rat's tail in the samosas.' } \\
\text { Sweating and wiping hands into chapatti dough } \\
\text { Uncooked chicken neck sold as cooked } \\
\text { Chicken head and neck padded out with a potato } \\
\text { Bad cooking oil } \\
\text { Chicken legs come in different colours } \\
\text { Hairs in food } \\
\text { Soda ash (baking soda) to make githeri cook faster }\end{array}$ \\
\hline Zambia & $\begin{array}{l}\text { Goat and pork slaughtered unhygienically } \\
\text { Yes we are eating dagaa which is very cheap but bad for the health. It } \\
\text { contains a lot of sand, very smelly and it's bitter } \\
\text { Some vegetables are sold without waiting for the pesticide to expire. } \\
\text { So when the vegetables are sold and we buy, they tend not to be tasty } \\
\text { and after eating most of the household members complain of stomach } \\
\text { upsets leading to diarrhoea in some cases } \\
\text { Pies and samosas kept overnight and go off } \\
\text { Too much oil }\end{array}$ \\
\hline Bangladesh & $\begin{array}{l}\text { Food left uncovered, open to the dust and street filth } \\
\text { Stale sweets left uncovered, covered in flies } \\
\text { Food cooked in burned oil } \\
\text { Unhygienically prepared tea on street stalls, and fake condensed milk } \\
\text { Khai shoda used in food which is bad } \\
\text { Well-known restaurants use 'dead chickens' }\end{array}$ \\
\hline
\end{tabular}




\begin{tabular}{|c|c|}
\hline & Commercial (not food) dyes \\
\hline \multirow[t]{7}{*}{ Indonesia } & $\begin{array}{l}\text { When they see crackers with beautiful colour, they will usually say 'it is } \\
\text { clean and fresh, right'. They actually do not know what it is used for } \\
\text { colouring it. Me myself, although I know it, I still buy it. }\end{array}$ \\
\hline & $\begin{array}{l}\text { 'If the colour is weird, I am afraid (to buy it). If the colour of shrimp } \\
\text { paste is bright red, it is weird, isn't it?' }\end{array}$ \\
\hline & $\begin{array}{l}\text { Bought sauces are not healthy since many children got stomach pain } \\
\text { and heartburn since the chilli was not clean or was fake }\end{array}$ \\
\hline & $\begin{array}{l}\text { There are foods that use preservative, for example tofu, it looks } \\
\text { healthy, but we do not know if it contains formalin or not }\end{array}$ \\
\hline & $\begin{array}{l}\text { Fried snacks from vendors are also not clean, for instance, the cooking } \\
\text { oil has been used two or three times }\end{array}$ \\
\hline & $\begin{array}{l}\text { People buy cookies cakes, etc. packaged and don't look at the expiry } \\
\text { date }\end{array}$ \\
\hline & $\begin{array}{l}\text { Meatballs made with formalin, and children's snacks using non-food } \\
\text { colouring ingredients and interesting packaging }\end{array}$ \\
\hline \multirow[t]{6}{*}{ Pakistan } & Dead animals cooked with tasty spices \\
\hline & $\begin{array}{l}\text { Some of the respondents said in hotels in big cities these days, dead } \\
\text { animals are being cooked with tasty spices such that the people enjoy } \\
\text { the food thoroughly and don't realise that it is the meat of a long-dead } \\
\text { animal }\end{array}$ \\
\hline & $\begin{array}{l}\text { One respondent said that he was eating in a restaurant in Karachi once } \\
\text { and found the finger of a human being in the food }\end{array}$ \\
\hline & Soda in the roti \\
\hline & Outside food cooked in stale and bad oil \\
\hline & $\begin{array}{l}\text { Stopped buying fresh milk after saw a milk seller straining the milk for } \\
\text { flies }\end{array}$ \\
\hline \multirow[t]{6}{*}{ Vietnam } & $\begin{array}{l}\text { There was a person who sold products from meat preserved for long } \\
\text { days and having no clear origin }\end{array}$ \\
\hline & Don't buy cooking oil in bulk - might be recycled \\
\hline & Pesticides on veg, pork from too young pigs \\
\hline & Poisoning from cooked rice next to mosquito sprayers \\
\hline & Meat of animals reared using growth stimulants often stinks \\
\hline & Chicken shrank after cooking \\
\hline
\end{tabular}

Source: Authors' own.

\subsection{Food production}

For people like the agricultural labourers in Ethiopia, the motorcycle taxi riders in Kenya or the rickshaw-pullers in Bangladesh who have money but no kitchen, the spread of eateries is a boon. But even as many people talk of the benefits, the majority also talk about their worries about how these foods are produced. A participant in a focus group discussion with men in Dadu, rural Pakistan said, for instance, 'in the past, food was richer and real, for example lassi (yoghurt drink), butter, ghee and milk.'

Even though many people, particularly those in rural areas, still eat a diet consisting mainly of fresh vegetables, local grains and meat, they worry about the effects of increasing amounts of pesticides, herbicide, fertiliser and hormones. Market gardeners in Zambia, for example, know the amount of chemicals that they have to use to get their crops to grow well and compete in the increasingly crowded market full of perfect-looking green leafy kale and red 
tomatoes. They also know that they often spray closer to the time of harvest than is recommended. The same worries turn up in many countries. In the village of Nghe An in Vietnam, a farmer explained, 'today, people are using too much pesticide; its use is rampant, people do not follow the instructions, especially for vegetables and rice. But, if it is not used, there will be no harvest, so people have no choice.' Meanwhile, a 43-year-old female householder in Hanoi, explained:

I only buy vegetables with poor appearance. If the vegetables are good-looking, we dare not to buy. At this time, pak choi and sweet leaf bush need to use much pesticides.

In Bolivia and Zambia there are worries about hormones pumped into meat, while in Burkina Faso people living near a mining area spoke of their concerns that livestock were drinking from cyanide-polluted water sources. A woman in Pirhuas, Bolivia who used to work in a chicken packing factory said, 'the factory-farmed chicken is bad. We worked in those farms for six years and we know they inject them every day with hormones, and that's bad for you.'

In Kabwata, Zambia, a woman divorcee said:

It is not normal for a chicken to grow in six weeks, but we eat the chicken anyway. I hear they are now putting anti-retroviral drugs in the chicken feed so that they grow big and can be sold at a high price.

\subsection{Additives}

In every country there are anxieties about adulterants. In Burkina, it is common to hear talk of carbide used for cooking peas, while in Kenya unscrupulous restaurateurs are accused of using sodium carbonate to reduce the cooking time of maharagwe kidney beans. In Bangladesh and Indonesia there is widespread media coverage of scares about formalin, apparently used to preserve vegetables, fruit and fish, while in Vietnam and Indonesia people worry about the use of borax, a common but forbidden additive to noodles and rice. People wish that their food was not dyed, bleached and preserved, but mostly they continue to eat it.

In Guatemala, one woman suspected that the consommé powder is made from contaminated chicken, and almost everyone was suspicious of it as a source of ill-health. In Kenya, however, people are not worried about the widespread use of Royco (also known as Royco Mchuzi Mix $\left.{ }^{9}\right)^{9}$ and other monosodium glutamate powders. In Indonesia there is a fairly sophisticated debate about food additives and considerable concern about colouring, artificial sweeteners and flavour enhancers. A health worker in Cianjur, Indonesia observed:

Some community members know that foods contained preservative, food colouring and artificial sweeteners are not safe for child health, but parents still buys snacks for their children with an excuse that the children will not stop crying unless they get the snacks they want.

\subsection{Hygiene}

Many people, particularly those in places where food inspection is insufficient, worry about unhygienic food leading to food poisoning and stomach problems. Fast food kiosks by the roadsides have little defence against dust and flies and proprietors are widely accused of using dirty water and having low regard for hygiene. They, and packed food manufacturers, are suspected of purveying refrozen, old, rotten, past-sell-by-date and often suspiciously cheap food. At every site people spoke repeatedly about their fears of recycled cooking oil. In Bolivia and Guatemala, for example, there were numerous tales of cooking oil used over and 
over for fritters until it turned black and rancid. One of a group of women in urban Addis Ababa described her thoughts about how street food is prepared: 'the place where the foods are prepare is not clean; it has flies, bad smelling odours, crowded people and unsafe sewage systems.' In Kenya too, there are worries, as expressed by one young man in Mukuru: 'the deep-fried foods such as chips and mandazi are prepared using cooking oil that is so dark due to recycling and there is a rumour that that oil is mixed with that stolen from electric transformer.'

\subsection{Health and nutrition}

Parents worry that their children are getting the wrong kinds of nutrition, endangering their strength, intellect and health. In Indonesia and Bangladesh, parents are concerned about excessive sugar and several report how they pack their children's lunchboxes with fruit and other more healthy substitutes. They explain that children become addicted to fast foods, lose their appetite for more nutritious food and become hard to control.

Everyone we talked to had a strong sense of the benefits of good nutrition and safe food. In Bolivia and Guatemala good food is associated with a long life. Older people felt that today people were not living so long, though they couldn't be sure if it was food or stress that was causing the problem. In Ethiopia parents worried about how their children's strength seemed to be reducing, even as they seemed to be eating more. In Guatemala one father observed that he felt that intellectual development might be impaired if his children persisted in eating the low nutrition foods that they could buy in and around the schoolyard, while in Pakistan older women pointed out that younger women had less strength in childbirth than they once had.

A fairly consistent list of diseases and deficiencies that people think are the consequences of eating bad food emerged from across the different sites. In Bolivia older women explained that diseases that had once been common are now controlled by medicines, but they have been replaced by problems like diabetes, ulcers, appendicitis, cancer, breathing problems and high blood pressure, all of which can be put down to poor diet. In Chichicastenango Guatemala, a government health worker gave his version of the diabetes problem:

Over there in the community where I live, many young people have already had surgery to take out their appendix and there are many people with diabetes. Why can this be? Before people did not consume much sugar, they only used natural brown sugar because it is good and natural.

\subsection{Changing relationships}

There are fears that the changing food habits are weakening family bonds and changing social networks in several of the sites. 'Children', said one person, are 'manipulated by the market and the TV advertisements.' When children eat snacks on their way to and from school and when family members eat at kiosks rather than at home, the more traditional among them worry that they are losing their culture and their ability to exert family discipline and good behaviour.

In addition, some report worries about changes to the way their social networks function, many of which have food at the centre. Changes to how people eat mean change for the social as well as the physical body. In Ethiopia, people explained how they would no longer go to funerals because they could not afford to bring the right kinds of food. In Pakistan, women householders worried when they gave guests items to eat that had come from the market rather than from their own kitchen. While not many people spoke of the positive sides 
of changing family life, some men (but not women) spoke, for example, of how men are learning to share the food preparation duties with women, for instance in Ethiopia. But also in Ethiopia, urban women in a focus group discussed the difficulties that can develop. One of them said, 'there can be family problems to the extent of divorce might happen because children and men members of the family would like more money for these food habits.'

In many cases parents say they have lost some control over the nourishment of their children, since they cannot oversee what children eat at school and many mothers are no longer so much at home, but outside earning an income. Perhaps an eternal complaint, but seemingly a growing concern, parents explain that children become addicted to sweets and are attracted by bright packaging. They worry too how easily they are influenced by television adverts directed at them and how parental discipline is so often challenged.

\subsection{Who is protecting us against bad food?}

Parents in Bangladesh, Burkina Faso, Indonesia and Pakistan all spoke of trying to advise their children, but their children do not listen. In Bangladesh adults warn their children that ices may be made with dirty water; in Indonesia, they try to explain that money is short and snacks are too costly. But children pay little heed, parents tell us. At home and school parents and teachers speak to children about their health, not only about stomach-aches but about long-term problems that can come from eating badly. In Ethiopia one father is stern; he says it is important to discipline children from a young age and forbid junk food in the house. In a Bolivian neighbourhood, a Catholic pastor speaks against junk food from the pulpit, while health workers on home visits and school nutritionists advise mothers about hygiene and nutrition. Health workers in Guatemala give demonstrations at the market of the nastiness of bad food to parents. In Indonesia a man admonishes his children not to believe the adverts on TV. There is a sense that despite their worries, a fair proportion of adults feel unable to stop their children or themselves from doing what they think may be dangerous to their health, strength and longevity. In part they are not sure how grave a problem it is and, in most countries, they do not feel supported by the authorities.

We heard about many different ways of dealing with the problem. Many mothers make efforts to make children eat enough of what they consider the right food at home. In Bangladesh a group of mothers explain how they make as much fruit available as they can and cook snacks for school or work which may be fried, sweet or salty, but are at least made of known ingredients. In Vietnam mothers take precautions in cooking, washing vegetables, soaking and pre-boiling meat, even going so far as buying expensive 'ozone' machines for removing pollutants from food. In Bolivia, some mothers make a special effort to teach children to cook.

Fathers in Indonesia and Pakistan spoke of limiting pocket money, while in Indonesia parents relied on teachers to oversee what children were buying at kiosks in the schoolyard. In Ethiopia, some parents said they no longer send children to the market on errands. Adults also said that it was important to set an example, of eating at home without Maggi (in Burkina Faso), eating with herbs and not packets (in Guatemala), and raising chickens and vegetables at home without pesticides and hormones (in Pakistan).

Some try to buy branded items since they appear more reliable and some try to buy from supermarkets which appear cleaner than market stalls. In Bolivia, women talk of buying known brands, reading the ingredients on the packet and checking sell-by dates. The Vietnamese suggest that one should avoid brightly coloured packaging and even bright coloured vegetables. In Burkina, Kenya and Zambia, people are relying on their ability to assess good quality food in the market and to avoid items like fish that are too cheap and known to cause problems. In urban sites a few men mentioned the necessity of carrying 
antacids around in your pocket. Meanwhile, consumers often complain directly to restaurants and stall-holders, taking food back when it is not up to standard, but quite a few people, particularly urban dwellers, said that bad food cannot be avoided and there is nothing to be done.

All countries make efforts through governmental and non-governmental organisations to inform people about nutrition and food-related health. There are consumer associations, UN agencies, NGOs, government campaigns on the TV and radio (and on the loudspeakers on every corner in Vietnam), leaflets, courses and extension services, covering nutrition, safe farming, adulteration and safe storage and cooking. The level and form of information provision varies, from detailed in Indonesia, to alarmist in Bangladesh, to moral and holistic in Bolivia where there is teacher training on ancestral foods and traditional food fairs.

In the levels of attention and responsibility taken by government we saw, perhaps, the greatest variation between the ten countries. In the communities we visited, people's understanding of and satisfaction with questions of food safety and quality are much influenced by government. In all countries there are food inspectors, but whereas in Burkina Faso, Kenya and Bolivia they are deemed largely decorative, and in Bangladesh they are said to be too easily turned with a bribe, in Indonesia the advisory and food safety inspection regime is seen as comparatively thorough. Thus parents have more detailed understanding in Indonesia than they do in, for example, Kenya and businesses are more often subject to controls. Food safety regimes notwithstanding, in Vietnam, where there is an active inspectorate, there is a sense that abuse is managing to slip past the inspectors.

Once premises have been identified as breaching regulations, our focus groups in Burkina Faso and Bangladesh believed that the seller often responds by making improvements. But in Bangladesh we also heard how sellers simply disappear, reappearing later in a new guise. In Pakistan sellers apparently pay little or no attention to the inspectors' orders, whereas in Vietnam officials will impose statutory penalties and follow up to make sure changes are made. Vietnam requires certified meat and clear labelling, while Indonesia has a system of business licensing in relation to hygiene and food safety. Conversely, in Bolivia it depends on the local mayor. The mayor may decide to engage in a food safety campaign in a bid for the votes of the consumer, or underplay food safety in a bid for the votes of the vendors and producers. In many countries schools take some responsibility for controlling what pupils are eating and in some cases provide nutrition education. In Indonesia, Ethiopia and Guatemala school principals explain how they monitor and control snack vendors within the schoolyards. Government-sponsored school-feeding programmes that aim to provide calories can sometimes fall into the problem of providing unhealthy foods, however. A programme in Bolivia, for instance, supplies sugary drinking yoghurts and fortified candy to schoolchildren. Overall, there is still a strong sense among citizens that governments do not do much to control the spread of dangerous food, whether in the form of education or protection.

\subsection{What do people think should be done?}

Many parents would like more information to allow them to evaluate scare stories and to make good decisions about their own and their family's food. In Ethiopia, men wanted their government to ban roadside selling and to do more to regulate and provide for effective sanitation. In Bolivia and Guatemala, mothers suggested that food safety, cooking and nutrition ought to be taught at school. In Burkina Faso and Vietnam, working men said they thought their government ought to be banning dangerous imported foods and flavour enhancers. But in the final analysis, most of the people we talked to in most countries thought it was probably going to have to be the consumers who did most of the work to protect 
themselves and their families from the negative effects of fast foods and fake foods. Few had faith that governments would be able to do enough or that corporations and business people would not try to evade the rules.

The effects of such new ways of eating are already known in the form of the 'stuffed' or obesity epidemic of the industrialised West (Patel 2012). Proposals to improve nutrition should be aware of the market forces behind the rapid transition from undernutrition to overnutrition or malnutrition, and the products and their producers that shape these markets (Lobstein et al. 2015: 6). What we see on the ground in these 23 communities would lead us to agree with experts that a closer look at the forces shaping food supplies is needed to tackle both undernutrition and overnutrition, as well as hygiene and health and issues of care and family relations. 


\section{SECTION 2: FOOD PRICE MOVEMENTS IN 2014}

Local and global food prices were generally less volatile in 2014 than they have been in recent years. The downward trend in international cereal prices was reflected in several countries, though not uniformly. However, food and general inflation continue to make life difficult for many households and the cost of the minimum food basket continues to be well above the five-year average.

\section{WORLD FOOD PRICES}

Global food prices fell significantly in 2014 , returning to levels not seen since 2010 . The FAO Food Price Index finished the year 20 per cent below its peak in February 2011 and the World Bank index recorded similar falls (Figure 2). These aggregate changes do, however, mask differences across food types; the FAO sugar index rose noticeably in the first half of the year before falling back in the second half of the year, while meat prices reached record levels in August. The FAO cereals and oils indices charted similar falls to the composite food index (Figure 3). Staple crops, core to human diets in most developing countries, all - with the exception of rice - followed a similar downward trajectory through most of 2014, though prices did rally in the last quarter before resuming their fall in early 2015. The price of crude oil, a key factor in the prices of agricultural goods, fell precipitously in the second half of the year. By January 2015 the oil price was under US $\$ 50$ per barrel, less than half its value just six months earlier (Figure 4).

Figure 2: Food price indices decline markedly in 2014

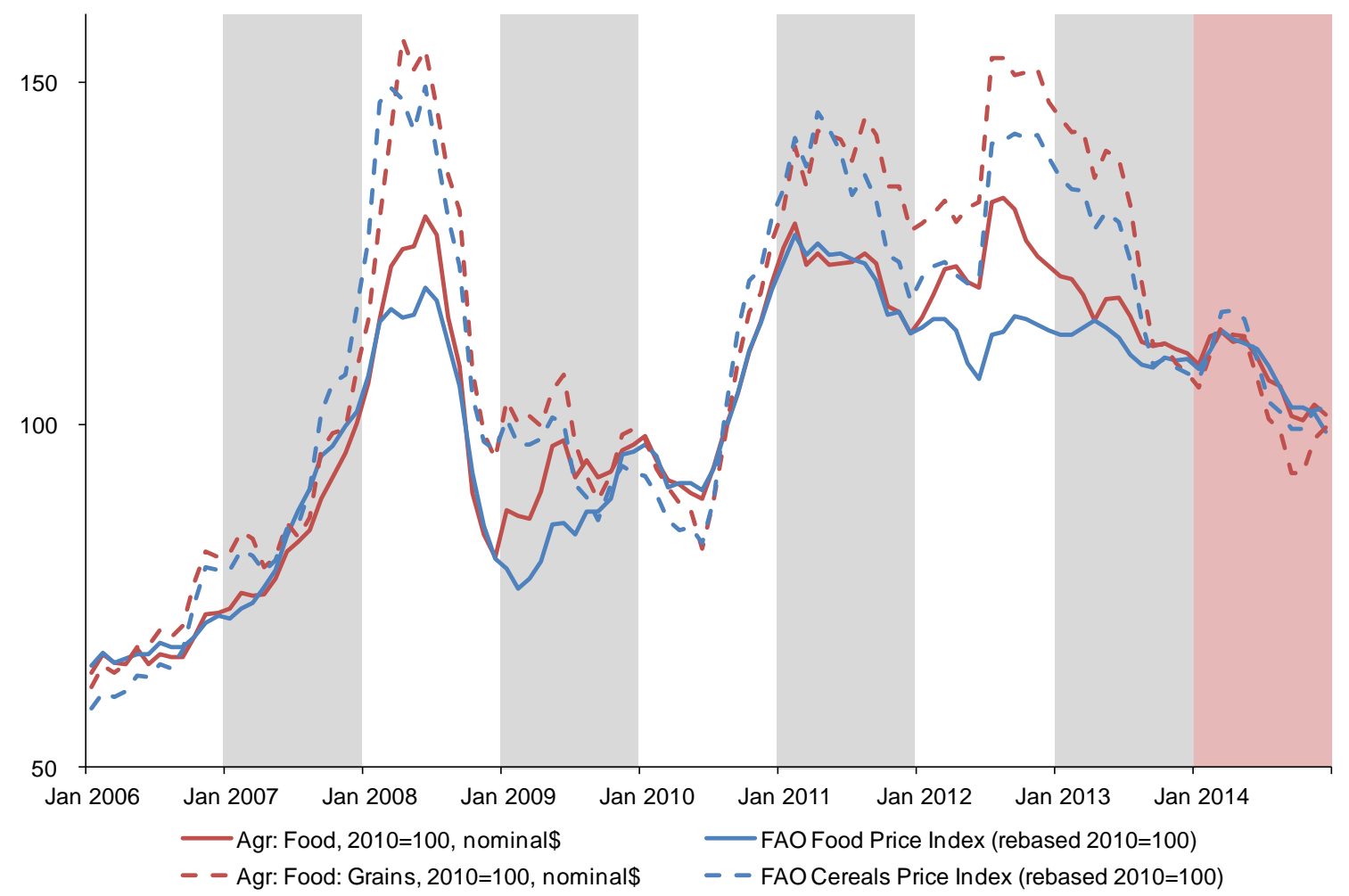

Source: FAO Food Price Index, www.fao.org/worldfoodsituation/foodpricesindex/en/; and World Bank, http://databank.worldbank.org/ 
Figure 3: Most food price indices fell in 2014, with the exception of meat and sugar

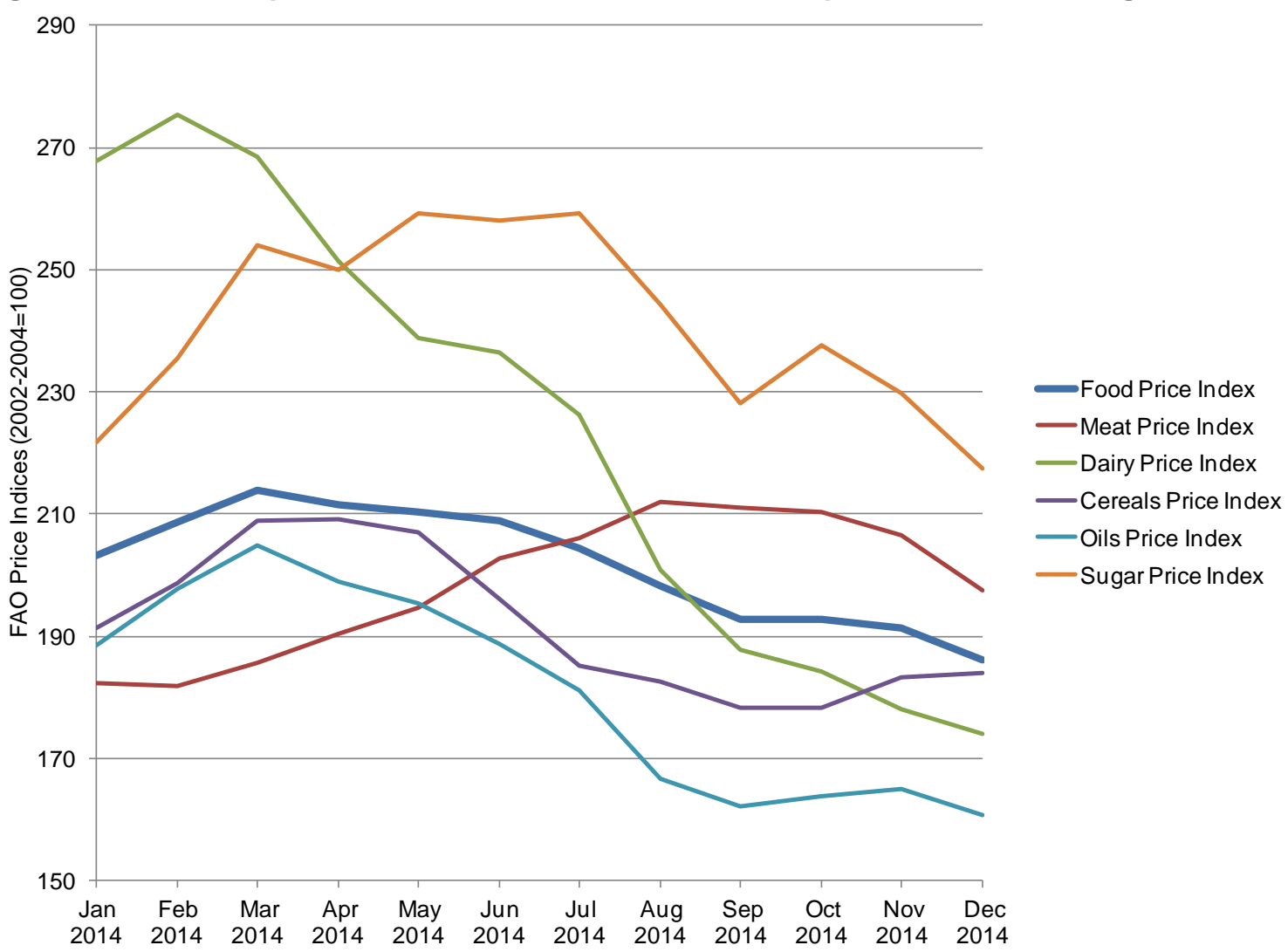

Source: Authors' own.

Figure 4: World staples and crude oil prices fell sharply for most of 2014, mixed picture for rice

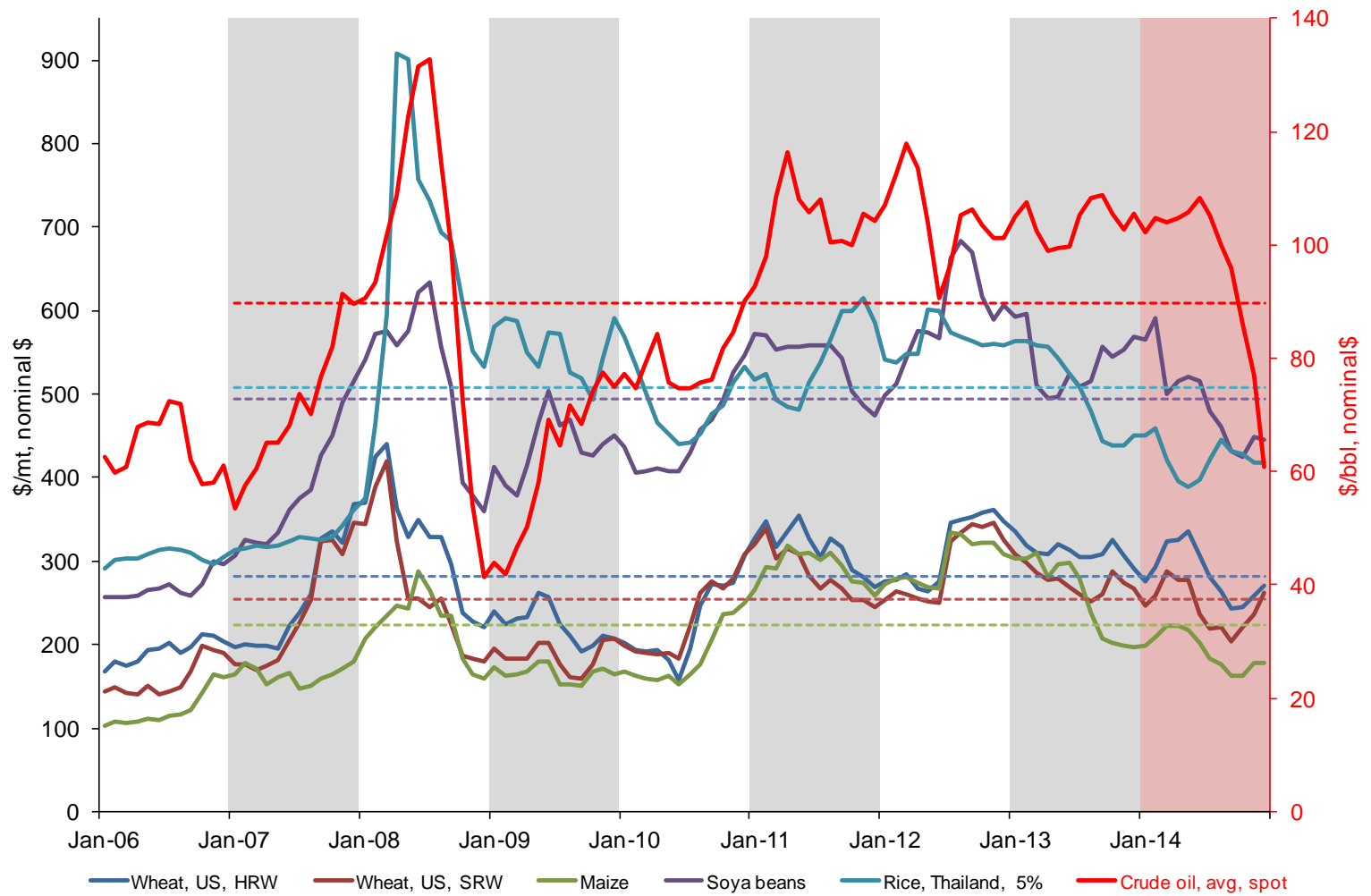

Note: Dotted lines: 2007-2014 average prices.

Source: World Bank, http://databank.worldbank.org/ 
Not only did prices decline to levels lower than in recent years, they also continued to be less volatile than in the period around the turn of the decade. At the end of 2014 IFPRI's early warning system had recorded at least 830 days of continuously low volatility for prices of the five staple food commodities that it tracks on the Chicago Board of Trade (hard and soft wheat, maize, rice, soya beans). ${ }^{10}$

Food prices in 2014 remained higher than at any point prior to the 2007-8 global food crisis (since 1990), but in real terms at the end of 2014 they were no longer dramatically elevated (Figure 5). In the absence of supply shocks, the OECD and FAO expect international prices of major crops to continue to decline slightly for a few years and then stabilise at similar levels to now (Figure 6). ${ }^{11}$

Figure 5: Real and nominal food prices remain high in historical terms, but no longer dramatically so

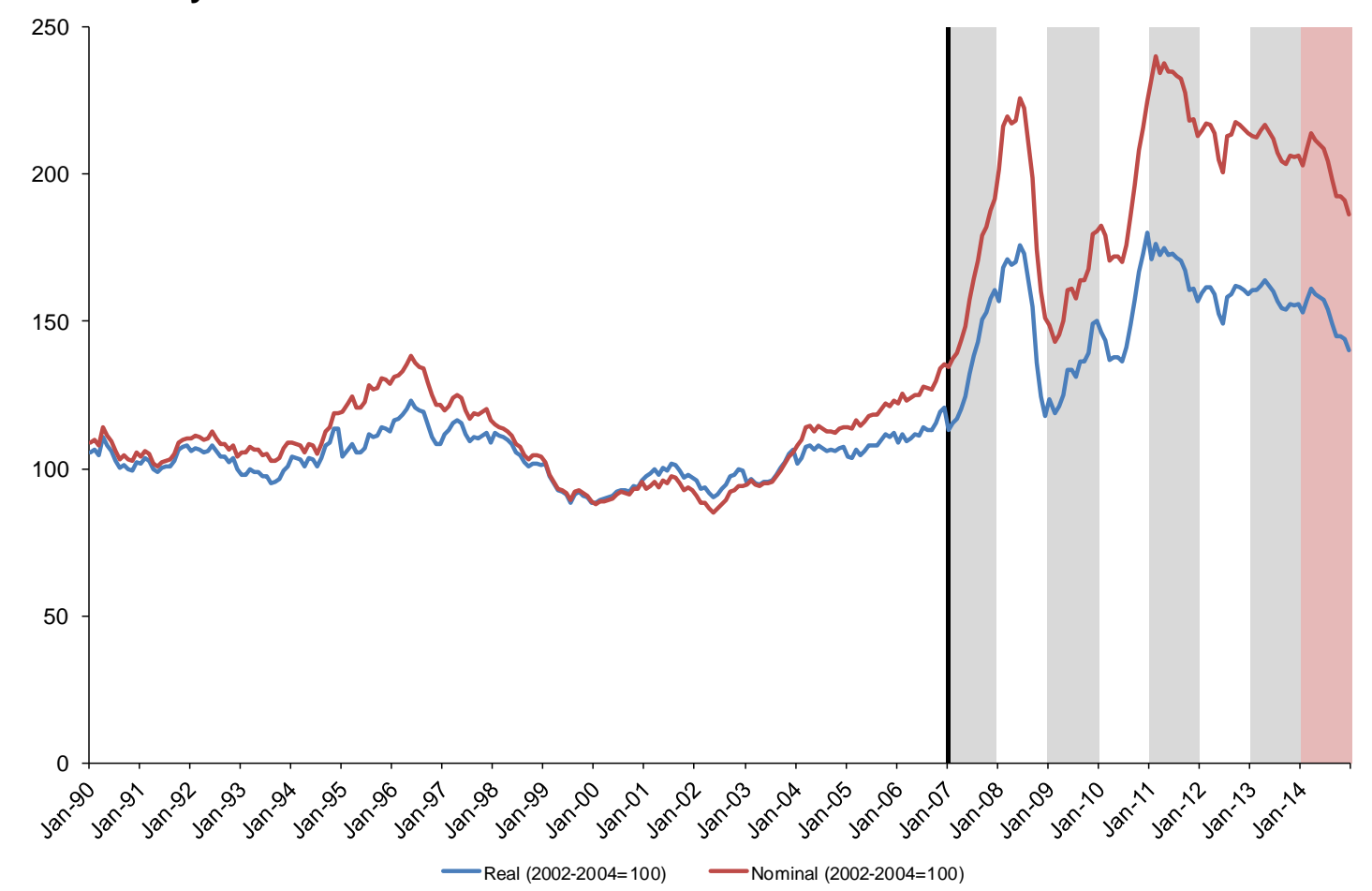

Source: FAO Food Price Index, www.fao.org/worldfoodsituation/foodpricesindex/en/

Figure 6: Cereal prices projected to fall over the medium term. Prices expressed in nominal (left) and real terms (right)
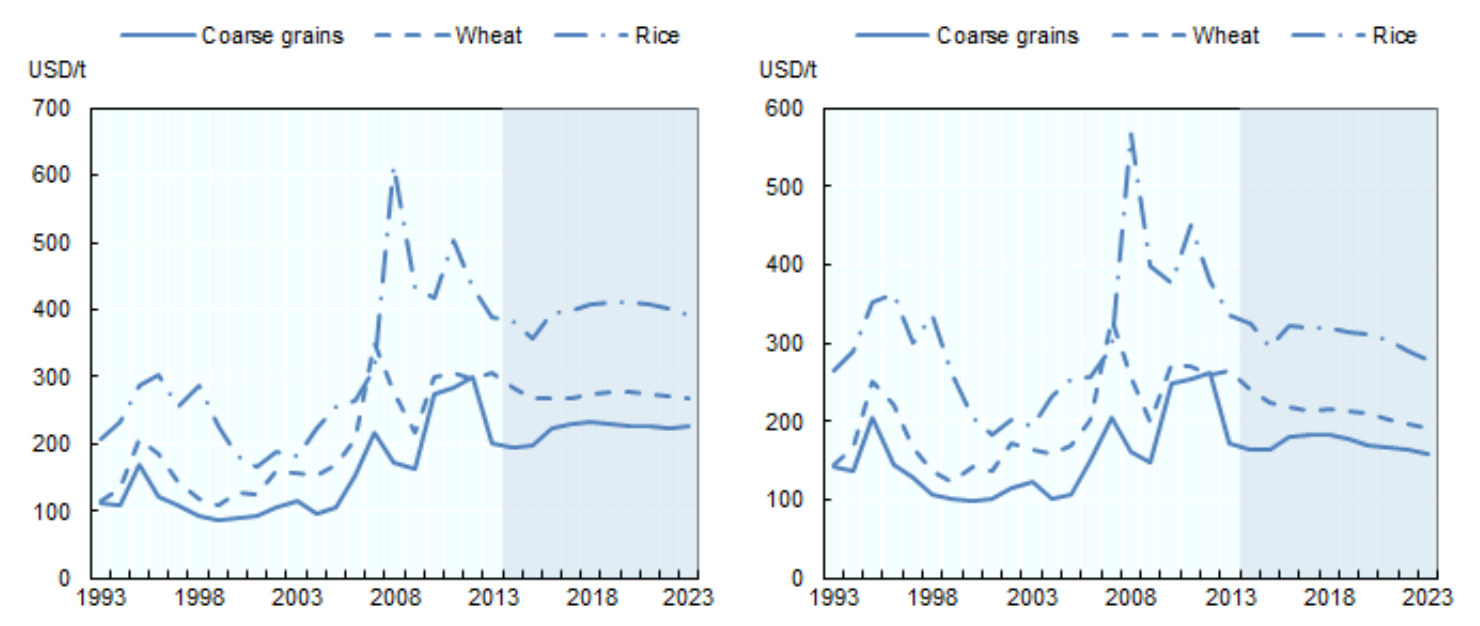

Source: Authors' own. 


\subsection{Why have prices fallen?}

After several years of a commodities super-cycle in which agricultural prices were strongly correlated with the prices of other seemingly unrelated commodities - posited to be due to the increased financialization of the commodities sector as a whole ${ }^{12}$ - there is evidence that food prices are increasingly responsive to fundamental factors. ${ }^{13}$ Early in 2014 cereal prices rose as a result of geopolitical tensions in the Black Sea region between Russia and Ukraine, but conditions improved after the first quarter. ${ }^{14}$ The subsequent fall in prices reflected both significant stock levels as a result of bumper harvests over the previous few seasons and the absence of any major climatic shocks. El Niño conditions originally forecast for 2014, which were expected to have had a negative impact on some major producers' harvests, did not begin to materialise (initially weakly) until the second quarter of $2015 .{ }^{15}$

Rice prices increased in mid-2014 largely as a result of the Thai government's decision to temporarily stop selling its public reserves, but global production through the year was strong, and prices fell again in the second half of the year. ${ }^{16}$ The temporary rally in wheat, maize and soybean prices towards the end of 2014 was largely the result of concerns over how newly planted crops in several major producing countries might have been affected by weather disruptions. However, prospects had improved by early 2015 and prices were again falling. ${ }^{17}$

The overall prospects for the 2014/15 season were good for all staple crops with global stock levels and stock-to-use ratios both forecast to improve further on the already comfortable levels of the previous year (Figure 7). Such stocks provide a buffer for when production volumes fall and help to reduce the prospect of any near-term price volatility.

\section{Figure 7: Improving stock levels and stock-to-use ratios for staple crops provide a buffer against future shocks}

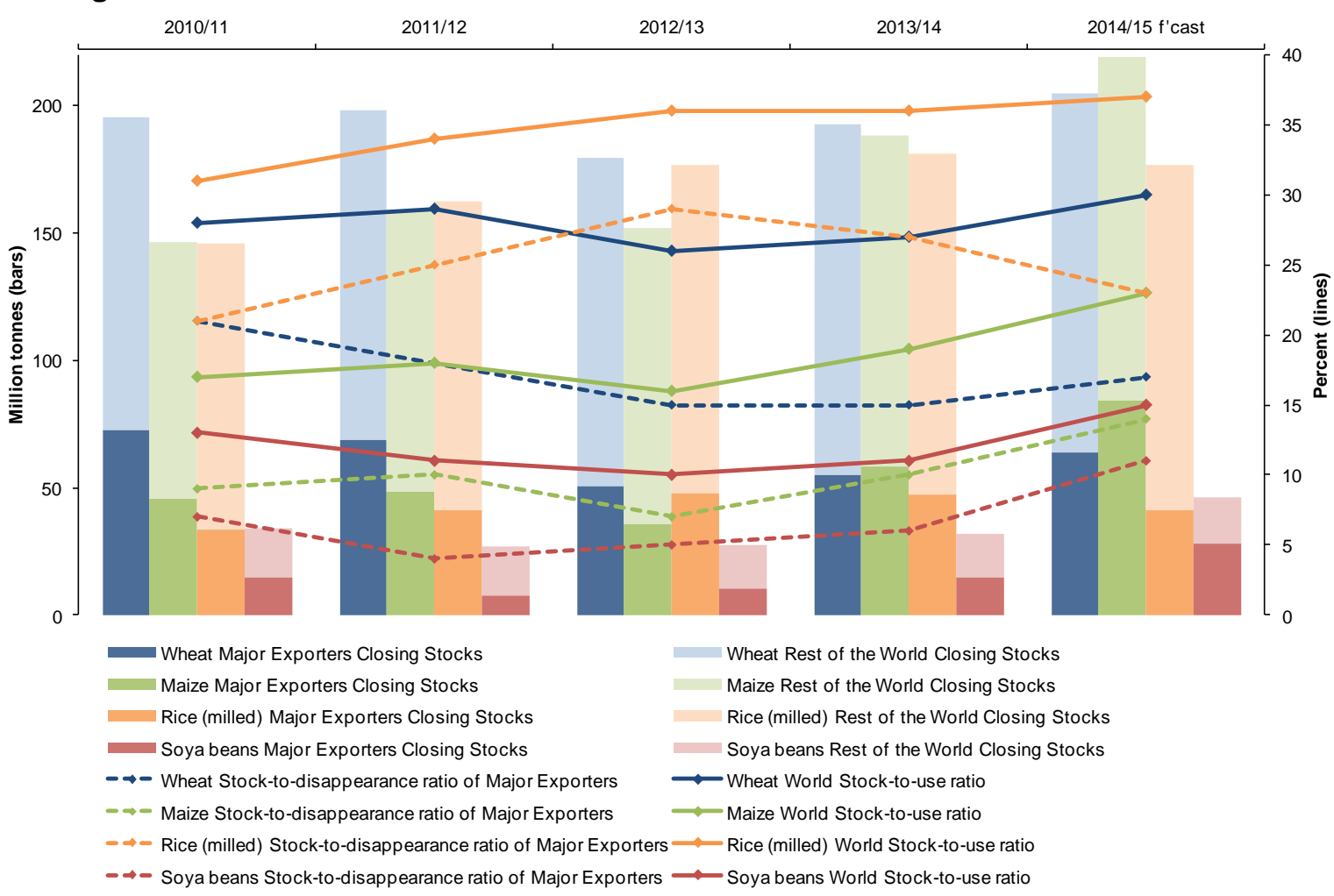

Source: AMIS, www.amis-outlook.org/index.php?id=40187 


\subsection{Policy developments}

There were several domestic policies and trade measures implemented in major agricultural markets that will have a bearing on global market dynamics (for example, in July 2014 and September 2014 the EU introduced and then doubled import duties on maize, rye and sorghum).${ }^{18}$ However, the impacts of two significant policy developments were not fully realised during the year. The first is the new Common Agricultural Policy of the EU for 201420. It began to enter into force at the beginning of 2014, but wasn't fully implemented until the beginning of 2015. Among the changes being made is a dismantling of all existing restrictions on production volumes. The second is the new US Agricultural Act of 2014, which will remain in force until 2018. This makes major changes in commodity programmes, bringing to an end payments to producers based purely on their historical production volumes. ${ }^{19}$

The dramatically lower oil price, as well as reducing the input costs of many agricultural products, is now having a negative impact on the economic viability of many biofuels (excluding those produced from sugar cane and palm oil). This may serve to reduce biofuel demand resulting in increased availability of the crops for food rather than fuel stocks. However in the US, renewable fuel mandates remain in place, so there is no sign of a reduction in biofuel production or demand for maize as a feedstock. ${ }^{20}$ 


\section{NATIONAL FOOD PRICES}

Global and local food price movements in 2014 exhibited more similarities than in recent years and local prices were generally less volatile than they have been of late.

\subsection{Bangladesh}

According to GIEWS price data (accessed 28 January 2015), the average retail price of coarse rice in Dhaka was about Tk34 per kg, and slightly lower in December 2014 than in January 2014. However, the average price in 2014 was about 5 per cent above the average in 2013. There was limited price fluctuation during the year (the coefficient of variation in the retail price of coarse rice in Dhaka over 2014 was 0.01 ). Average retail wheat flour prices in Dhaka were about Tk32 per kg, and declined by almost 8 per cent between January and December 2014. The average wheat flour price declined by about 2.5 per cent compared with the 2013 average. Average prices of palm oil (the main cooking oil, which is imported) fluctuated over the year, increasing to Tk84/itre in the month of Ramadan (July); the price fell back to Tk74/litre by October, slightly below the price in the same period in 2013. The price of lentils, a key non-animal source of protein, was Tk83/kg in October, marginally below the October 2013 level. Overall annual food price inflation was running at about 6-8 per cent over the year (WFP 2013, 2014d, 2014e).

Rice production was estimated at 34.35 million m.t. for the year 2013/14 (WFP 2014e), about 0.5 million m.t. higher than the previous year.

Average agricultural daily wage rates increased on average by 3-8 per cent; in the first half of 2014 that resulted in a decline in the terms of trade for agricultural day labourers by 7-15 per cent compared to the first half of 2013, whereas in July-August the terms of trade improved compared to the same period in 2013 (WFP 2014e). The cost of a minimum food basket, as measured by WFP, was 22 per cent higher in the third quarter of 2014 compared with the baseline (a moving average of the same quarter over the previous five years) (WFP 2014c), indicating that over the longer term prices of key food commodities are continuing to increase.

This picture of relatively little change during 2014 is to some extent indicative of the national situation in the years since the 2008 food price crisis. Although there have been major price fluctuations during that time, major indicators of food security and nutritional status have not changed much. The prevalence of undernourishment has remained close to 17 per cent in the last few years (approximately 26 million people) (FAO Food Security indicators 2014, ${ }^{21}$ ); stunting rates for children under the age of five remain very high at about 41 per cent (UNICEF, WHO and World Bank 2014), and prevalence of anaemia among women of reproductive age is even higher, at 44 per cent (IFPRI 2014a). Taking a longer perspective, there have been substantial improvements in food security and nutritional status since the 1990s, but the data suggest a slowdown in the rate of improvement in recent years, which may in part be attributable to higher food prices.

The qualitative interviews in the three study sites indicate that most food prices increased in 2014. As with previous years, prices in Dhaka are influenced by a variety of factors, including the impact of ongoing hartals, ${ }^{22}$ government taxes, increased costs of fertilisers and seeds, the influence of merchants, the added costs of importing from India, and so on; whereas prices in Khulna and Naogaon are relatively more influenced by local agricultural production conditions. However, wholesalers in the latter locations also influence prices by purchasing rice, fish and other commodities for sale elsewhere. 


\subsection{Bolivia}

Overall, food prices declined in Bolivia during 2014, although there were significant variations in price movements between different food commodities. Wholesale wheat prices remained relatively stable during the year; domestic production of wheat only meets about 35 per cent of consumption needs (GIEWS 2014a), the remainder being imported. The price of imported wheat flour fell considerably (by about 30 per cent) over the year (GIEWS price data ${ }^{23}$ ), and, combined with a good outlook for the wheat harvests, this resulted in significantly reduced consumer prices for wheat flour.

Rice prices fluctuated to a small extent: the rice harvest was relatively low due to heavy rainfall during the planting period (GIEWS 2014a).

Wholesale maize prices fell considerably over the year (by more than 30 per cent in Cochabamba and Santa Cruz, and by 20 per cent in La Paz (GIEWS price data)), partly due to a good harvest (approx. 1.1 million m.t.) (GIEWS 2014a) following on from good harvests in the previous two years.

Despite these generally declining trends in wholesale prices, year-on-year food inflation in the third quarter of 2014 was about 8.5 per cent (WFP 2014a), and the cost of a minimum food basket was 24 per cent higher compared with the baseline (WFP 2014c).

An examination of longer-term trends since the 2008 food price crisis suggests some improvement in food security indicators and nutritional status. The prevalence of undernourishment fell from 28 per cent (2.8 million people) in 2008-10 to 19.5 per cent in 2012-14 (2.1 million people) (FAO Food Security Indicators 2014, see footnote 21). Prevalence of stunting among children under the age of three fell from 26.4 per cent in 2008 to 18.5 per cent in 2012 (FAO 2014). Data on prevalence of anaemia among women of reproductive age remain relatively high, at 33 per cent (IFPRI 2014b). FAO (2014) discusses the range of pro-poor and food security policies, including smallholder agricultural programmes, social protection, and legal and constitutional developments to provide a 'Right to Food', which have contributed to the observed improvements.

\subsection{Burkina Faso}

According to GIEWS price data, overall, prices declined in Burkina Faso during 2014, although there were some seasonal and regional fluctuations. Food availability generally appears to be adequate, partly due to good harvests in the previous two years (GIEWS $2015 \mathrm{a}^{24}$ ). Wholesale prices of sorghum and millet in Ouagadougou remained relatively stable throughout the year. The wholesale price of imported rice (mostly consumed in urban areas) in Ouagadougou was stable for much of the year, falling in May-October but going back to its earlier levels (c.400CFA francs $/ \mathrm{kg}$ ) at year-end: this trend is in line with movements in the international price of rice (WFP 2014a, b and c).

Food prices in Burkina Faso are generally on a downward trend. The year-on-year inflation rate in the third quarter of 2014 fell by 6.2 per cent (WFP 2014c), and in the same quarter the cost of a minimum food basket was 3 per cent below the baseline (WFP 2014c).

The political upheaval in Burkina Faso in late October/early November, in which former President Compaore was forced from office, does not appear to have been directly linked with, nor to have any significant impact on, trends in food prices. However, other indicators reflect continuing high levels of poverty and food insecurity, with a poverty headcount rate of 
about 46 per cent (World Bank data ${ }^{25}$ ), and prevalence of undernourishment of almost 21 per cent (3.5 million people) (FAO Food Security Indicators ${ }^{26}$ ). The latter figure has slightly reduced from about 24 per cent in 2008, but over a longer time period there has been no consistent downward trend. Stunting rates among children under the age of five remain high, at 33 per cent (UNICEF et al. 2014), and prevalence of anaemia among women of reproductive age is very high at 50 per cent (IFPRI 2014c).

\subsection{Ethiopia}

Cereal production in the main 'meher' harvest was estimated at about 20 million m.t. (GIEWS $\left.2015 b^{27}\right)$. This is generally regarded as a good harvest, although yields were reduced in some areas due to low and erratic rainfall. The small 'belg' harvest earlier in the year was also generally good. Prices of main cereal food crops showed quite different trends. The wholesale price of teff was fairly stable throughout the year (average price Ethiopian Birr $12.15 / \mathrm{kg}$ ). The wholesale price of maize varied in different parts of the country, being lower in December 2014 in most markets compared with December 2013, but 8 per cent higher in Addis Ababa due to strong local demand (GIEWS 2015b ${ }^{28}$ ). Wholesale wheat prices increased quite significantly in many parts of the country: in Addis Ababa they were 26 per cent higher in December 2014 compared to January 2014. The WFP (2014g) notes that wheat import parity prices were about 43 per cent below local wholesale prices in October 2014: production has not kept up with growing demand in recent years, but, unlike in previous years, the Ethiopian government had not imported wheat or subsidised the local price.

The food CPI increased by 4.8 per cent in the third quarter compared with the same period in 2013 (WFP 2014h), while the overall CPI increased by 6.7 per cent, heavily influenced by increases in fuel costs of about 10 per cent. The cost of the food basket increased by 4 per cent in the third quarter compared to the second quarter, and by 38 per cent compared with the baseline (WFP 2014h). Despite relatively good production, an estimated 3.2 million people required relief food assistance in the second half of 2014 (GIEWS 2015b ${ }^{29}$ ).

Longer-term trends in food security and nutritional status in Ethiopia are positive, but from a very poor base, so rates remain high. Stunting rates among children under the age of five are 44 per cent (UNICEF et al. 2014), but this compares to a rate of 57 per cent in 2000.

Prevalence of undernourishment is currently 35 per cent, compared to about 42 per cent in 2007-9, and above 70 per cent in the 1990s (FAO Food Security Indicators). Prevalence of anaemia among women of reproductive age appears to be low at 19 per cent (IFPRI 2014d). Despite these positive trends, 33 million people in Ethiopia are still classed as undernourished (FAO Food Security Indicators). Ethiopia does have a very large Productive Safety Net Programme, which provides support to a significant proportion of the foodinsecure population.

The qualitative interviews generally confirm the national price trends. Most respondents, particularly in the rural site, stated that maize prices had fallen, mainly due to a good harvest, which encouraged farmers to release stored maize from the previous harvest onto the market. Conversely, wheat prices rose, as also shown in the national data; this was attributed partly to increased urban demand for wheat bread. Teff prices were stable or declined slightly, partly due to improved harvests, substitution of consumption by different cereals, and government intervention to control export of teff. 


\subsection{Guatemala}

According to GIEWS price data, prices of key food commodities increased during 2014, to differing degrees. Wholesale black bean prices increased by about 15 per cent both nationally and in Guatemala City between January and December 2014, although national average retail prices increased by about 12 per cent. National average white maize prices increased by about 16 per cent over the same period. National average retail prices of bread and maize tortillas increased by about 6 per cent and 10 per cent respectively. National average retail prices of rice remained relatively stable during the year.

In the third quarter of 2014 maize tortilla prices were 8 per cent higher than the same quarter in 2013 , and the overall cost of the food basket was 26 per cent above the baseline (WFP 2014c).

Drought-affected parts of Guatemala in September 2014, and sample surveys by WFP found 25 per cent of the population in affected areas (Oriente (eastern) and Occidente (western) regions) experiencing moderate or severe food insecurity (WFP 2014i).

Longer-term data on food security and nutritional status show minor improvements in some indicators over the last few years. However, stunting rates for children under the age of five remain very high, at 48 per cent (IFPRI 2014d). Prevalence of undernutrition is about 14 per cent, a slight reduction from recent years (FAO Food Security Indicators). Prevalence of anaemia among women of reproductive age is 26 per cent (IFPRI 2014e).

\subsection{Indonesia}

Retail rice prices increased by 6.5 per cent between January and December 2014 (GIEWS price data). Aggregate rice production during 2014 is estimated at about 70 million m.t., slightly below the 2013 level, and about 1.2 million m.t. of rice were expected to be imported (GIEWS 2015 $\mathrm{c}^{30}$ ). The increase in retail prices is likely to reflect marginally reduced production levels and increased imports (international rice prices fluctuated throughout the year).

Maize production is forecast to be about 18.6 million m.t., similar to 2013 levels; imports of maize were estimated at 2.7 million m.t. Wheat imports were expected to be similar to 2013 levels at about 7.4 million m.t. (GIEWS $2015 \mathrm{c}^{31}$ ). Since international maize and wheat prices declined for much of 2014 , lower prices of these commodities could be expected to partially offset increased rice prices. On average, over 2014 the cost of the food basket remained similar to 2013, but in the third quarter of 2014 it was still 20 per cent above the baseline (WFP 2014c).

Over the longer term, the food security status of Indonesia has improved: prevalence of undernourishment is now about 8 per cent, compared with more than 17 per cent in 2007-9 (FAO Food Security Indicators). Active food security policies, and broader reductions in poverty, appear to have contributed to this positive trend. Such policy measures include food price stabilisation, rice subsidies for the poor - providing about 17.5 million poor households with access to rice at one third of the market price -, measures to boost agricultural productivity, and legislative measures to make a food a human right (FAO 2014). However, stunting rates among children under the age of five are still high at 36 per cent (UNICEF et al. 2014). Prevalence of anaemia among women of reproductive age is quite low, at 23 per cent (IFPRI 2014g). 
The qualitative interviews generally support the national-level data: most respondents refer to some increase in rice prices during the year, primarily due to a reduced harvest compared to 2013. Prices of a number of basic commodities also increased during the Eid festivals, but otherwise prices of most commodities appear to have been relatively stable.

\subsection{Kenya}

According to GIEWS price data, prices of maize and beans fell considerably during 2014. Between January and December 2014, wholesale prices of maize fell by 26 per cent in Nairobi, 30 per cent in Eldoret (a surplus-producing area) and 40 per cent in Mombasa (the main port). However, this price trend was far from uniform: by June 2014 wholesale maize prices were about 23 per cent higher than in June 2013 in Eldoret and Mombasa, and about 10 per cent higher in Nairobi. This largely reflected an expected shortfall in maize production due to unfavourable rains and crop disease: aggregate cereal production was estimated at 3.5 million m.t., about 12 per cent below the five-year average (GIEWS 2015d $\mathrm{d}^{32}$ ). In response, the Kenyan government imported substantial quantities of maize ${ }^{33}$ from Tanzania and Uganda, leading to a substantial drop in wholesale prices: the wholesale maize price in Nairobi in December 2014 was about 30 per cent below the price in December 2013. Traders who purchased maize in anticipation of prices increasing due to the poor harvest have faced problems, as have surplus farmers who were holding on to stocks, as prices have fallen; however, low-income urban consumers benefit from lower maize prices.

Similar price trends were observed for beans, with prices tending to increase or remain stable in the first half of the year, and then declining in the second half, partly due to imports from the region. In the third quarter of 2014 overall year-on-year inflation was running at about 7.5 per cent, and the cost of the food basket was 18 per cent above the baseline of the previous five-year average (WFP 2014c).

Drought conditions in Kenya's pastoralist and marginal agricultural areas (mostly in northern Kenya) resulted in 1.5 million people requiring food assistance in October 2014, double the number needing assistance at the same time in 2013 (WFP 2014i).

Over the longer term, food security and nutrition indicators show signs of small improvement. Prevalence of undernourishment is 24 per cent, marginally below the level in 2007-09, but this still equates to over 10 million people being undernourished (FAO Food Security Indicators). Policy responses in terms of social protection programmes have until recently been rather piecemeal. Stunting rates among children under the age of five are 35 per cent, but there is no consistent trend in stunting rates over successive national surveys (UNICEF et al. 2014). Prevalence of anaemia among women of reproductive age is 25 per cent (IFPRI 2014f).

The qualitative interviews provide a more mixed picture of price trends during the year. In Lango Baya (the coastal site), the majority of respondents said that maize prices were lower in 2014 than 2013, but they attributed this more to an improved local harvest than to government imports: when local production is higher, households meet more of their consumption needs from their own production, thereby reducing market demand and forcing traders to reduce prices. Another factor was the security situation on the coast, which had reduced tourist numbers and therefore reduced demand for local produce in the towns. However, some respondents stated that prices of other commodities, including beans and wheat flour, had increased.

Respondents in Mukuru (the informal settlement in Nairobi) were more focused on prices increasing, and/or quantities reducing. Price of milk, sugar, fruits, sukuma wiki (kale), cooking 
fat, cooking fuel (charcoal/kerosene) and fish (omena) have increased. A number of respondents stated that they ate less and/or had reduced dietary quality as a result.

\subsection{Pakistan}

Staple prices were relatively stable for most of 2014, although in the first quarter of 2014 they were significantly higher than in the first quarter of 2013: for example, the retail price of wheat in Lahore in March 2014 was 30 per cent higher than in March 2013; the equivalent figure for Karachi was 8 per cent (GIEWS price data) Thereafter, retail prices of wheat and wheat flour began to decline, and this slight decline continued over the following few months. The retail price of wheat flour in Karachi in December 2014 was about 8 per cent lower than the previous December (GIEWS price data); the price in Lahore in December 2014 was almost the same as in December 2013.

The stabilisation and relative decline in wheat and wheat flour prices is primarily attributed to a good wheat harvest: national production was estimated at 25.3 million m.t., compared with 24 million m.t. in 2013 (WFP 2014f).

Rice prices remained almost unchanged during the year, following a fairly good harvest of 6.7 million m.t., slightly below the 2013 level (WFP 2014f).

Prices of other non-cereal food commodities fluctuated: prices of lentils and sugar increased, but prices of chickens and eggs decreased. Overall, in the third quarter of 2014, year-on-year food price inflation was 5.8 per cent, and overall inflation was 7.6 per cent; the cost of the food basket was 30 per cent higher than the baseline (WFP 2014c).

The terms of trade for unskilled labourers, measured against the price of wheat flour, generally improved over the year compared with the equivalent month in $2013,{ }^{34}$ and in November 2014 the terms of trade were 14 per cent higher than in November 2013. However, such increases would be smaller if the overall food CPI was used in the price comparisons.

Despite the relatively positive crop production figures and price trends, a considerable proportion of the population are food-insecure. Surveys in March-May 2014 found 12 districts/agencies in Pakistan were severely food-insecure (classified as IPC ${ }^{35} 4$ ), and a larger number of districts were classified as highly food-insecure (IPC 3).

In the longer term, there is little evidence of overall improvement in food security or nutritional status. Prevalence of undernourishment is unchanged over the last few years at 22 per cent, equating to almost 40 million people undernourished (FAO Food Security Indicators). Stunting rates among children under the age of five are 45 per cent, a marginal increase on levels from previous surveys (UNICEF et al. 2014). The prevalence rate of anaemia among women of reproductive age is very high at 51 per cent (IFPRI 2014h).

The qualitative interviews suggest a more varied picture of food price fluctuations. In the rural study area many respondents said that prices of wheat flour, rice, fish, meat, lentils and some vegetables had all increased; others said that wheat flour and rice prices had reduced, as had prices of some vegetables, such as potatoes; some of these fluctuations are seasonal in nature. In the longer term, prices are generally increasing and many respondents outlined their different ways of adapting, including eating cheaper vegetables (e.g. potatoes), collecting mustard leaves from the fields, getting food on credit from shopkeepers and repaying when income became available, reducing the number of times in the year and so on. 


\subsection{Vietnam}

According to GIEWS price data wholesale prices of rice fell by about 6 per cent between January and December 2014. This was primarily due to a good rice harvest: total rice production over 2014 was estimated at a record high of 44.5 million m.t., slightly above the 2013 level (GIEWS $2015 \mathrm{e}^{36}$ ). This high level of production came from a slightly reduced planted area, since the Vietnamese government pursued a policy of shifting some land under paddy to other crops, particularly maize and soybeans, partly to maintain rice prices to farmers (GIEWS 2015 ${ }^{37}$ ). Maize production is also quite significant: 2014 maize production was at a record level of 5.4 million m.t.

Although the overall trend was downwards, there was a spike in wholesale and retail rice prices in the middle of the year, until the autumn rice harvest started to exert downward pressure on prices. Retail prices increased 15 per cent between April and August (World Bank 2014). The main cause of this price rise was increased import demand from China, linked with reduced exports (related to political changes) from Thailand (World Bank 2014). The WFP Market Monitor (2014c) indicated that rice prices were 17 per cent higher in the third quarter compared to the same quarter in 2013, and that the cost of the food basket was 11 per cent above the baseline. By December 2014 prices had fallen back below the average price for 2013-14 (GIEWS price data).

Over the longer term, the food security and nutritional situation in Vietnam is improving. Prevalence of undernourishment is currently 13 per cent; this has declined from 17 per cent in 2007-9, but more substantially from levels of over 30 per cent in the late 1990s (FAO Food Security Indicators). However, 12 million people remain undernourished. Stunting rates among children under the age of five are 23 per cent, a significant decline from the 2008 level of 31 per cent (UNICEF et al. 2014). The prevalence of anaemia among women of reproductive age is low, at 14 per cent (IFPRI 2014i).

The qualitative interviews suggest that on average, there was relatively little change in food prices over the year, although some respondents referred to increased prices of rice, pork, eggs and sugar. The spike in prices referred to above was not mentioned by respondents. In the rural study site of An Giang, a high proportion of respondents grow rice, and most of their rice consumption is from own-production, so they are more likely to benefit from higher prices, at least if they are surplus farmers.

\subsection{Zambia}

According to GIEWS price data, prices of maize, breakfast maize meal, and roller maize meal, were slightly lower in December 2014 than in January 2014; however, respectively they were 20 per cent, 22 per cent and 14 per cent higher (in nominal terms) than price levels in January 2013, despite a record maize harvest of 3.35 million m.t. (GIEWS 2015f38). The low harvest in 2013, allied to the removal of maize and fuel subsidies and reduction in fertiliser subsidies during 2013, contributed to a rise in prices which continued until April-May 2014 and then fell, only starting to rise again late in the year. Year-on-year food price inflation in the first quarter of 2014 was 7 per cent (WFP 2014a) and 7.8 per cent in the second quarter (WFP 2014b). In the third quarter the cost of the food basket was 34 per cent above the baseline (WFP 2014c).

In December 2013 the Zambian government banned maize exports and released 50,000 m.t. of maize from the food security reserve to attempt to stabilise prices; ${ }^{39}$ however, prices continued to rise significantly until the harvest was brought in from May 2014 onwards. The 
national vulnerability assessment estimated that about 4 per cent of the rural population needed food assistance (GIEWS 2015 $f^{40}$ ).

Over the longer term, Zambia continues to display high levels of food insecurity and poor nutritional indicators, although there are some signs of moderately positive trends. The prevalence of undernourishment is very high at 48 per cent ( 7 million people); but this compares to 53 per cent in 2007-9, which was the peak of a long period of increasing undernourishment rates (in the mid-1990s the rate was about 33 per cent) (FAO Food Security Indicators). The stunting rate for children under the age of five is 46 per cent, ${ }^{41}$ still very high but a reduction from the 1999 level of 58 per cent (UNICEF et al. 2014). The prevalence of anaemia among women of reproductive age is 29 per cent (IFPRI 2014j). 


\section{SUMMARY}

Food price movements in the ten countries during 2014 generally displayed lower levels of volatility than in recent years, but there continue to be often quite marked seasonal changes, largely linked with the level of national food availability. The generally downward trend in international cereal prices was not uniformly mirrored in each of the countries, although some countries, e.g. Bolivia, Burkina Faso and Vietnam, did mostly experience falling prices. The cumulative effect of lower international grain prices on the food basket is evident in improved quarterly changes in most countries (Table 2), but its effect on the food basket in relation to the baseline is still severe in all countries except Vietnam and Bangladesh (Table 3). In all countries for which data were available annual food inflation and general inflation continue at levels (commonly between 6-8 per cent) that create hardship for market-dependent lowincome households (see Figure 8 ). In all countries, the cost of the minimum food basket continues to be well above the five-year average, which reinforces the view that the struggle to cope with high food prices is a long-term reality, which has not diminished just because food price increases have recently been less dramatic. The need for effective action to enhance resilience and reduce the negative effects of food price changes is as pressing as ever.

Annual food price changes have to be seen in the broader context of trends in food security and nutritional status. There is considerable variation in these trends across countries; generally, countries with active policies in relation to agriculture/food security, social protection and nutrition, have made the most gains in recent years: these countries include Bolivia, Ethiopia, Indonesia and Vietnam. Other countries such as Bangladesh have seen significant improvements in some indicators over a longer time frame, but less so in recent years. The generally substantial increases in food prices over the period since 2008 have had a negative impact on food security and nutrition for many households, particularly where the policy response has been inadequate.

Table 2: Cumulative impact of main staple food price changes on cost of the food basket, relative to previous quarter

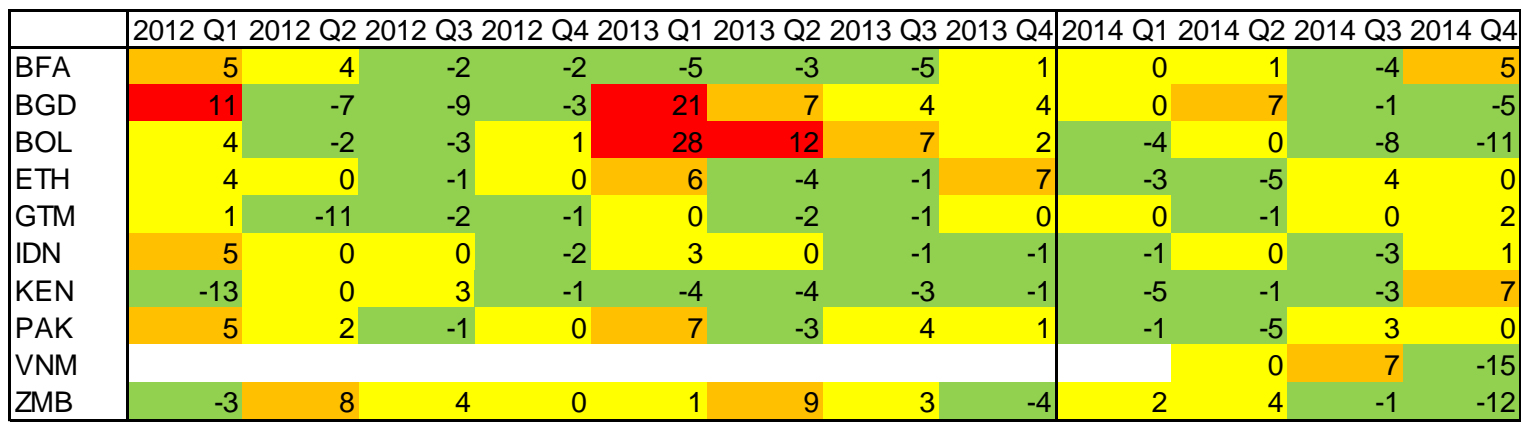

\begin{tabular}{|lllll|}
\hline No data & Low $(<0 \%)$ & Moderate $(0-5 \%)$ & High $(5-10 \%)$ & Severe $(>10 \%)$ \\
\hline
\end{tabular}

Note 1: Tables 2 and 3 assume that the caloric contribution of the main staples monitored are proxies of the relative importance of the food items in the food basket. Source: WFP (n.d.).

Note 2: Changes in Vietnam consumer price index of staple food in $2012-2014$ relative to previous quarter. Source: Vietnam General Statistics Office 2015

\begin{tabular}{|l|l|l|l|l|l|l|l|l|l|l|l|l|}
\hline Year & 2012 & \multicolumn{1}{|l|}{2013} & 2014 & \\
\hline Quarter & Q1 & Q2 & Q3 & Q4 & Q1 & Q2 & Q3 & Q4 & Q1 & Q2 & Q3 & Q4 \\
\hline$\%$ & -1 & -1 & -1 & 0 & 0 & -1 & 0 & 1 & 1 & 0 & 0 & 0 \\
\hline
\end{tabular}


Table 3: Cumulative impact of main staple food price changes on cost of the food basket, relative to baseline

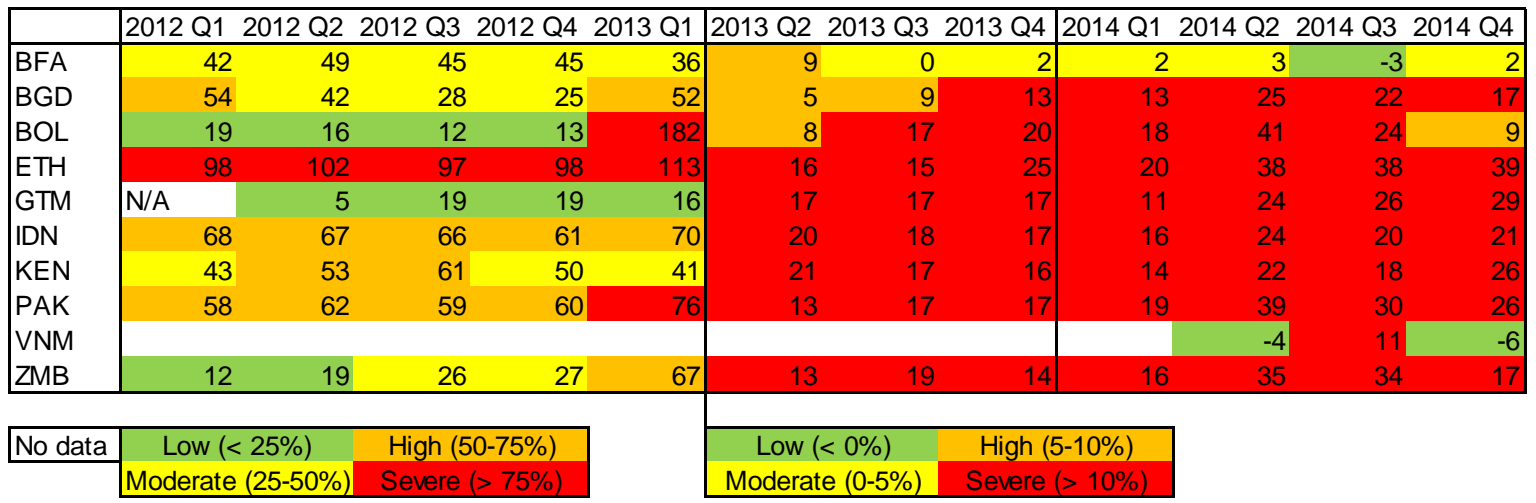

Note 1: Qualitative assessment of category thresholds reclassified in 2013 Q1, prior thresholds have been adjusted for consistency.

Note 2: To take into account global structural changes resulting in volatile food prices, the baseline period changed as of 2013 Q2 from the 2003-07 five-year average to a moving period covering the previous five years of the same quarter (e.g. 2008 Q2 to 2012 Q2). However, available data for the baseline period does not always cover the whole five years. Pre-2013 Q2 values should not, therefore, be compared with those for 2013 Q2 onwards. Source: WFP (n.d.).

Figure 8: Food and general consumer price inflation 2012-2014

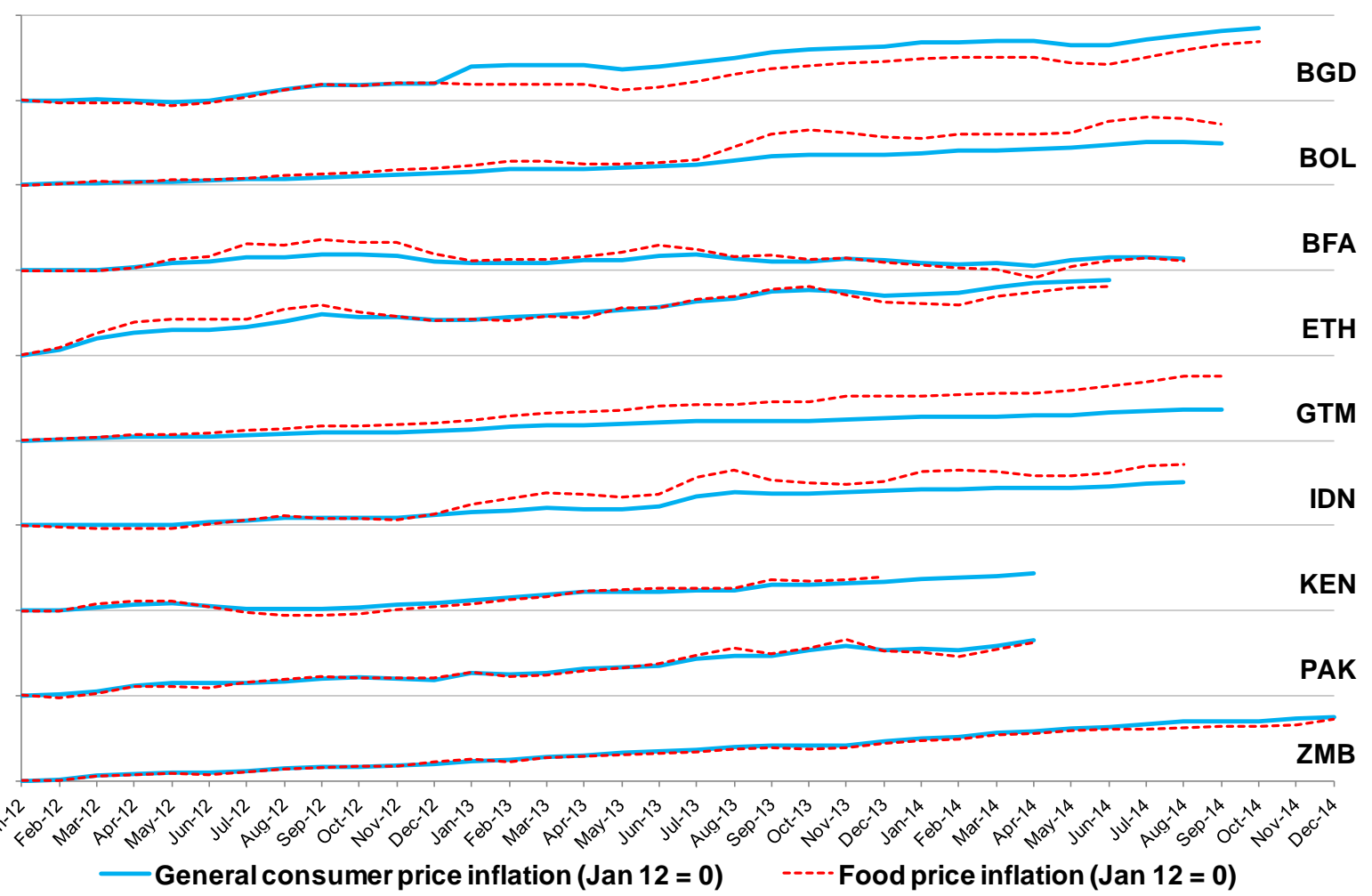

Note: the range for each country is $0-30$ per cent. No data available for Vietnam

Source: http://laborsta.ilo.org/sti/EN/SUB/CPI TCPI IN.XIs 


\section{CONCLUSIONS}

In the first section of this report we demonstrated that people are alert to the changes that are going on in their food cultures. Food, far from being a simple commodity or nutritive fuel, has profound health, social and cultural significance in these communities. Varied in quality and safety, the foods people are eating provide for some and withhold from others values such as nourishment, health, status, culture, taste and novelty. The class, gender and generational patterns of food-related stress are remarkably consistent across the 23 sites; the levels of government responsibility for protection and information are more variable.

Although we are now accustomed to the idea that overweight may be correlated with poverty in the developed world, we are less au fait with this form of malnutrition in developing countries; the stereotypical image of the underweight person unable to get enough calories lingers in the popular imagination as the manifestation of poor nourishment. As previous rounds of this research have demonstrated, many people do still struggle to get enough to eat, often because higher prices of foods have left them 'squeezed' as their earnings have not adjusted, other costs of living have risen or the adjustment has left them worse-off in terms of time for care, safety at work or quality of life (Hossain et al. 2013). The changing composition of diets, even in low- and middle-income countries facing severe problems of hunger means that the notion of 'enough' in relation to food needs rethinking. Obtaining enough calories is not sufficient; food must also provide nourishment in terms of macro- and micro-nutrients of reasonable quality and diversity. Antithetically, 'too much' is also a danger in terms of salts, sugars, empty calories, strange, possibly toxic chemicals and bacteria. So in the research sites, we meet people who face times when they struggle to secure enough basic food to stave off physiological hunger - usually when food prices are high or there is no work to be had because it is the wrong season, or industries are not hiring any more, or there are too many people looking for work. But we also see here that for many people, very likely the growing majority, the struggle is more often about being able to eat diverse, nutritionallybalanced meals, because they cannot afford to eat nutrient-rich foods, or because the food that is affordable and considered 'safe' is packed with fats, sugars and additives. Parents worry about this in particular, as we have seen.

So while the problem of food and nutrition security in these communities remains a problem of food access, it is also one of inadequate utilisation due to the 'wrong' kinds of foods being accessible for proper nourishment. People eat what they can, what they calculate to be of the greatest value, as long as it is not disgusting or taboo within their society's cuisine (Rozin 2005,2007 ). This may appear to be a trivial point or a truism, but in fact it points squarely to changes in food supply which are at the heart of contemporary criticisms of the world food system (Clapp 2011). When we talk of changing food habits it is clear that what has changed in the world is not people's biological and nutritional needs, but what is being supplied to meet them, and the social and cultural constructions being placed on them.

The supply of food to people on low incomes, in both developed and developing countries, is increasingly of items which have travelled a considerable distance to the plate, produced, processed, packaged, distributed, marketed and advertised along their journey (Patel 2012). That distance (Clapp 2011) or 'delocalisation' (Pelto and Pelto 1983) is not only physical, but also mental or conceptual. As we have seen, people's fears about the food they eat are related as much to what they (think they) know of how the food they eat is produced and prepared as it is to what they do not know (and fear) about those processes. 


\subsection{The link to food price volatility}

How are these changing food habits related to the recent period of food price volatility chiefly, but not only rapid price rises - since 2007? As understanding how people are living through this period is the core objective of our research, we always relate our research findings back to this context, attempting to assess the extent to which rapid food price changes are part of the story. With respect to changing food habits in these settings, we detect three ways in which the food price situation may be related to the way people eat now.

First, higher food prices and the demand for more convenience foods are connected via changing working patterns and the impact of this on time and energy available for home cooking. Particularly notable is that in most of these communities, adult women are more likely to work outside the home than in the past, and so have less time to produce, process and prepare food. This shift is frequently attributed to higher costs of living, in particular of food (which comprises a high proportion of spending in these households). This means that home cooking is by no means a thing of the past - it still works out cheapest for most family members to eat at home - but it is more hybrid - some dishes are bought in their entirety, sauce and spices come in quick-cook highly processed forms, and quicker, simpler staple dishes tend to be cooked rather than more complex or effortful seasonal or local specialities. Urban men have always eaten on the go, but we found that rural men are also now more likely to be eating out than in the past, as in these communities many have shifted from working on their own land to working as wage labourers or otherwise away from home, usually without access to kitchens or cookware. Again, in some sites, changing work patterns and new occupations, particularly off-farm occupations, have been linked to the growing unreliability or low returns from agriculture, coupled with the rising need for cash incomes to pay for food and the other necessities of life. And men, who are often more mobile than women, may be more tempted by the growing range of food available outside, particularly if they do hard physical labour (as most men in these research sites do).

Second, rising fear about food safety appears to relate to the fact that the profits from selling adulterated or prohibited food or food prepared without regard to (costlier) safety standards can be higher when food prices rise. This is partly because people are anxious to maintain their eating standards when prices rise, and will substitute items about which they may be uncertain in an effort to do so. In Northern Province in Zambia, for instance, people who can no longer afford kapenta or sardines have shifted to dagaa, even though they believe this small fish is processed unsafely and bad for their health in the longer term. People in Java said they were tricked into buying an unknown (cheaper) variety of rice when they thought they were buying the favoured local variety, thought to be safer and more nutritious. Irregularity and criminality in the supply of bad food is made worse by the rising demand for affordable street foods and for cheap processed ingredients; this has expanded a market for foods about which information is either hard to come by or hard to make sense of. People whose food budgets are squeezed, regularly trade-off the safety of knowledge about what they put in their mouths in order to save on cost. People on lower incomes will be most exposed to bad and fake foods.

The third connection is a correlation, not a causal link: both phenomena - volatile and rising food prices and changing food habits - are aspects of the same broad process of the globalisation of the food system, which involves an increase in the industrialisation of food production processes, of the integration of world food trade, and of the financialization of food commodities (Clapp 2009, 2011; Ploeg 2010; Patel 2012). The effects of these connected processes on the everyday patterns of life include a sharp increase in the commodification of people's relationships to food in recent years, most notably since the food price rises of 2007. Several of our respondents date specific changes in local food cultures - new markets in 
cooked food, for instance - to precisely this period of time (although they link it to local, not global, factors). Spending a higher relative share of family income on food has meant cash incomes have become more vital for basic survival: a subsistence-oriented livelihood is no longer conceivable. Those who continue to produce food must do so to sell it into lengthy marketing chains, not to eat it themselves. Most people buy more of their food than they did a decade ago. Their relationship to food has become more of a relationship to a market commodity, and less to the essential stuff of life, a substance to which they have a fundamental human right.

The commodification of people's relationships to food is characterised by a new and growing distance from most of what they eat. Although novelty comes with a great many pleasures, the distance between everyday eating and everyday eaters appears to have a significant impact on anxieties about food. Commodification is also accompanied, it seems, by a homogenisation of basic foods: while the vast and growing number of packaged and commercially processed foods available on the market gives the illusion of wider consumer choice, in fact it appears that diversity in staple foods, mainly grains, is being lost with a narrowing towards a smaller range of monocropped commodities like maize, wheat and white rice. A similar process is reported with regard to protein-rich foods (growing access to factoryfarmed chicken, in particular), and oils (commercial vegetable oil preparations replacing traditional pressed oils from nuts and seeds). Seasonal and regional specialities, knowledge about food production and processing, customary recipes and cooking practices, and no doubt cultural meaning, are all being lost as a result. While it is not helpful to romanticise traditional diets - particularly in places that have been prone to food crises and famines and now face the uncertainties of climate change - it is very important to acknowledge the cultural, social and nutritional diversity losses incurred with these changing food cultures.

\subsection{Control and knowledge as food cultures change}

Changes in food habits mean people are finding new ways to enjoy food and new foods to enjoy, often with greater convenience and ease. New markets for purchased and prepared foods are rapidly opening up across these locations, and there is much to enjoy in this new eating landscape. For the consumer, there are undeniably potential benefits from the integration of world food trade: cheaper staples, more stable food supply, wider influences on diets. But the loss of control this brings with it has actual (and not just potential) detrimental impacts on human wellbeing. These are partly because people lack the knowledge of how new foods affect their health and nutrition that they had accrued over generations and longer with respect to their customary cuisines. That is not to say that customary cuisines were isolated, immutable and unchanging (Laudan 2013), or indeed universally health-giving and nutritious; but they nevertheless developed over centuries or millennia, and societies learned how different foods affected their health and wellbeing over time and incorporated those lessons within their food cultures. In that process, customary cuisines were not (till the second half of the twentieth century) subjected to sudden and sustained marketing campaigns whose aim was precisely to displace those food traditions.

We have shown that the lack of embedded cultural knowledge about new foods and new ways of eating is becoming evident in these developing countries. It is already self-evident in the media food scares that periodically erupt in the developed countries, and even more so in the epidemic of obesity in the West that is fast infecting the developing world. Knowing what you are putting in your mouth - how it was produced, processed and what went into its preparation - appears to be an increasingly important pre-condition for basic human health and wellbeing (for a classic statement of the problem, see Pollan 2007). 
Wellbeing is also negatively affected because it is difficult, if not impossible, for people on low and precarious incomes to resist the incursion of highly marketed low-cost packaged and processed foods that offer good value along many dimensions. The adverse effects of the power of advertising over small children is an established fact; in developing countries where adults may not have the formal education that could empower them to counter such messages, children are at great risk of being seduced into chronically unhealthy eating habits. Well-intended efforts to fortify processed snack foods and drinks to add micro-nutrients to undernourished children's diets may thus risk winning the battle by laying the groundwork to lose the war. ${ }^{42}$

From what we can see in most of our 23 research sites, the net results of loss of control (or 'sovereignty', as the food sovereignty movement correctly puts it) over food are likely to be an inability to gauge the health and nutritional effects of what people are eating, and fear and anxiety about the bodily and social changes resulting from food culture changes that people feel powerless to moderate, let alone resist. 


\section{RECOMMENDATIONS}

Recommendations arising from these findings centre on the insight that loss of control over what people eat is an important aspect of the illbeing they face with fast-changing food cultures. A principle of food and nutrition security policies in developing countries should be to restore or shore up that control; any intervention with the potential to reduce or weaken people's control over their food will disempower them further. People cannot be secure regarding the food they eat, nor can they achieve good nutrition levels if they fear they are unable to protect their families from food that may be unsafe or of no nutritional benefit.

While current generations retain faith in and knowledge of customary cuisines and food cultures, there is at least knowledge of the alternatives to processed and packaged foods, and of safety in food preparation. But this knowledge is likely to be lost as younger people reject traditional foods and cooking practices, and rely more on food eaten out or bought in. This knowledge - which is ingrained cultural knowledge, entirely different from 'nutrition information' or messaging - appears to be at some risk of being lost in large part to coming generations.

An obvious recommendation for national and local governments is to treat food culture as they do tangible culture - as precious, worth documenting, protecting and investing in. This means not only haute cuisine, but also the local specialities, dishes and ingredients that have comprised everyday eating. Young people are more likely to learn about their customary cuisines if they recognise these as valued and special aspects of their own culture. Ministries of trade and food may be better equipped to resist the homogenising effects of the global food trade if traditional grains and cuisines enjoy cultural status. Tourism can only benefit from the protection of distinctive cultural forms, of which local foods are often an important and neglected part.

But this risks turning traditional foods into museum artefacts if people cannot make genuinely informed choices based on true assessments of the health and social costs and benefits - the real value - of the new foods increasingly available to them. People need information to be able to make their food choices properly, and this information cannot come solely from private sector advertising.

As several parents pointed out to us, certain newly available foods can be literally addictive for small children, with lifelong effects on health. A second recommendation for national governments is therefore to review and reconsider their regulations on food and drink advertising, with specific emphasis on restricting advertising likely to appeal to children. This is easier said than done, as most of the growth in profits in the Big Food industry is now in developing countries (Stuckler and Nestle 2012). But this is where some of the new and emerging crises of food lie. They should also take strong action against marketing on the basis of purported health and nutrition benefits in processed and packaged foods $-\mathrm{a}$ widespread ploy which is now protected against to some extent in developed countries.

Related to this is that authorities involved in food and nutrition security should reconsider whether investments in fortified foods could be sending out confusing messages to adults trying to provide balanced nourishment to children. This may be true even if fortification programmes successfully address specific nutritional problems such as micronutrient deficiencies. While emergency or acute malnutrition situations should be excepted, and in contexts where monoculture farming has long depleted the nutritive aspects of common grains, fortification may be the only short-term answer; there can be no good long-term reasons to attempt to replace customary cuisines with processed foods, however successfully fortified. School and infant feeding programmes, for instance, should guard against the 
substitution of often expensive and imported foods for nutritionally-balanced meals based on local foods: in Bolivia, for instance, people complain of the effects of such supposedly 'good' foods on children's eating habits. The shift to homegrown school feeding is a good example of longer-term thinking in nutrition interventions that has the potential to increase local control over food and nutrition security.

With regard to food safety, returning local control is a broader issue at several levels. A key principle here is that these are public health issues, and the public needs to have trust in its system of regulation. And one way they can gain trust is through better knowledge of the food safety regime (assuming one is functional - this is not always the case). We see that in some of these communities trust is being gained through active efforts to tackle harmful food production or preparation processes. The mass media also plays a vital role in reporting on food safety violations, and in creating pressures on governments to act (although food safety scares are also excellent news stories, so the incentives to scare-monger can also be strong). In some countries, such as Bangladesh, active consumer groups such as the 'Stop Poisoning Us' campaign ${ }^{43}$ keep people informed, ensure food safety matters remain high on the public agenda and have successfully pushed for legal and programmatic reforms. From our work it is evident that low-income consumers have a number of local strategies for guarding against local foods deemed unsafe, including through the use of reputational pressures and 'brand' loyalty. If donors are keen to support food safety issues they could sensibly support investigative journalism and the popular communication of scientific studies on food safety, as well as spaces in which consumer safety groups can build their campaigns, from the local levels right up to the global. There is a strong and growing appetite for food that is delicious, without being disgusting or possibly dangerous. 


\section{NOTES}

${ }^{1}$ Raj Patel's Stuffed and Starved analyses how the global food system causes both hunger and obesity with the industrialisation and financialization of food production and distribution, led by multinational corporations (Patel 2012). Barry Popkin's summary explanation of the nutrition transition is: '[m]ajor dietary change [that] includes a large increase in the consumption of fat and added sugar in the diet, often a marked increase in animal food products contrasted with a fall in total cereal intake and fibre. In many ways this seems to be an inexorable shift to the higher fat Western diet, reflected in a large proportion of the population consuming over 30 per cent of energy from fat' (Popkin 2001: 871S) (emphasis added).

${ }^{2}$ On the psychology of food and eating see Rozin (2007).

${ }^{3}$ Changes in the reliance on enjera might reflect the extreme volatilities in the price of teff in the past. Similarly, we heard in previous years of research that Bolivian youth were rejecting quinoa in favour of processed imports, while adult women worried that it was less available than in the past. It may be significant that teff has recently been touted as 'the next superfood', after quinoa, as another proteinand nutrient-rich grain that can satisfy the demanding palates and plates of affluent diet-conscious Westerners (Provost and Jobson 2014).

${ }^{4}$ Legend has it that the potato was imported to Europe from North America by the sixteenth century explorer Sir Walter Raleigh; Chicken Tikka Masala originated in a Glaswegian Indian restaurant; and Goody recounts the origins of Worcestershire sauce in a fermented effort by a former British Governor of Bengal to recreate his favourite spicy Bengali dish (Goody 1997).

${ }^{5}$ Although typically instinctive and pre-cultural, disgust and food preference clearly also evolves into cultural forms. European preferences for strong-smelling aged dairy products have never made it into Chinese cuisine, for instance (Rozin 2002).

${ }^{6}$ The company website is a micro-history of globalisation in food in its own right, starting with the moving story of the widowed mother of three who, over 100 years ago, created the flagship product of this multinational which by 2015 , had 27,600 employees worldwide, sales in 26 countries and a growing range of seasonings and sauces www.ajinomoto.com/en/aboutus/?scid=av_ot_pc_comehead_aboutus (accessed 8 May 2015).

7 The Mezan Group is a Pakistani limited company that started as a textile mill in the 1950s and now produces four cooking fats, including one Banaspati which is 'manufactured through STATE OF THE ART of the refining process which keeps intact the NATURAL GOODNESS of palm oil' (The website stresses the health benefits of using Mezan oil in preference to others, and offers a Body Mass Index (BMI) calculator under the section entitled 'Balance Diet Balance Life'. Mezan Group website, www.mezangrp.com/mezan/products/mezan-banaspati/about/ (accessed 11 May 2015).

${ }^{8}$ Maggi refers here to bouillon or stock cubes used to season or give the flavour of meat to sauces, soups and stocks. The brand is 150 years old, and has been owned by Nestlé for the last 60 . There are at least nine national websites for Maggi products, and the brand puts considerable emphasis on using local knowledge in production processes and adapting to local tastes and preferences in its products. The brand page on the Nestlé parent website describes it as the 'Maggi brand - the flavour that fresh food loves, helping you make nutritious, delicious meals.'

www.nestle.com/brands/allbrands/maggi_culinary (accessed 11 May 2015). Since 2012, Maggi cubes sold in West and Central Africa have been fortified with iron, in addition to iodine (Nestlé 2015).

From our brief search of scientific journals, research on the health or nutrition effects of eating Maggi cubes on humans appears to be scarce or unintelligible, and none is listed on the brand's Wikipedia page. Nevertheless, a number of health and food bloggers have taken up the case; see, for instance, www.afronutritionfitness.com/2013/01/why-you-should-say-no-to-maggi-and.html (accessed 11 May 2015). However, Nestlé has also taken up the cause of lower salt intake in cooking, noting on the Nestlé Family website that 'Less salt in your food enhances good health' and that 'When you add MAGGI stock cubes to your cooking, it provides you with the right amount of salt needed for optimal 
flavour of the recipe so there is no need to add more salt to your cooking'. It is not made clear how Maggi knows what the 'right amount of salt' could be in your cooking. See www.nestle-

family.com/nutrition-for-all/english/less-salt-in-your-food-enhances-good-health_378706.aspx (accessed 11 May 2015).

${ }^{9}$ Royco Mchuzi Mix® is a seasoning produced for the Kenyan market by the multinational giant Unilever for almost three decades. The brand's website describes its benefits as including that it 'gives food a wonderful taste', 'Brings the family together', 'Increased confidence as a woman and a mother: Your family will love your cooking' and 'Satisfaction that my food expresses my best effort.' It includes a section on 'using less salt' but the page was not working when we visited it (www.unileveresa.com/our-brands/detail/Royco/348937/; accessed 10 June 2015).

${ }^{10}$ www.foodsecurityportal.org/policy-analysis-tools/excessive-food-price-variability-early-warningsystem.

${ }^{11}$ www.agri-outlook.org/.

12 www.peri.umass.edu/fileadmin/pdf/working_papers/working_papers_351-400/WP376.pdf.

${ }^{13}$ www.ft.com/cms/s/0/347bd65c-b207-11e4-8396-00144feab7de.html.

${ }^{14}$ www.worldbank.org/content/dam/Worldbank/document/Poverty per cent20documents/pov-FPW_Sept per cent202014_final-web.pdf.

${ }^{15}$ www.cpc.ncep.noaa.gov/products/analysis_monitoring/enso_advisory/ensodisc.pdf (9 April 2015 Version).

${ }^{16}$ www.worldbank.org/content/dam/Worldbank/document/Poverty per cent20documents/pov-FPW_Sept per cent202014_final-web.pdf.

17 www.amis-

outlook.org/fileadmin/user_upload/amis/docs/Market_monitor/AMIS_Market_Monitor_Issue_24.pdf; www.amisoutlook.org/fileadmin/user_upload/amis/docs/Market_monitor/AMIS_Market_Monitor_Issue_25.pdf.

18 www.amisoutlook.org/fileadmin/user_upload/amis/docs/Market_monitor/AMIS_Market_Monitor_Issue_22.pdf. See back issues of the AMIS Market Monitor for useful summaries of other policy measures, www.amis-outlook.org/amis-monitoring/en/.

${ }^{19}$ www.agri-outlook.org.

${ }^{20}$ www.odi.org/sites/odi.org.uk/files/odi-assets/publications-opinion-files/9520.pdf.

${ }^{21}$ www.fao.org/economic/ess/ess-fs/ess-fadata/en/\#.VMowSGisVVI.

22 Hartals are strikes linked to political protests, which have been called regularly in recent times as a result of ongoing disputes between the governing party and the main opposition party. Hartals often result in blockades and disruption of movement of goods, thereby adding to transport costs.

${ }^{23}$ Where GIEWS price data is referenced throughout the report, this refers to www.fao.org/giews/pricetool/.

${ }^{24}$ Figures correct as at 16 January 2014.

${ }^{25} \mathrm{http}: / /$ data.worldbank.org/country/burkina-faso.

${ }^{26}$ www.fao.org/economic/ess/ess-fs/en/.

${ }^{27}$ Figures correct as at 23 January 2015.

${ }^{28}$ Figures correct as at 23 January 2015.

${ }^{29}$ Figures correct as at 23 January 2015.

${ }^{30}$ Figures correct as at 10 September 2014.

${ }^{31}$ Figures correct as at 10 September 2014.

${ }^{32}$ Figures correct as at 13 November 2014. 
${ }^{33}$ Local press reported that 1.8 million 90kg bags would be imported between August and October 2014 (see agritrade.cta.int/Agriculture/Commodities/Cereals, $17^{\text {th }}$ November 2014), amounting to about 5 per cent of forecast production.

34 Terms of trade measured as the amount of wheat flour which could be purchased with a day's wage of an unskilled labourer, based on average wage rates in five major cities (WFP 2014j).

35 Integrated Food Security Phase Classification.

${ }^{36}$ Figures correct as at 29 September 2014.

${ }^{37}$ Figures correct as at 29 September 2014.

${ }^{38}$ Figures correct as at 4 November 2014.

${ }^{39}$ Lusaka Times, 21 December 2013 (see www.lusakatimes.com/2013/12/21/government-bans-maizeexport-offloads-50000-metric-tonnes-stabilise-mealie-meal-prices/: accessed 4 Feb 2015).

40 Figures correct as at 4 November 2014.

41 The most recent data, however, are for 2007.

42 Note that the United State's Food and Drug Administration discourages the addition of nutrients to snack foods because it may give a false impression of nutritional value (see Marion Nestle's 'Food Politics' blog, Nestle 2013). See also Monteiro, Gomes and Cannon (2010); Stuckler and Nestle (2012).

${ }^{43}$ www.facebook.com/pages/STOP-Poisoning-Us/687778964618933?fref=ts. 


\section{BIBLIOGRAPHY}

Ahmed, Raisuddin; Haggblade, Steven and Chowdhury, Tawfiq-e-Elahi (2000) Out of the Shadow of Famine: Evolving Food Markets and Food Policy in Bangladesh, Washington DC: International Food Policy Research Institute

Alexander, David (2000) 'The Geography of Italian Pasta', The Professional Geographer 52.3: 553-66

Atwood, D.A.; Jahangir, A.S.M.; Smith, Herbie and Kabir, Golam (2000) 'Food Aid in Bangladesh: From Relief to Development', in Raisuddin Ahmed, Steven Haggblade and Tawfiq-E-Elahi Chowdhury (eds), Out of the Shadow of Famine: Evolving Food Markets and Food Policy in Bangladesh, Washington DC: IFPRI

Clapp, Jennifer (2012) Hunger in the Balance: The New Politics of International Food Aid, Ithaca NY: Cornell University Press

Clapp, Jennifer (2011) Food, 1st ed., Cambridge: Polity

Clapp, Jennifer (2009) 'Food Price Volatility and Vulnerability in the Global South:

Considering the Global Economic Context', Third World Quarterly 30.6: 1183-96

Collingham, Lizzie (2012) Taste of War: World War Il and the Battle for Food, New York NY: Penguin

DeVault, Marjorie L. (1994) Feeding the Family: The Social Organization of Caring as Gendered Work, Chicago and London: University of Chicago Press

Drewnowski, Adam and Popkin, Barry M. (1997) 'The Nutrition Transition: New Trends in the Global Diet', Nutrition Reviews 55.2: 31-43

Food and Agriculture Organization (FAO) (2014) 'The State of Food Insecurity in the World (SOFI) 2014', FAO, www.fao.org/publications/sofi/2014/en/ (accessed 14 September 2015)

Fraser, Evan D.G. and Rimas, Andrew (2010) Empires of Food: Feast, Famine, and the Rise and Fall of Civilizations, Berkeley CA: Counterpoint

Freidberg, Susanne (2003) 'Editorial Not All Sweetness and Light: New Cultural Geographies of Food', Social \& Cultural Geography 4.1: 3-6

Global Information and Early Warning System (GIEWS) (2015a) 'GIEWS Country Brief: Burkina Faso', GIEWS, www.fao.org/giews/countrybrief/country.jsp?code=BFA (accessed 14 September 2015)

Global Information and Early Warning System (GIEWS) (2015b) 'GIEWS Country Brief: Ethiopia', GIEWS, www.fao.org/giews/countrybrief/country.jsp?code=ETH (accessed 14 September 2015)

Global Information and Early Warning System (GIEWS) (2015c) 'GIEWS Country Brief: Guatemala', GIEWS, www.fao.org/giews/countrybrief/country.jsp?code=GTM (accessed 14 September 2015)

Global Information and Early Warning System (GIEWS) (2015d) 'GIEWS Country Brief: Kenya', GIEWS, www.fao.org/giews/countrybrief/country.jsp?code=KEN (accessed 14 September 2015) 
Global Information and Early Warning System (GIEWS) (2015e) 'GIEWS Country Brief: Vietnam', GIEWS, www.fao.org/giews/countrybrief/country.jsp?code=VNM (accessed 14 September 2015)

Global Information and Early Warning System (GIEWS) (2015f) 'GIEWS Country Brief: Zambia', GIEWS, www.fao.org/giews/countrybrief/country.jsp?code=ZMB (accessed 14 September 2015)

Global Information and Early Warning System (GIEWS) (2014a) 'GIEWS Country Brief: Bolivia', GIEWS, www.fao.org/giews/countrybrief/country.jsp?code=BOL (accessed 14 September 2015)

Goody, Jack (1997) 'Industrial Food: Towards the Development of a World Cuisine', in Carole Counihan and Penny Van Esterik (eds), Food and Culture: A Reader, New York NY:

Routledge

Harris, Gina (2014) 'Unpacking Dietary Inequalities: Food Shopping, Mothers, Money and Morals', PhD thesis, Deakin University

Hossain, N.; King, R. and Kelbert, A. (2013) Squeezed: Life in a Time of Food Price Volatility, Year 1 Results, Oxfam Research Reports, Oxford: Oxfam GB

International Food Policy Research Institute (IFPRI) (2014a) '2014 Nutrition Country Profile: Bangladesh', IFPRI, http://globalnutritionreport.org/files/2014/11/gnr14_cp_bangladesh.pdf (accessed 14 September 2015)

International Food Policy Research Institute (IFPRI) (2014b) '2014 Nutrition Country Profile: Bolivia', IFPRI, http://globalnutritionreport.org/files/2014/11/gnr14_cp_bolivia.pdf (accessed 14 September 2015)

International Food Policy Research Institute (IFPRI) (2014c) '2014 Nutrition Country Profile: Burkina Faso', IFPRI, http://globalnutritionreport.org/files/2014/11/gnr14_cp_burkina_faso.pdf (accessed 14 September 2015)

International Food Policy Research Institute (IFPRI) (2014d) '2014 Nutrition Country Profile: Ethiopia', IFPRI, http://globalnutritionreport.org/files/2014/11/gnr14_cp_ethiopia.pdf (accessed 14 September 2015)

International Food Policy Research Institute (IFPRI) (2014e) '2014 Nutrition Country Profile: Guatemala', IFPRI, http://globalnutritionreport.org/files/2014/11/gnr14_cp_guatemala.pdf (accessed 14 September 2015)

International Food Policy Research Institute (IFPRI) (2014f) '2014 Nutrition Country Profile: Kenya', IFPRI, http://globalnutritionreport.org/files/2014/12/gnr14_cp_kenya.pdf (accessed 14 September 2015)

International Food Policy Research Institute (IFPRI) (2014g) '2014 Nutrition Country Profile: Indonesia', IFPRI, http://globalnutritionreport.org/files/2014/11/gnr14_cp_indonesia.pdf (accessed 14 September 2015)

International Food Policy Research Institute (IFPRI) (2014h) '2014 Nutrition Country Profile: Pakistan', IFPRI, http://globalnutritionreport.org/files/2014/12/gnr14_cp_pakistan.pdf (accessed 14 September 2015)

International Food Policy Research Institute (IFPRI) (2014i) '2014 Nutrition Country Profile: Vietnam', IFPRI, http://globalnutritionreport.org/files/2014/12/gnr14_cp_viet_nam.pdf (accessed 14 September 2015) 
International Food Policy Research Institute (IFPRI) (2014j) '2014 Nutrition Country Profile: Zambia', IFPRI, http://globalnutritionreport.org/files/2014/11/gnr14_cp_zambia.pdf (accessed 14 September 2015)

Kelly, Bridget; Halford, J.C.; Boyland, E.J.; Chapman, K.; Bautista-Castaño, Inmaculada; Berg, Christina and Caroli, Margherita et al. (2010) 'Television Food Advertising to Children: A Global Perspective', American Journal of Public Health 100.9: 1730-36

King, R.; Kelbert, A.; Chisholm, N. and Hossain, N. Help Yourself! Food Rights and Responsibilities. Year 2 Findings from Life in a Time of Food Price Volatility, Oxford and Brighton: Oxfam and IDS

Laudan, Rachel (2013) Cuisine and Empire, Oakland CA: University of California Press

Laudan, Rachel (2001) 'A Plea for Culinary Modernism: Why We Should Love New, Fast, Processed Food', Gastronomica 1.1: 36-44

Lobstein, Tim; Jackson-Leach, Rachel; Moodie, Marjory L.; Hall, Kevin D.; Gortmaker, Steven L.; Swinburn, Boyd A.; James, W Philip T.; Wang, Youfa and McPherson, Klim (2015) 'Child and Adolescent Obesity: Part of a Bigger Picture', The Lancet 385.9986: 2510-20

McCann, James (2001) 'Maize and Grace: History, Corn, and Africa's New Landscapes, 1500-1999', Comparative Studies in Society and History 43.2: 46-72

Monteiro, Carlos A.; Gomes, Fabio S. and Cannon, Geoffrey (2010) 'The Snack Attack', American Journal of Public Health 100.6: 975-81

Mwangi, Alice Mboganie, den Hartog, Adel P.; Foeken, Dick W.J.; van't Riet, Hilda; Mwadime, Robert K.N. and Van Staveren, Wija A. (2001) 'The Ecology of Street Foods in Nairobi', Ecology of Food and Nutrition 40.5: 497-23

Nestlé (2015) 'Nestlé Helps Address Micronutrient Deficiency in Africa with New Maggi Cube', www.nestle.com/media/newsandfeatures/iron-fortified-maggi (accessed 11 May 2015)

Nestle, Marion (2013) 'FDA Study: Do Added Nutrients Sell Products? (Of Course They Do)', Food Politics, www.foodpolitics.com/2013/08/fda-study-do-added-nutrients-sell-products-ofcourse-they-do/ (accessed 15 September 2015)

Patel, Raj (2012) Stuffed and Starved: The Hidden Battle for the World Food System, 2nd ed., Brooklyn NY: Melville House

Pelto, Gretel H. and Pelto, Pertti J. (1983) 'Diet and Delocalization: Dietary Changes since 1750', The Journal of Interdisciplinary History 14.2: 507-28

Ploeg, Jan Douwe van der (2010) 'The Food Crisis, Industrialized Farming and the Imperial Regime', Journal of Agrarian Change 10.1: 98-106

Pollan, Michael (2007) The Omnivore's Dilemma: A Natural History of Four Meals, Lrg ed., Waterville ME: Large Print Press

Popkin, Barry M. (2001) 'The Nutrition Transition and Obesity in the Developing World', The Journal of Nutrition 131.3: 871S-873S

Provost, Claire and Jobson, Elissa (2014) 'Move over Quinoa, Ethiopia's Teff Poised to Be next Big Super Grain', The Guardian, www.theguardian.com/global-

development/2014/jan/23/quinoa-ethiopia-teff-super-grain (accessed 15 September 2015)

Raschke, Verena and Cheema, Bobby (2008) 'Colonisation, the New World Order, and the Eradication of Traditional Food Habits in East Africa: Historical Perspective on the Nutrition Transition', Public Health Nutrition 11.07: 662-74 
Robson, J.R.K. (1976) 'Commentary: Changing Food Habits in Developing Countries', Ecology of Food and Nutrition 4.4: 251-56

Rozin, Paul (2007) 'Food and Eating', in Shinobu Kitayama and Dov Cohen (eds), Handbook of Cultural Psychology, New York NY: Guilford Press

Rozin, Paul (2005) 'The Meaning of Food in Our Lives: A Cross-Cultural Perspective on Eating and Well-Being', Journal of Nutrition Education and Behavior 37, Supplement 2 (November): S107-12

Rozin, Paul (2002) 'Human Food Intake and Choice: Biological, Psychological and Cultural Perspectives', in H. Anderson, J. Blundell and M. Chiva (eds), Food Selection: From Genes to Culture, Paris: Danone Institute

Stuckler, David and Nestle, Marion (2012) 'Big Food, Food Systems, and Global Health', PLoS Med 9.6: e1001242

UNICEF, WHO and World Bank (2014) Joint Child Malnutrition Estimates, http://data.unicef.org/nutrition/malnutrition\# (accessed 21 September 2015)

World Bank (2014) 'Food Price Watch', September 2014, World Bank, www.worldbank.org/en/topic/poverty/publication/food-price-watch-september-2014 (accessed 14 September 2015)

World Food Programme (WFP) (n.d.), 'The Market Monitor', World Food Programme, www.wfp.org/content/market-monitor (accessed 14 September 2015)

World Food Programme (2014a) 'The Market Monitor', Issue 23, April 2014, World Food Programme, http://documents.wfp.org/stellent/groups/public/documents/ena/wfp264521.pdf (accessed 14 September 2015)

World Food Programme (2014b) 'The Market Monitor', Issue 24, August 2014, World Food Programme, http://documents.wfp.org/stellent/groups/public/documents/ena/wfp266806.pdf (accessed 14 September 2015)

World Food Programme (2014c) 'The Market Monitor', Issue 25, October 2014, World Food Programme, http://documents.wfp.org/stellent/groups/public/documents/ena/wfp268848.pdf (accessed 14 September 2015)

World Food Programme (2014d) ‘Bangladesh Food Security Monitoring Bulletin', Issue 17, April-June 2014, World Food Programme, http://documents.wfp.org/stellent/groups/public/documents/ena/wfp267309.pdf (accessed 14 September 2015)

World Food Programme (2014e) 'Bangladesh Food Security Monitoring Bulletin', Issue 18, July-September 2014, World Food Programme,

http://documents.wfp.org/stellent/groups/public/documents/ena/wfp270174.pdf (accessed 14 September 2015)

World Food Programme (2014f) 'Pakistan Food Security Bulletin', Issue 2, December 2014, World Food Programme, http://documents.wfp.org/stellent/groups/public/documents/ena/wfp271228.pdf (accessed 14 September 2015)

World Food Programme (2014g) 'Ethiopia Monthly Market Watch, October 2014', World Food Programme, http://documents.wfp.org/stellent/groups/public/documents/ena/wfp269955.pdf (accessed 14 September 2015) 
World Food Programme (2014h) 'The Market Monitor', Issue 25, October 2014, World Food Programme, http://documents.wfp.org/stellent/groups/public/documents/ena/wfp268848.pdf (accessed 14 September 2015)

World Food Programme (2014i) 'Global Food Security Update', Issue 16, December 2014, World Food Programme,

http://documents.wfp.org/stellent/groups/public/documents/ena/wfp270716.pdf (accessed 14 September 2015)

World Food Programme (2014j) ‘Pakistan Market Price Bulletin', December 2014, World Food Programme, http://documents.wfp.org/stellent/groups/public/documents/ena/wfp271606.pdf (accessed 14 September 2015)

World Food Programme (2013) 'Bangladesh Food Security Monitoring Bulletin', Issue 14, July-September 2013, World Food Programme,

http://documents.wfp.org/stellent/groups/public/documents/ena/wfp260543.pdf (accessed 14 September 2015)

Zerbe, Noah (2004) 'Feeding the Famine? American Food Aid and the GMO Debate in Southern Africa', Food Policy 29.6: 593-608 


\section{ACKNOWLEDGEMENTS}

Bangladesh : Ferdous Jahan, Sharif A Wahab, Md. Mamun-ur-rashid, Omar Faruq Siddique, Shameem Reza Khan, Nahid Hasan, Muhammad Hedayet Hussain, Sanjida Hossain, Md. Mamun ur Rashid, Md. Moniruzzaman, Muhd. Naimul Amin, Raju Ahammed, Arif Rahman, Md. Mahbub Hasan, Meraz Ahmed, Md. Ali Newez Khan, Md. Sohel Rana

Bolivia : Rosario Leon, Jean Paul Benavides, Blanca León, Jose Luis Barroso, Jauregui Gilda, Pedro Badran, ; Field facilitator : Eduarda Cabrera.

Burkina Faso : Ludovic Kibora, Bambara Awa Carole, Dayamba K. Francis, Mando Guibril, Segda Ablassé, Ouédraogo Soulheiman, Sawadogo Marie, Ouedraogo Honorine

Ethiopia: Tassew Woldehanna and Yisak Tafere; Field Researchers, Asmeret Gebrehiwet, Kiros Berhanu, Workneh Abebe, Tefera Goshu and Abraham Alemu.

Guatemala: Alma Lucrecia Olivet López, with the support of Margarita Ramirez, Jennifer López, Fernando Coc Macú, Jerson Estuardo López and Mishelle Olivet; Field facilitators Ingrid Bocel, Cruz Elena Morales, Marvin Lotzoj, Tomasa Eugenia Morales and Micaela Sut. Addditional support form Luis Paíz-Becker and Gabriela Alcatráz. Special thanks to René Morales.

Indonesia: Rachma Indah Nurbani, Bambang Sulaksono, Hariyanti Sadaly, Mayang Rizky, Hafiz Arfyanto, Nur Aini, and Muhammad.

Kenya: Carolyne Gatimu, Nathaniel Kabala, Diana Ndung'u, Keziah Mumbi and Peter Kimani

Pakistan: Haris Gazdar, Hussain Bux Mallah and Ayesha Mysorewala; field investigators - Hussain Bux Mallah, Hassan Zaib Abbasi, IIma Ghouse, Ayesha Mysorewala, and Ayesha Tarek

Vietnam : Tran Cong Thang, Dinh Bao Linh, Vu Huy Phuc

Zambia : Mwila Mulumbi, Harold Mukupa, Kabuswe Chikoti, Kabuswe Chikoti, and Estone Phiri. Regina Mubanga, Jose ph Chikwanda in Chikwanda, and Gift Mataa in Kabwata supported the research process and provided monthly 'listening' updates. 
This report is co-published by the Institute of Development Studies and Oxfam International. IDS and Oxfam cannot be held responsible for errors or any consequences arising from the use of information contained in this report. The views and opinions expressed are those of the authors and do not necessarily reflect those of IDS or Oxfam policy positions.

(C) Institute of Development Studies and Oxfam International October 2015

This publication is copyright but the text may be used free of charge for the purposes of advocacy, campaigning, education, and research in non-commercial outputs, provided that the source is acknowledged in full. The copyright holder requests that all such use be registered with them for impact assessment purposes. Readers are encouraged to reproduce material from the report, but copying for any circumstances other than those listed above, or for re-use in other publications/translation or adaptation, permission must be secured. E-mail G.Edwards@ids.ac.uk.

The information in this publication is correct at the time of going to press.

Published by the Institute of Development Studies under ISBN 978-1-78118-279-6 in October 2015.

\section{OXFAM}

Oxfam is an international confederation of 17 organizations networked together in 94 countries, as part of a global movement for change, to build a future free from the injustice of poverty. For further information, visit www.oxfam.org

\section{IDS}

The Institute of Development Studies (IDS) is a leading global institution for development research, teaching and learning, and impact and communications, based at the University of Sussex. For further information, visit www.ids.ac.uk
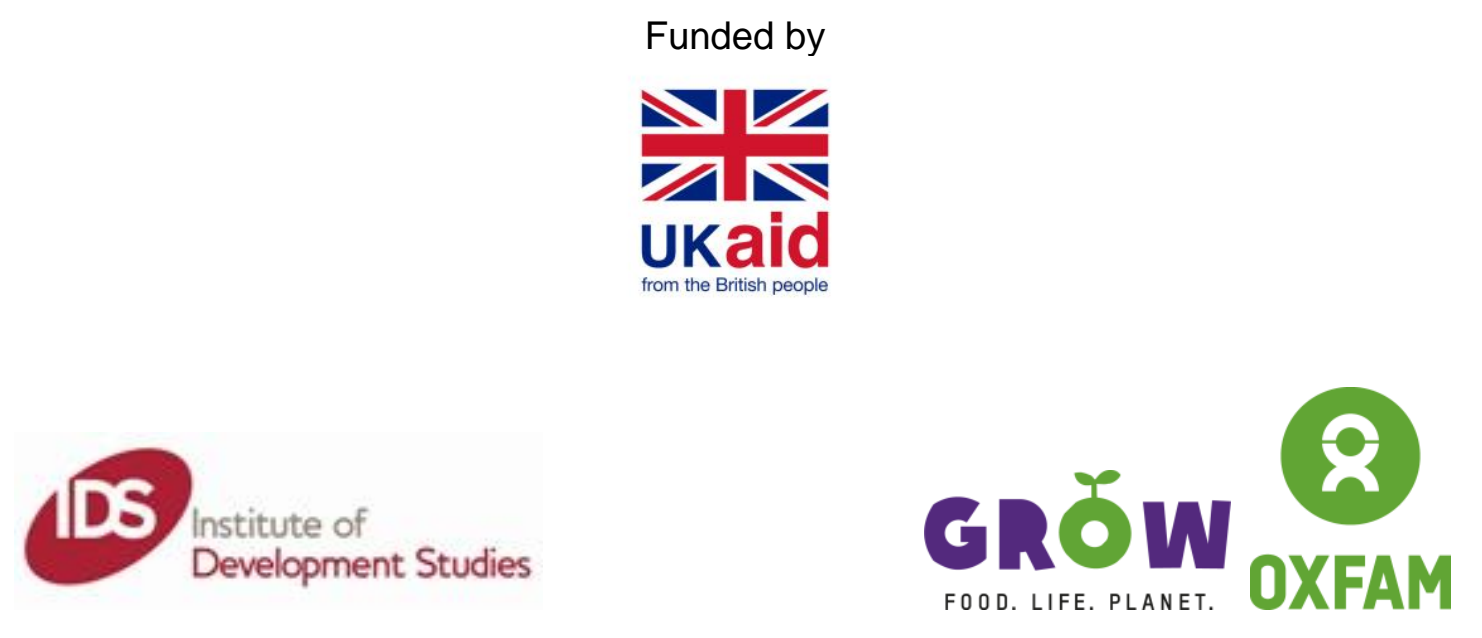

www.ids.ac.uk

www.oxfam.org 